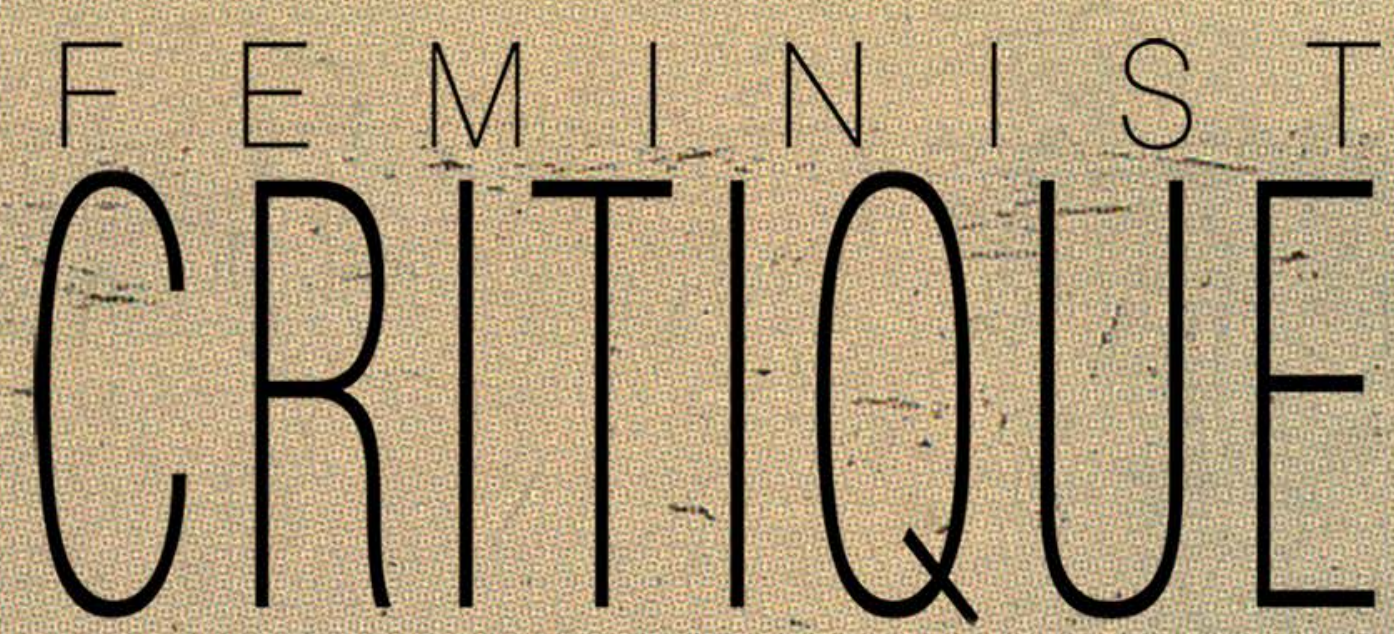

EAST EUROPEAN JOURNAL,OF FEMINIST AND QUEER STUDIES

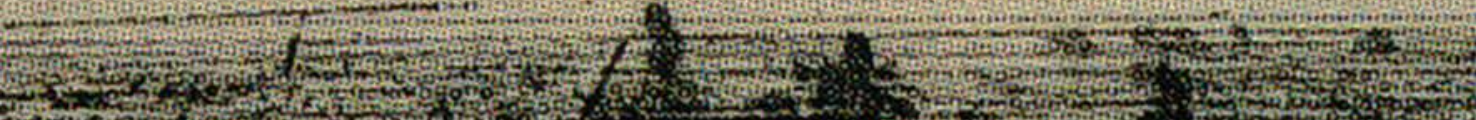

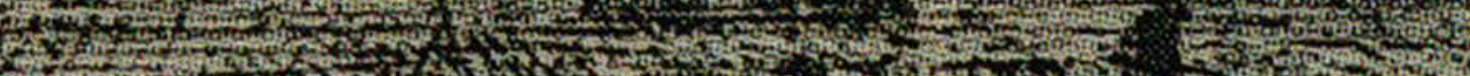

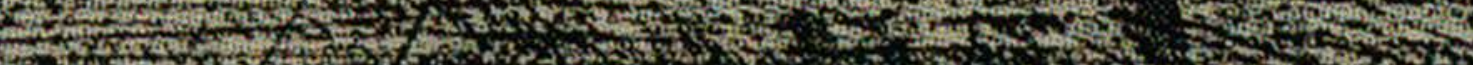
(6) X.t.

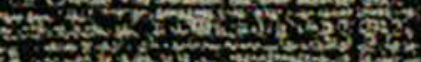
Eis

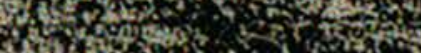

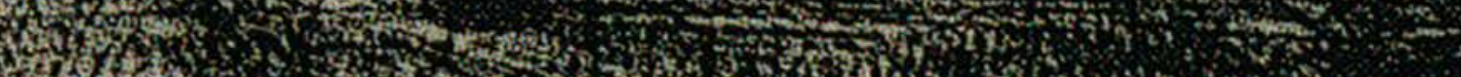

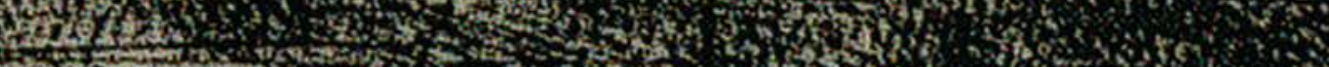
作

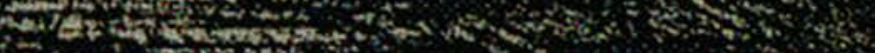

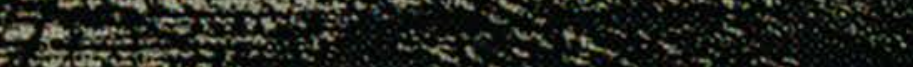
6.

Yow

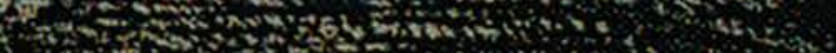

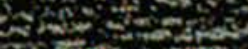

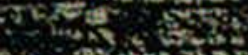

ag

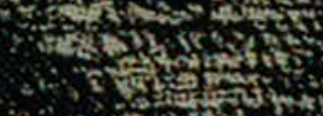

A. 5 s

S. W : t

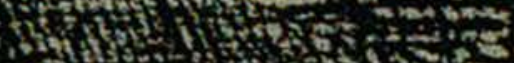

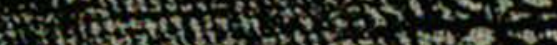
(2)

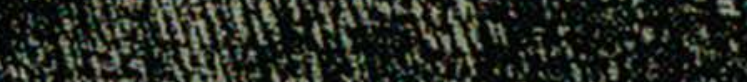
44 sts

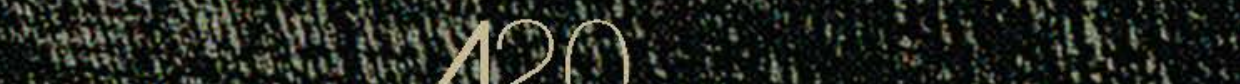
2.

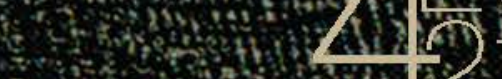

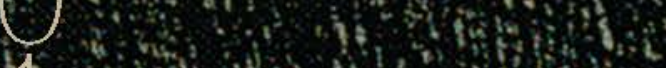
(3) 


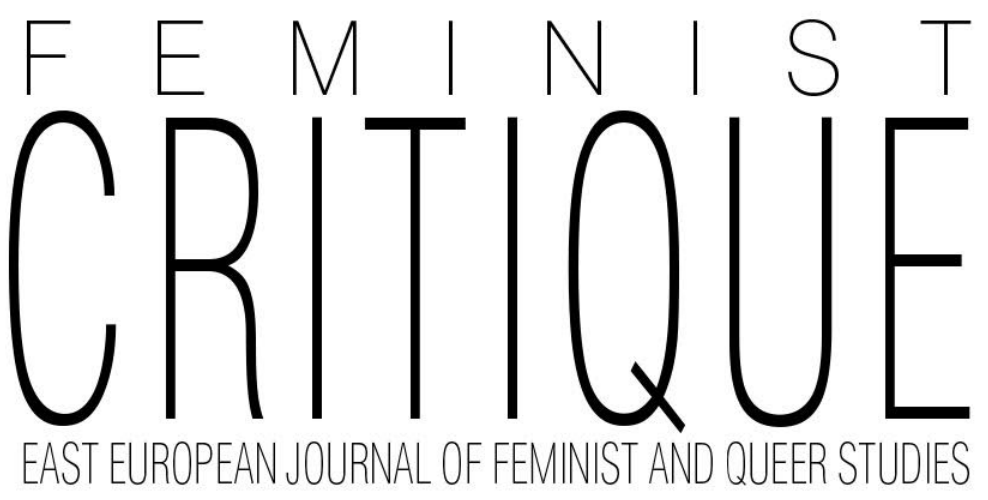

\author{
Special Issue \\ Queer and Feminist Studies \\ in Eastern Europe
}

\title{
Editors in Chief
}

Maria Mayerchyk \& Olga Plakhotnik

\section{Guest Editors}

Ramona Dima \& Simona Dumitriu

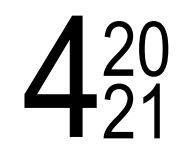


ISSN 2524-2733

DOI: https://doi.org/10.52323/fc4

Критика феміністична: східноєвропейский журнал феміністичних та квір-студій - науковий рецензований онлайн-журнал вільного доступу, що публікує тексти українською, англійською і російською мовами.

Feminist Critique: East European Journal of Feminist and Queer Studies is a scholarly peer-reviewed open access online journal that publishes materials in Ukrainian, English, and Russian.

\section{Editorial Board}

Ержебет Борат

Олена Боряк

Маруся Боцюрків

Віталій Чернецький

Сара Кровлі

Славенка Дракуліч

Алена Гапава

Джек Галберстам

Олександра Грицак

Туула Ювонен

Аді Кунцман

Оксана Луцишина

Ніна Люке

Йоана Мізєліньска

Альміра Усманова

Андреа Пето

Маргріт Шилдрік

Кері Сміт

Дженіфер Сачленд

Сюзан Талбурт

Анна Темкина

Елізабет Вуд

Адријана Захаријевић

Елена Здравомыслова

Ірина Жеребкіна

Тетяна Журженко
Erzsébet Barát | Central European University

Olena Boriak | Центр культурно-антропологічних студій

Marusya Bociurkiw | Ryerson University

Vitaliy Chernetsky | University of Kansas

Sara Crawley | University of South Florida

Slavenka Drakulić | Independent writer

Elena Gapova | Western Michigan University

Jack Halberstam | Columbia University

Alexandra Hrytsak | Reed College

Tuula Juvonen | Tampereen yliopisto

Adi Kuntsman, Manchester Metropolitan University

Oksana Lutsyshyna | University of Texas

Nina Lykke | Linköping universitet

Joanna Mizielińska | Polska Akademia Nauk

Almira Ousmanova | Europos humanitarinis universitetas

Andrea Pető | Central European University

Margrit Shildrick | Linköping universitet

Carrie Smith | University of Alberta

Jennifer Suchland | Ohio State University

Susan Talburt | Georgia State University

Anna Temkina | Европейский университет в Санкт-Петербурге

Elizabeth Wood | Massachusetts Institute of Technology

Adriana Zaharijević | Универзитет у Београду

Elena Zdravomyslova | Европейский университет в Санкт-Петербурге

Irina Zherebkina | Харківський національний університет ім. В. Каразіна

Tetyana Zhurzhenko | Universität Wien 
Website: http://feminist.krytyka.com

Email address: feminist@krytyka.com

Editorial mailing address: P.0. Box 225, 01001 Kyiv, Ukraine

ISSN 2524-2733

https://doi.org/10.52323/fc4

This special issue of the Feminist Critique is partially funded by the Canadian Institute of Ukrainian Studies and the RFSL (Swedish Federation for Lesbian, Gay, Bisexual, Transgender, Queer and Intersex Rights) "Resilient Movements, Stronger Communities" program. The funding institutions are not responsible for the content of the articles.

Цей спецвипуск журналу Критика феміністична підготовано за часткової фінансової підтримки Канадського інституту українських студій і програми Шведської федерації за права ЛГБТКI+ RFSL, програма "Стійкі рухи, сильніші громади". Грантодавчі інституції не несуть відповідальність за зміст текстів.

\author{
Managing Editor Zaryana Lysytsya \\ Graduate Research Lesia Pagulich, Tatsiana \\ Assistants Shchurko, Vanya Solovey \\ Krytyka Editor Oleh Kotsyuba \\ Copy Editor Kate Rudyk \\ Website Assistant Anna Stepanova \\ Cover Design Valentina Petrova \\ Layout Setting Iryna Sobko
}

Redistribution of the Feminist Critique materials is permitted, provided that the reference to the Feminist Critique appears and the purpose of reprinting is non-commercial.

Any commercial use of the publications or their parts is prohibited.

Поширення публікацій сайту та журналу Критика феміністична дозволено за умови покликання на Критику феміністичну і тільки з некомерційною метою.

Будь-які комерційні дії з текстами чи їх частинами заборонено.

Cover: a fragment of the "View of Quarry" artwork by Latvian American artist Vija Celmins (1962).

Обкладинка: фрагмент роботи латвійсько-американської художниці Вії Целмінч “Вид на кар'єр” (1962). 



\section{Contents}

A Note from the Guest Editors.

\section{Статті • Articles • Статьи}

Aia Beraia

Hegemony in Post-Soviet Georgia: Types of Nationalisms

and Masculinitie

Ван я Соловей

Чей феминизм? Феминистские движения в России и «западная культурная гегемония»

Anna Carastathis

"Racism" versus "Intersectionality"? Significations of Interwoven

Oppressions in Greek LGBTQ+ Discourses?

Myrto Tsilimpounidi

Queering Bratislava: On Borders, Otherness and Public Space

Rita Béres-Deák

Same-sex Parenting Practices in Hungary as an Assertion of Intimate

Citizenship

\section{Переклад • Translation • Перевод}

Ержбет Борат

Переклад : Надія Чушак

Стигматизація аналітичної концепції ґендеру як ідеології

\section{Рецензії • Reviews • Рецензии}

0 ксана Дудко

Некрополітика, гомонаціоналізм і вразливі квір-життя в часи глобального неолібералізму

Оксана Гусєва

Жити феміністично

Ганна Гнедкова

«Наші Дикі»: естетика та політика в музиці незалежної України

About the Contributors 



\section{A Note from the Guest Editors}

Queer and Feminist Studies in Eastern Europe (QueerFemSEE) International Conference took place in 2017 in Bucharest, bringing together around 40 participants from Central and South Eastern Europe who shared their valuable research and experiences in an oddly modern conference hall in one of the buildings belonging to the Faculty of Sociology, University of Bucharest. The conference was organised on a very small budget, an ERSTE grant of 4000 euro, which were directed toward covering travel expenses for more than half of QueerFemSEE's participants as well as accommodation for even more. Every bit of organisational and communication work was done through volunteer engagement by us as well as by several other persons from our kinship circles. We will forever be indebted to them.

QueerFemSEE was the first ever conference intersecting activism, queer studies and overall queer humanities with a focus on SEE taking place in Romania, and most importantly so, taking place within the biggest public Romanian university, the University of Bucharest. For us this was the goal: to push through the walls of the homophobia and elitism sometimes encountered in the public university and hold QueerFemSEE inside those revered, dusty walls. At that moment, Ramona was a student of the Doctoral School in Communication Sciences, and indeed several of the professors active there did support her initiative, including her doctoral coordinator. Yet not all were onboard, as one of the doctoral school coordinators tried to transform the conference from a three-day event (for which over 120 contribution proposals were received) into a half a day "internal" round table to which participants, instead of receiving travelling funds, would supposedly pay to attend. As we stood our ground, she refused on behalf of the Doctoral School to host the conference. We started to knock at other University doors, and finally, the Faculty of Sociology offered us a modern conference room in the University's newer campus, located somewhere by the outer edge of Bucharest's semi-centre.

We put together detailed walkthroughs to guide everyone in a not tourist-friendly city. We loaned big stainless steel serving dishes from a friend who owned a restaurant; e-mailed everyone, as much as needed. Marvelled at how many people were keen to walk the streets of Bucharest and make queer history. Felt grateful that so many managed to get grants from their own institutions and cover their own expenses, leaving us room to cover as much as possible for the others' arrival and stay. Bought heavy bags of food from supermarkets and markets, a water heater and a really lovely, big conference thermos. Drafted menus, while editing the book of abstracts and designing the poster and logo. Lurked extensively around the conference venue, figur- 
ing out any safety issues and making sure that we would be as safe as possible from right-wingers. And finally we cooked copious amounts of food (our friends and mothers helped too) to cater to about 70 people for lunches and dinners, since we knew we had no money for nice restaurant outings. Made endless pots of coffee, while listening to the speakers and feeling that the conference needed to continue and establish itself with some form of frequency.

At that point Olga Plakhotnik's invitation came: to collaborate for a special issue of Feminist Critique Journal, that would include the conference's proceedings. We embarked on the task of contacting and inviting the conference participants to submit papers, while our own lives took an unexpected turn: Simona got a job as a curator at a gallery in Malmö, Sweden's third largest city. Even though her salary was just enough to cover rent and some food, prospects were lesser in Bucharest, where we had done so much unpaid work yet no doors were opening for paid employment, so we packed 150 kilos of belongings in a long distance bus. Then returned, took the cat and flew to Malmö. In different ways, leaving Romania was our right choice, but pushed us into a whirlwind of adaptation, looking for jobs, more work without pay, moving from one rental apartment to another, until we managed to somewhat find balance. It also pushed us onto the epistemological spot of the diaspora - of those who left - leaving us to wonder, to this day, how one negotiates new queer positions in a so-called post-queer North-Western European society, and how should we relate to the work and the struggles back home, when home itself is a territory of doubt.

More than two years have passed, and the QueerFemSEE proceedings moved ever so slowly ahead, with gaps in communication, waves of change and efforts of adaptation. We now know that a second edition of the conference will have to take place here, in this North-West, and possibly delve deep into how queer researchers and academics from the SEE, now based in the West, still relate and research into countries they are distant to. And what do territoriality, identity and queer diasporas mean especially now, when facing a war against gender issues in both SEE and CEE.

With this special issue, we are preparing the path, and looking into topics such as: nationalisms and masculinities in the recent history of Georgia analyzed in Aia Beraia's article; how "Western" cultural hegemony functions with regards to feminism and the various ways to critically interact with it (Vanya Solovey's contribution); the relation between "intersectionality" and racism in Greek LGBTQ+ activists' discourses explored by Anna Carastathis; Myrto Tsilimpounidi's research on the possibilities of queering (post-socialist) spac$e s$, an analysis centered on Bratislava; the legislative and social obstacles that Hungarian LGBTQ families face within the heteronormative framework of the state (Rita Béres-Deák).

The conference and the proceedings have brought forth several relevant topics which form the fundamental basis of queer CEE and SEE research, or research-fused activism. Thus, the "West" is acknowledged as an epistemological and political category still relevant 30-plus years after the symbolical fall of the Berlin Wall, and one with particular relevance to queer research in 
the "East". While much of the understanding of gender and sexuality topics in the "East" has been constructed on the basis of "Western" understanding of those similar words and ideas, there is a polyphony of contexts and experiences within various nation-states or regions in the CEE and SEE which demand critical questioning of this "Western"-based buildup of notions. There are ever more intricate relationships between nationalism, national and ethnical identities, religion and history in the "East", with intersections of imperialisms that need their own tools of understanding and their own methodology - and this was and continues to be one of the aims and purposes of QueerFemSEE.

When Aia Beraia writes about "Hegemony in Post-Soviet Georgia: Types of Nationalisms and Masculinities", post-imperialist relationships with Russia and a relationship with the Western gaze surface. We do recognize types of masculinities and political affirmations of gender that are quite specific and regional, and can be extended even as far as Central Europe when we now try to understand the formation of anti- "Western", pro-tradition, neo-nationalist governments in countries as different as Poland, Hungary or Slovenia, or the perpetuity of such governments under different political parties in Romania, for instance.

Vanya Solovey's article, "Whose Feminism? Feminist Movements in Russia and "Western" Cultural Hegemony", critiques the perceived servitude of Russian feminism to "Western" feminism. In order to take a first step in the unlearning of "Western" feminism, Solovey's article is published in Russian. This does limit our access to the knowledge in the article, but, at the same time, nuances an important idea: there are many local-specific meanings and histories that may function as an alternative foundation to different, non-western-centric feminisms, which deny western access. We are thus left to question the cliché that, similarly, other CEE and SEE feminist practices are but a shadow or copy of a Western model.

Anna Carastathis's article, "Racism" versus "Intersectionality"? Significations of Interwoven Oppressions in Greek LGBTQ+ Discourses" delves into the analysis of how the term "racism" is used in queer Greek discourses to also mean "homophobia", so as an almost umbrella term for struggles based on considerations of race, ethnicity, citizenship as well as on considerations of gender identity and sexuality. Carastathis's text offers us an example of how local-specificity meets intersectional discourses, and how certain vocabularies of the oppressed are built and exist outside specific Western terminologies. From a Romanian activism and language standpoint, the vocabulary of oppressions is quite specific and does not overlap meaning, for instance, while both racism and homophobia intersect in the activism and literature of queer Roma persons.

Myrto Tsilimpounidi's contribution, "Queering Bratislava: On Borders, Otherness and Public Space", describes the author's arrival and effort to understand a city they had never visited before: a post-socialist capital city, located in the center of Europe, yet somehow invisible. The author encountered Bratislava in the "refugee summer" of 2015, when the city was still recovering from the (older) financial crisis of 2008. How does queer thought 
$\div$ engage a city made of fragments and references - to its post-communist past, to present day alienations - while equally referencing queer visibility in this type of public space? Such questions, and Tsilimpounidi's non-linear attempt at researching them, are applicable to any post-communist large city in the CEE and SEE, with its different and parallel sets of positionalities.

Finally, Rita Béres-Deák writes about "Same-sex Parenting Practices

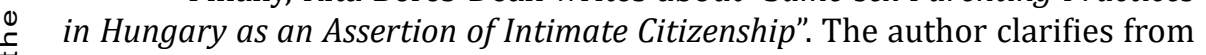
$\varepsilon$ the beginning that, while the sexual/intimate citizenship of LGBTQ persons is often discussed in North-American scholarship, not much focus is set on parenthood. Béres-Deák's six years study on same-sex couples raising children in $\stackrel{0}{\circ}$ Hungary represents a much needed contribution to the literature on parenting and intimate citizenship from a Central European point of view. The lack of parental rights recognition as a social parent, the struggles and activism in Hungary make us think about the nuances that intimate citizenship and parenthood have in countries without positive same-sex legislation, thus reframing ideas of family and kinship.

We would like to thank the contributors and peer reviewers for their excellent work, Olga Plakhotnik and Maria Mayerchyk together with their team at Feminist Critique Journal for their invitation and all their work, Vanya Solovey for providing Russian translations, Prof. Monica Spiridon for her support and guidance, as well as all our friends who helped making this project happen. 
Статті

○

Articles

-

Статьи 



\section{Hegemony in Post-Soviet Georgia: Types of Nationalisms and Masculinities}

\section{Introduction}

I

n Soviet Georgia, the political nationalist movement began in the 1980s. Its leaders aimed at establishing independence for Georgia and the formation of a Georgian state. The aim was finally achieved in 1991, during the collapse of the Soviet Union. This is the point when Georgia became an independent nation state (for the second time in Georgian history) and since then it has gradually transformed into a liberal democracy under neoliberal capitalism. In this process, post-Soviet Georgia moved away from the Soviet Union and its successor, Russia, and acquired European identity in both an economic and cultural sense.

These processes are reflected and generated through certain nationalist and masculinist discourses. As "the culture and ideology of hegemonic masculinity go hand in hand with the culture and ideology of hegemonic nationalism" (Nagel 1998), the aim of this article is to show what types of masculinities and nationalisms were and/or continue to be hegemonic in post-Soviet Georgia.

Todd W. Reeser claims that both masculinity and nationality "are being ideologically constructed" $(2010,177)$. He writes:

Discourse is central to these constructs: in the same way that definitions of male subjectivities are discursive, the nation is constructed in and through discourse and especially in political discourse (speeches, government documents, civics textbooks, etc.) $(2010,177)$.

Thus for the analysis of the discourses of hegemonic nationalisms and hegemonic masculinities, I chose seven persons from the political and economic elites of Georgia who were active during the years 1990-2016. Six of them occupied primary positions in the Georgian government. Discourses produced by them are of major importance as they are the chief faces and implementers of nationalist projects (see Jones 2006).

The article is written with the financial support of the Women's Fund in Georgia and based on the author's Master thesis "Nationalism and Hegemonic Masculinity in Post-Soviet Georgia" (2017). 
In this article, I will at first present concepts and theories that are the basis for the analysis followed by a brief discussion of the political history of post-Soviet Georgia. Then, I will present and interpret my findings about hegemonic masculinity and hegemonic nationalism in Georgia.

\section{Hegemony, Masculinity and Nationalism}

I will now analyze the concept of cultural and political hegemony, the concept and theory of hegemonic masculinity, the idea of a nation as the product of nationalism, and the theories that proclaim the connection between hegemonic nationalism and hegemonic masculinity.

Antonio Gramsci developed the concept of cultural and political hegemony in his Prison Notebooks (1992). He argues that ruling classes enact hegemony through civil society and state institutions. A bourgeois state is not solely based on repression, it also has "civilizing" function. This means that governance is mediated by educational, "civilizing" practices. State and civil society are educating and producing certain types of citizens by disseminating and propagating certain ideologies and types of subjectivity. Cultural and political hegemony means that ruling classes attain "consent" from the ruled, even though their governance is against the interests of the latter.

Consequently, nationalism as a cultural and political phenomenon can be viewed as a form of cultural and political hegemony: the state propagates nationalist ideas using public educational systems and media. These ideas are thus internalized by lower social classes. In this way, the nation state generates hegemonic nationalism and gains "consent" from the ruled.

As for hegemonic masculinity, R.W. Connell places this concept in her theory of masculinities (2005). She distinguishes four kinds of masculinities: hegemonic, complicit, subordinated, and marginalized. Connell defines hegemonic masculinity as, "the configuration of gender practice which embodies the currently accepted answer to the problem of the legitimacy of patriarchy, which guarantees (or is taken to guarantee) the dominant position of men and the subordination of women" $(2005,77)$. According to Connell, men who embody hegemonic masculinity are not always the most powerful people, and, what is more, the ideal of hegemonic masculinity can be represented by fantasy figures and characters rather than real men. However, there still has to be some kind of correspondence between this ideal and institutional power. Consequently, "the top levels of business, the military and government provide a fairly convincing corporate display of masculinity" (Connell 2005, 77). The public image of hegemonic masculinity holds up the power of masculine elites and is supported by the majority of men. Thus, hegemonic masculinity receives "consent" even from the marginalized or subordinated men. The major reason for this paradox seems to be that "most men benefit from the subordination of women, and hegemonic masculinity is the cultural expression of this ascendancy" (Connell 1991, 185). Another important feature of hegemonic masculinity is that "it is heterosexual, being closely connected to the institution of marriage; and a key form of subordinated masculinity is homosexual" (Connell 1991, 186). Despite offering these key universal features 
of hegemonic masculinity, Connell also mentions that hegemonic masculinity is not fixed and unchangeable and it can be contested (2005).

According to Benedict Anderson, nationality and nationalism are cultural artefacts of a particular kind. In his opinion, nationalism should not be treated as ideology, but as something that belongs with "kinship" and "religion" $(2016,5)$. Nationalism is a modern phenomenon, according to Anderson; it originated in Europe at the end of the XVIII century (2016). Nationalism replaced two cultural systems that had preceded it: the religious community and the dynastic realm. The decline of these two systems, as well as other social and economic changes occurring in Europe, created a need for a new order and new kinds of communities, "for a new way of linking fraternity, power and time meaningfully together" (Anderson 2016, 36). Nationalism gave birth to the idea of the nation. The nation is defined by Anderson as "an imagined political community - and imagined as both inherently limited and sovereign" $(2016,6)$. A nation is imagined because it is impossible for all members of a nation to know or meet each other; therefore, their communion is illusory (ibid.). A nation is limited because it is always imagined with borders and is never coterminous with mankind $(2016,7)$. "Finally, it is imagined as a community, because regardless of the actual inequality and exploitation that may prevail in each, the nation is always conceived as a deep, horizontal comradeship" (ibid.).

Anderson also discusses print-capitalism, which contributed greatly to the creation of nationalism and "imagined communities" (2016). The emergence of print-capitalism from the sixteenth century onwards meant the ascendency of vernacular languages (instead of Latin) and the mass production and consuming of books and newspapers in Europe. Print-capitalism created the basis for national consciousness via the following: (a) through creating a unified field of communication as language was becoming more "universal" and comprehensible for all speakers who were also becoming aware of their "fellow-readers"; and (b) through giving fixity to language, which later helped to create the image of its (and therefore the nation's) antiquity $(2016,44)$.

Similarly, Etienne Balibar writes about the crucial role of language in producing ethnicity; however, he also adds that there is a "correlation between the national formation and development of schools as "popular" institutions," because of the role they play in the socialization of individuals $(2010,97)$. He emphasizes that "schooling is the principal institution which produces ethnicity as a linguistic community" $(2010,98)$.

Balibar also claims that the ideological form that is necessary in order to create "people" and "nationalize" individuals would be called nationalism or patriotism, and that it is originated by political methods, such as "the combination of 'force' and 'education' (as Machiavelli and Gramsci put it)" (2010, 95). ${ }^{1}$ He partially agrees with the idea that, nonetheless, the deepest reason of nationalism's or patriotism's effectiveness lies in the notion that they are the religion of modern times (ibid.). According to Balibar, national identity is not a simple analogy of religious identity, but it also tends to integrate and replace the latter (ibid.).

${ }^{1}$ Here we have the reference to Gramsci and the concept of hegemony. 
Thus, we can see that both masculinity and nationality are socially constructed and both can become hegemonic. In the case of nationalism, theorizing about the role of printed materials, media, and public education system gains importance as they are also crucial elements for sustaining hegemony. Now we can draw attention to the next issue: how do hegemonic nationalism and hegemonic masculinity relate to each other?

Modern forms of masculinity are historically related and intertwined with the nation state and nationalism. Joane Nagel writes that "the modern forms of Western masculinity emerged at about the same time and place as modern masculinity" $(1998,249)$. Masculinity has been defining and dominating modern political systems in various ways. According to Nagel, "the national state is essentially a masculine institution," as men traditionally dominate the decision-making positions and ensure the subordination of women through hierarchical authority structure $(1998,251)$. She also cites Cynthia Enloe, according to whom nationalist ideologies relegate women to minor and often symbolic roles. On the other hand, "the real actors are men who are defending their freedom, their honour, their homeland and their women" (Nagel 1998, 244). Todd W. Reeser is another scholar who focuses on the fact that nationalism and the nation state has been dominated by men. Leaders of nations have mostly been men, and their gender and sexuality has been crucial for the image of the nation. Thus, the prestige of the nation is based on its association with masculinity and heterosexuality. As previously mentioned, both nationality and masculinity are ideologically and discursively constructed: "in the same way that definitions of male subjectivities are discursive, the nation is constructed in and through discourse and especially in political discourse (speeches, government documents, civics textbooks, etc.)" (Reeser 2010,177). Nation/nationality and gender/masculinity support each other culturally and help to make each other appear natural. They overlap, influence, and mutually construct each other in such a way that it becomes very difficult to discern which is the original and primary force in the society. "[T] he nation creates masculinity at the same time as masculinity creates the nation" (Reeser 2010, 178).

Using the example of post-Soviet Georgia, I will briefly discuss the functioning of hegemonic nationalism and hegemonic masculinity in this context. The decision-making positions of the Georgian nation state are dominated by men - the institutional leaders of the nation, such as presidents and prime ministers have all been men. ${ }^{2}$ Parliament is dominated by men as well, as only $16 \%$ of the MPs are women. However, this is the highest percent in the history of post-Soviet Georgia. The representation of women in parliament was especially low in the first decade of independence: $6.22 \%$ in $1992,6.64 \%$ in 1995 , and 7.17\% in 1999 (Netgazeti 2016). In order to increase women's representation, the feminist movement in Georgia initiated a law about obligatory gender quotas in political parties; however, the recent version of this law was rejected by the parliament in March 2018.

${ }^{2}$ During the writing of this article, in November 2018, a first female president, Salome Zurabishvili, was elected. 
While men are the decision-makers and main actors of the nation, in some versions of nationalism woman(hood) has been relegated to serve as a national symbol. The statue of Kartlis Deda (Mother of Georgia) erected in Tbilisi serves as good example of this phenomenon. In conservative nationalism, women were usually presented as mothers and loyal wives, while the public activities of women were not valued and the history of Georgian feminism was ignored. As for men, various versions of nationalism adopt the icon of a Georgian medieval king, David the Builder (1073-1125), under whose rule Georgia is said to have prospered. David the Builder is a popular figure; and perhaps because of this, some presidents of Georgia tried to associate themselves with him. For example, Mikheil Saakashvili visited David the Builder's tomb as a part of his inauguration ceremony in 2004. However, as neoliberal nationalism/masculinity has gradually become hegemonic ${ }^{3}$, attention to women's symbolic or traditional roles, as well as traditional masculine icons, such as David the Builder, have diminished. The new national heroes of this pro-Western nationalism are rich and powerful American men, such as George W. Bush, Donald Trump, and John McCain. In 2005, one of the streets in Tbilisi was given the name of George W. Bush, to symbolize the alliance between Georgia and the United States. In 2018, after Senator John McCain's death, there are also discussions in Georgia about naming streets after him in the country's cities.

To sum up, from the very beginning, nationalism and modern citizenship were created under male domination. Nationalism can be represented as a creation of men's homosocial unions. Consequently, it is no surprise that the leaders of the nation are mostly men. In nationalist ideologies, women occupy secondary and/or symbolic roles. The real actors of nationalism and the nation state are men - the main institution of nationalism is a masculine institution. Nationalism and the nation state provide men with institutional power. Institutional state power is used to create cultural hegemony and gendered projects, such as hegemonic masculinity.

\section{Political History of Post-Soviet Georgia}

I will briefly summarize the history of Post-Soviet Georgia. The history of independent Georgia till 2012 is told by Stephen F. Jones. His book, Georgia: A Political History since Independence (2013), covers the period of three presidents of Georgia - Zviad Gamsakhurdia, Eduard Shevardnadze and Mikheil Saakashvili.

Gamsakhurdia was one of the leaders of the Georgian nationalist movement that became active in the 1980s. After the first multi-party election in Soviet Georgia, Gamsakhurdia became the chairman of the Supreme Council of Georgia. After the announcement of independence in Georgia on April 9, 1991, he was elected as president. But his power was ended by the civil war

\footnotetext{
${ }^{3}$ Neoliberal masculinity is one of the hegemonic masculinities revealed by the analysis of discourses of the political and economic elites of post-Soviet Georgia and presented in this article, in the chapter, "Three Types of Hegemonic Masculinity."
} 
which broke out at the end of 1991, and the president was forced to leave the country. In the transitional period, power was taken by the military council, which soon invited Eduard Shevardnadze to rule. He was the former minister of foreign affairs of the Soviet Union, who then lived in Moscow. Shevardnadze arrived in Georgia in March 1992 and became the head of the transitional government. In the transitional period of 1992-1995, the government was trying to deal with war, chaos, and economic collapse throughout the country. In 1995, the Constitution of Georgia was approved by the parliament, and Shevardnadze was elected as president. This was the beginning of relative economic and institutional stabilization. Another period which brought major changes in the political and economic life of Georgia began in 2003, by the so-called Rose Revolution. Shevardnadze was forced to step down and the new leaders of the state became Mikheil Saakashvili (he was elected as president in 2004) and his party, the United National Movement. The new government introduced and enacted the policies of modernization, elimination of corruption, and economic liberalism, which was characterized by privatization and deregulation. These measures restricted citizens' access to education and healthcare, while their labor rights receded and they became more exposed to exploitation at the workplace. Altogether, these policies were the cause of increased social inequality (Jones 2013). Citizens became resistant to these policies while the state became more violent. This development was especially evident in the various crisis periods. Other historically important events were the war between Georgia and Russia in August 2008 and "the prison scandal" in 2012, which led to the defeat of Saakashvili's United National Movement in the election. Instead, the majority of seats in the Georgian parliament was won by Bidzina Ivanishvili's party, Georgian Dream. Bidzina Ivanishvili is a billionaire businessman. As a politician, he gained popularity by opposing Saakashvili's government. After the election in October 2012, he served as a prime minister of Georgia for one year. After the presidential election in 2013 he resigned, nevertheless, he is still believed to be the "informal leader" of the country by opposition parties and civil society in Georgia. In any case, the Georgian Dream initiated the constitutional reform, which restricted the rights of the president and gave more rights and duties to the prime minister. Since 2013, Georgia has an elected president as the head of state and a party-appointed prime minister as the head of government. Giorgi Margvelashvili of Georgian Dream was elected as a president in 2013. The new government has mostly continued the neoliberal policies introduced during Saakashvili's rule. However, Georgia signed and ratified the Association Agreement between Georgia and the European Union in 2014 and the document entered into force in July 2016. While Georgian citizens still suffer from poverty, human rights violations, and many forms of discrimination, the changed practices of governance and the agreement with the EU have affected Georgian citizenship and citizens' methods of resistance. Civil society actors such as NGOs and labor unions have become more actively engaged in the ongoing struggles alongside oppositional political parties.

Gamsakhurdia's period was defined by the issue of national independence, an anti-imperialist stance, and state autonomy. However, his nation- 
alism was becoming more and more isolationist until his rule was brought to end. Shevardnadze, on the other hand, underlined the importance of order, peace, unity, and consensus. Through diplomacy and maneuvering, he managed to maintain power. Saakashvili came into power as pro-Western progressist; nonetheless, his reforms increased social inequality and polarized society. The Georgian Dream government is less aggressive than Saakashvili and seems more open to critique and initiatives from political opposition and civil society. Nevertheless, no major changes have been introduced at the level of legislation and state practices.

This is the historical context in which the forms of hegemonic nationalism and hegemonic masculinity have emerged. Types of hegemonic masculinity and nationalism I discuss in the next sections become understandable in relation to this context, namely, the political and economic transformations which have great impact on the life of the nation.

\section{Three Types of Hegemonic Masculinity}

The tendencies in relations and overlapping between hegemonic nationalism and hegemonic masculinity can be studied by the analysis of public discourses (speeches, statements, interviews, etc.) of political and economic elites. First, I will focus on three types of hegemonic masculinity that are revealed in the discourses of the powerful Georgian men - presidents, prime ministers, politicians, and businessmen.

It is worth noting that in these elite discourses the ideas of nation and masculinity are often generated simultaneously. This is evident for example in Gamsakhurdia's, Saakashvili's, Bendukidze's, and Ivanishvili's texts. For these leaders, the liberation and development of the nation is connected with men. In their discourses, the nation is masculinized or is identified with men. Men are the faces and representatives of the nation on the global arena as well as at all levels of domestic and foreign affairs. The elites establish a connection between men/masculinity and the nation, which becomes evident in an analysis of the types of masculinities that they produce discursively.

The first type of masculinity that surfaces in this context is masculinity as a symbol of the nation and/or marker of cultural borders. This type of masculinity gains importance when discussing the independence of Georgia or when some actors feel that Georgian culture is threatened by empires and/or Westernization $^{4}$. Consequently, in certain versions of Georgian nationalism, men figure as the symbols of the nation - they are represented as having characteristics that make Georgians different from other nations. More specifically, men are supposed to embody or enact certain attributes such as morality, courage, and self-sacrifice. Some versions also claim that Georgian men lead a specific peasant lifestyle that is traditional and somehow natural for them. These are the cultural markers that make the nation unique and special, thus, in this version of nationalism/masculinity, men become the guardians of the nation's culture. The nation will live on if they stay loyal to these attributes and this kind of masculinity.

\footnotetext{
${ }^{4}$ In the studied data the "empires" are the Soviet Union, Russia and the USA/West.
} 


\section{Zviad Gamsakhurdia stated:}

The economic system in the captivity of the communist ideology and imposed violently on Georgian peasant has taken from him the most important things - land and freedom, and made work loathsome for him... Such an approach has negatively affected the character of Georgian man, his psyche and his traditional lifestyle (Gamsakhurdia 1991, 26).

This quote makes visible several things: (1) the nation is represented by men, (2) the peasant lifestyle is a national attribute of Georgians, and it was supposedly taken away from them by communists, (3) the terms "Georgian peasant" and "Georgian man" are used interchangeably, which strengthens the connection between nationalism and masculinity.

In 2005 Saakashvili speaks about Kakutsa Cholokashvili, a Georgian military officer who led the unsuccessful anti-Soviet rebellion in 1924. After the rebellion, he fled to France where he died in 1930. His remains were reburied in Georgia in 2005 during Saakashvili's rule. He was figured as a national hero and Saakashvili (2005) spoke at the funeral:

He was the most loyal and most courageous soldier of Georgia... He sacrificed himself for the love of the homeland, together with his Sworn Men [followers]... When the Sworn Men were taken to their execution, they were singing and held their heads up. They were not fanatics nor madmen, they just loved their homeland and understood what it means to sacrifice yourself for your country.

Cholokashvili and his Sworn Men figure as the symbols of the nation. They are also set as an example for contemporary Georgian men. This version of masculinity implies patriotism, courage, and self-sacrifice. It is stressed that men who express their love for the homeland in such a way are not madmen; on the contrary, they are heroes and they are something that Georgians should be proud of.

Masculinity as a marker of cultural borders, as presented in the quotes above, distinguishes Georgians from other nations and also helps them to resist empires and enemies that threaten its national independence. In these particular discourses, the Soviet Union is the enemy.

The second type of masculinity is militaristic masculinity. This version of masculinity was activated by president Saakashvili. This discourse was active during years 2004-2008. After his inauguration ceremony in 2004, Saakashvili stated that the Georgian army would be one of his priorities along with anti-corruption policies. This was the beginning of national militarization. Since Georgia has two secessionist regions (backed by Russia), a stronger army was associated with territorial integrity. In 2004, Saakashvili said that he did not want war, but that a strong army would back his diplomacy. However, Saakashvili's discourse was getting more and more antagonistic and threatening towards Russia. In conjunction with anti-Russian rhetoric, Saakashvili strengthened Georgia's relations with the U.S. and became involved in the "War on Terror" operations. Georgian troops were sent to Iraq and Afghanistan. These policies and discourse culminated in the war between Russia and Georgia, in August 2008. The dominating period of this discourse of militaristic masculinity was not very long, but the discourse was incredi- 
bly powerful and demanding. Saakashvili extensively talked about patriotism, the "Georgian military spirit," national heroes, and showing the whole world the militaristic capabilities of Georgia. He also demanded that every Georgian family participated in the making of a strong army.

"We will destroy mercilessly everyone who will enter Georgia with arms" Saakashvili stated in 2004 during the graduation ceremony of the National Defense Academy of Georgia (Saakashvili 2004c). This comment refers to Russia, which objected pro-Western policies in Georgia. Saakashvili tried to demonstrate force against Russia, whose influence in Georgia was quite strong.

On May 26, 2006 (Independence Day of Georgia) Saakashvili stated the following during the military parade:

\begin{abstract}
We greet the soldiers and officers who have received the government awards today, as well as one of the highest awards in the U.S., which is extremely rarely given to non-American officers and soldiers. It is the fate and tradition of Georgians, to prove ourselves not only while defending our country but also in the struggle for freedom, in the struggle for Georgia in the whole world (Saakashvili 2006).
\end{abstract}

Georgian men as soldiers and officers are not only valued in Georgia, but they also receive international recognition. According to Saakashvili, Georgian men have to be proud that they are involved in the projects and military operations of the U.S. They are the representatives of Georgia as a nation, and they can show Georgian militaristic capabilities to the whole world.

The army is supposed to be dominated by men, and militaristic activities are managed and carried out mostly by men. Thus, the nation becomes masculinized, while the army is instrumentalized against the supposed enemy and the army becomes the proof of Georgia's strength and usefulness to its major allies. In addition, militaristic masculinity becomes normative for men if they want to be valued by the state and nation.

The third type is neoliberal masculinity. Saakashvili was one of the major actors who produced this discourse; however, neoliberal masculinity is also promoted in the discourse of Kakha Bendukidze who was the minister in Saakashvili's government and the main author of the new economic policies. The Georgian Dream government has also continued this discourse and policies. Masculinity and neoliberalism are connected on macro and micro levels. On the macro level, the connection is expressed by promoting certain norms and values, such as holding an anti-corruption and anti-Soviet stance, focusing on investors, and supporting free trade. This functions as the macro level, because it manifests in parallel with the discursive form wherein the state enacts major reforms and policies. For example, as mentioned above, Saakashvili stated in 2004 that anti-corruption policies would be one of his priorities. While this was a popular decision, it was in compliance with the ideas of neoliberal development. The goal of these policies was to attract direct foreign investments to Georgia, so it is at least questionable if the Georgian population was the main beneficiary of these policies. The Soviet economic models and culture were also rejected in favor of the West and neoliberal capitalism. On the micro level, masculinity and neoliberalism are connected to produce subjectivities and characteristics of individual men, such as economic rationality, 
$\frac{\circlearrowleft}{0}$ knowledge of trade and calculation, and being profit-oriented. The macro-level policies would not be enough if men do not become willing participants of the new neoliberal culture and economy.

"Nowadays each corrupt official is a betrayer of the national interests," said Saakashvili in 2004, in his inauguration speech, when he declared that his government would fight against the large-scale corruption established in the country during president Shevardnadze's rule (Saakashvili 2004a). It is stated explicitly that the government views corruption as "anti-national." Later in 2004, Saakashvili said:

We have to do everything to stimulate the economy, to create new jobs, to attract investments. I've had talks about this in Davos where I met all the rich people in the world. But for this it is necessary to have a very strict order in Georgia and everyone should know their place before the law (Saakashvili 2004b).

"Strict order" and equality before the law are needed in order to attract investments. Attracting investments require other measures as well, such as deregulation. This remains invisible in Saakashvili's anti-corruption discourse; however, it was part of the state's policies. Nonetheless, the discourse establishes "attracting investments" as the only possible way of economic development and the only possible way out of poverty. There is no alternative to Georgia's neoliberal development.

Kakha Bendukidze is a harsh critic of the Soviet Union. He views the Soviet values as obstacles for the new way of life and economy. In 2010 he wrote in a blogpost:

Apart from the Soviet Union and its former parts, there is no such thing as "intelligentsia." The term "creative intelligentsia" is a Soviet term. And the phrase, "the hospital collective has done everything possible" cannot be translated into English... It takes a lot of time and effort to eradicate all these things. The important thing is to get them out of our souls (Bendukidze 2010a). ${ }^{5}$

Things that were part of the Soviet state and culture and are supposedly incomprehensible for the Westerners are the signs of the backward culture and should be eradicated. It should be replaced by the Western culture which is superior. This transformation is called upon by these leaders to happen on the micro, subjective level.

Bendukidze is also worried that Georgian men do not have knowledge of trade and/or do not know how to calculate things. The new economy requires subjects who are economically rational and who have skills of cost-benefit analysis. Thus, Bendukidze writes in another of his posts:

I'm told that in Georgia it's shameful for men to use a calculator. Weapons are good, cigarettes are ok, but a calculator is shameful. Shallowness is acceptable, while depth is not... Guys! Let's take a calculator, it's useful, we can count something (Bendukidze 2010b).

\footnotetext{
${ }^{5}$ The term "hospital collective" implies employees of a hospital, mainly surgeons, doctors, medical assistants and nurses who are responsible for "saving" the patient. In the Soviet Union, employees of any organization were referred as worker collectives. Probably this is what Bendukidze thought was untranslatable into English.
} 
As Bendukidze talks about "men," it becomes obvious once again that the nation is identified with men. In this discourse women are invisible. The masculinized nation is in need of the transformation and it should be achieved by transforming individual men. In this case, men should learn how to be neoliberal subjects. They should learn how to make economically rational choices.

Investments and free trade are considered important for Georgia's development by the government of Georgian Dream, as well. President Margvelashvili stated during his 2015 Annual Report speech in the parliament:

Our main objective is to ensure economic growth, employment, and, finally, the reduction of inequality in the country and the prosperity of each member of society... What potential do we have in this regard? The Free Trade Agreement with Europe: this is the opportunity and the new stimulus for economic growth, investments, employment, and export (Margvelashvili 2015).

Margvelashvili also mentions low levels of corruption and criminal activity in Georgia, which should be attractive for investors. Free market still figures as a norm and the neoliberal development model remains the sole form of development visible in this discourse.

The first type of hegemonic masculinity - masculinity as a symbol of the nation and/or marker of cultural borders - is quite marginal because its main producer is Zviad Gamsakhurdia (who was the president of Georgia for a relatively short period). Mikheil Saakashvili is also one of the producers of this discourse, but in his case the focus is about patriotism and national heroes and it overlaps with militaristic masculinity. The discourse of militaristic masculinity generated by Saakashvili lasted for several years and was powerful and demanding. However, the most dominant type of hegemonic masculinity is neoliberal masculinity. Its primacy is confirmed both by the period of its domination - it involves periods of Saakashvili's government and the Georgian Dream government - and by the number and political positions of actors involved in its making.

\section{The Domination of Pro-Western Nationalism}

In Soviet Georgia, the goal of Georgian nationalism was to become an independent state. However, after obtaining independence, Georgians have to deal with a geopolitical choice between Russia and the West. The elite nationalism is also produced along these lines. All leaders studied by me - except Ivanishvili - are explicitly anti-Russian and anti-Soviet. President Gamsakhurdia was anti-Western as well, but all other leaders are pro-Western. Thus, we can speak about the domination of pro-Western nationalism.

Gamsakhurdia claimed that both the Soviet Union and the West were empires, and he sought to "decolonize" Georgia. Shevardnadze, who replaced him, sought "to build democracy" which meant to open and prepare Georgia for the Western-style governance: liberal democracy. His rule lacked legitimacy in Georgia but he managed to create an order and system which was ac- 
ceptable to both Russia and the West ${ }^{6}$. Accordingly, he maintained his power despite the lack of legitimacy and large-scale corruption and took measures for creating certain "democratic" institutions. Saakashvili and his government were the first ones who proactively claimed a European identity for Georgia. "We are not just old Europeans, we are the oldest Europeans, and, therefore, Georgia holds a special position in European Civilization," stated Saakashvili during his inauguration speech in 2004 (Saakashvili 2004a). Saakashvili's discourse was aggressively anti-Russian; he used militarization to threaten Russia, which was figured as an enemy. Bendukidze was anti-Russian as well. His discourse was characterized by the radical negation of the Soviet political economy and cultural values. In these discourses of the Rose Revolution government, the Soviet Union/Russia and the West became too polarized. The negation of the Soviet Union/Russia was paralleled with policies of militarization, anti-corruption, neoliberal reforms, claiming European identity, and an alliance with the U.S. The Georgian Dream government somewhat changed this legacy, mostly by becoming less aggressive towards Russia. However, European identity has become sustainable. According to president Margvelashvili, the post-Soviet country (Georgia) has to become a European state. In the 2015 Annual Report, he said: "Historically and culturally, we [Georgians, the Georgian state] have been Europe - not just a part of it, but for centuries an active participant of European development and creations."

Georgia's political orientation towards the West is evident. However, there can be different interpretations concerning the domination period and quality of pro-Western elite nationalism. On the one hand, it can be said that pro-Western nationalism dominates in Georgia since the ousting of president Gamsakhurdia. All of the later leaders were oriented towards the model of the Western state (liberal democracy) and cooperated with the Western powers. However, the configuration of state institutions, economy, and foreign policy was changing: during Shevardnadze's rule it was a weak and fragile state, crony capitalism and a foreign policy based on political maneuvering; under Saakashvili's governance it was strong state institutions, militarism, neoliberal capitalism, European identity, and an alliance with the US; under the Georgian Dream government there are again strong state institutions, neoliberal capitalism, and European identity, which has now been complemented with the Association Agreement between Georgia and the European Union.

\footnotetext{
${ }^{6}$ Shevardnadze's lack of legitimacy was connected with the violent ousting of president Gamsakhurdia, as many people, especially, in west Georgia continued to support him. Civil war over this issue continued in 1992 and 1993. In addition, war in Abkhazia (also known as the Georgian-Abkhaz conflict) broke out in 1992, ending in 1993 by Abkhazia's secession. As a result, the Georgian state lost control over the region. At one point - he spoke about it in the parliament, in March, 1994 - Shevardnadze even appealed military intervention from Russia, because he could not control the situation in west Georgia, Abkhazia, and Samegrelo, where the support of Gamsakhurdia was especially strong. In this context, he also agreed for Georgia to join the Commonwealth of Independent States (CIS). These events show that Shevardnadze, especially in the beginning of his rule, used external forces to make and keep his power. His rule lacked internal consent, as strong hegemonic projects were yet to be created.
} 
Though, there still can be a second interpretation. The so-called Rose Revolution in 2003 was the point where Georgia proclaimed clearly its geopolitical choice in favor of the West. Saakashvili, as one of the leaders of the revolution and later the leader of this "new Georgia," made sure to discursively connect Georgia with Europe and the European Union. The new government also introduced discourses and policies dealing with corruption, neoliberal economy, culture, individual subjectivities, openly and aggressively anti-Soviet and anti-Russian attitudes, and militaristic actions and wars. All these were done in the name of pro-Western choice, under the pretense of including Georgia in the developed and progressive world. The idea of progress was constructed as being "like the West" and doing "what the West wants." In reality, the geopolitical choice of Georgia, and the domination of pro-Western nationalism following it, made Georgia open for the darkest aspects and effects of Western civilization, such as adopting a neoliberal system and being complicit in the US military interventions and domination of developing countries. Thus, the dominant types of hegemonic masculinities - militaristic masculinity and neoliberal masculinity - were also generated and shaped during this period. This means that elite pro-Western nationalism in Georgia has so far been connected with this kind of patriarchy and hegemonic masculinities.

\section{Conclusion}

The analysis of discourses of Georgian political and economic elites reveals the types of masculinities and nationalisms that have become hegemonic in post-Soviet Georgia. There are important and transformative points in the political history of post-Soviet Georgia, such as gaining independence, accepting the new state model of liberal democracy, making the geopolitical choice between Russia and the West, introducing neoliberal capitalism, and acquiring European identity. Overall, Georgian elite nationalism is mostly pro-Western nationalism. We can see orientation towards the West in different periods of Georgia's history represented in different configurations of state institutions, economy, and foreign policy. As an alternative interpretation, we can also see the Rose Revolution as the major starting point for pro-Western nationalism - the pro-Western choice of Georgia has become qualitatively different and is expressed in various reforms and policies. In parallel, this analysis reveals three types of hegemonic masculinity. The first type - masculinity as a symbol of the nation and/or marker of cultural borders - focuses on Georgia's independence and cultural autonomy. In some cases, this form of masculinity does not go well with, and even rejects, pro-Western nationalism. However, there are also two other types of hegemonic masculinity: militaristic masculinity and neoliberal masculinity. They are much more powerful than the first type, which is evident by both qualitative and quantitative indicators. These types were activated after the Rose Revolution, by president Saakashvili's government. The domination of the militaristic type was quite short lived. However, the neoliberal type has become the stable form of hegemonic masculinity. These types - and especially, neoliberal masculinity - go hand in hand with hegemonic pro-Western nationalism. In the discourses of these 
elites, ideas of these masculinities and pro-Western nationalism support and construct each other.

Anderson, Benedict. 2016. Imagined Communities: Reflections on the Origin and Spread of Nationalism. London: Verso.

Balibar, Etienne. 2010. "The Nation Form: History and Ideology." Race, Nation, Class: Ambiguous Identities, by E. Balibar and I. Wallerstein, 86-106. London: Verso.

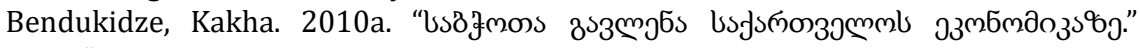
["The Soviet Influence on Georgia's Economy."]http://www.tabula.ge/ge/ blog/52306-sabchota-gavlena-saqartvelos-ekonomikaze

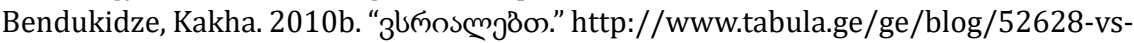
rialebt

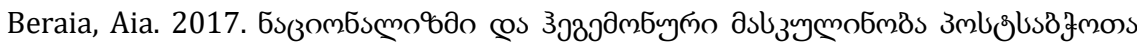

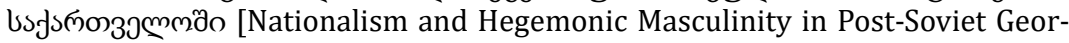
gia]. Tbilisi: Women's Fund in Georgia.

Connell, R. W. 1991. "Hegemonic Masculinity and Emphasized Femininity." Gender and Power: Society, the Person, and Sexual Politics, 183-188. Cambridge: Polity Press.

Connell, R. W. 2005. Masculinities. Berkeley: University of California Press.

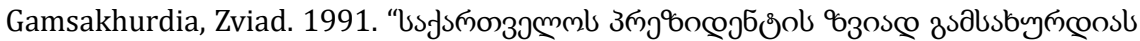

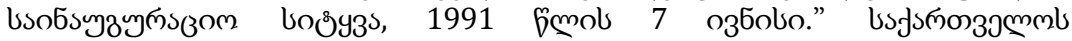

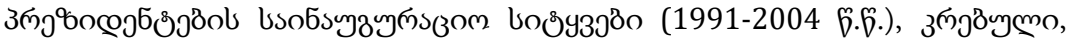

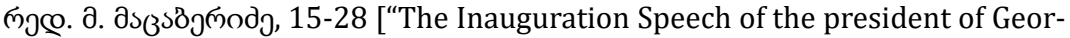
gia, Zviad Gamsakhurdia, 7 June, 1991." The Inauguration Speeches of the Presidents of Georgia (1991-2004), Collection, ed. by M. Matsaberidze, 15-28]. Tbilisi: Institute of Political Sciences.

Gramsci, Antonio. 1992. Selections from the Prison Notebooks of Antonio Gramsci, trans. and ed. by Q. Hoare \& G. Nowell Smith. New York: International Publishers.

Jones, Stephen F. 2006. “Georgia: Nationalism from under the Rubble." After Independence: Making and Protecting the Nation in Postcolonial and Postcommunist States, ed. by L. W. Barrington, 248-276. Ann Arbor: The University of Michigan Press.

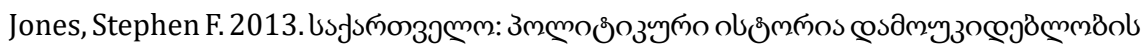

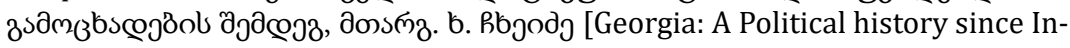
dependence, trans. by K. Chkheidze]. Tbilisi: Center for Social Sciences.

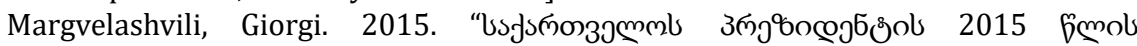

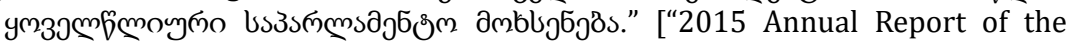
President of Georgia."] https://www.president.gov.ge/ka-GE/prezidenti/cliuri-mokhseneba/2015-clis-saparlamento-mokhseneba.aspx

Nagel, Joane. 1998. "Masculinity and Nationalism: Gender and Sexuality in the Making of Nations." Ethnic and Racial Studies, 21 (2): 242-269.

Netgazeti. 2016. "What has (not) Changed in the Sphere of Women's Political Partic-

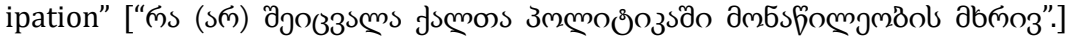
http://netgazeti.ge/news/160154/

Reeser, Todd W. 2010. "Masculinity and the Nation." Masculinities in Theory: An Introduction, 171-199. Malden: Wiley-Blackwell.

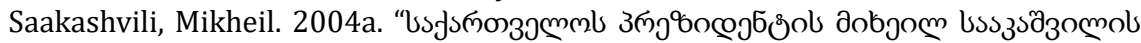

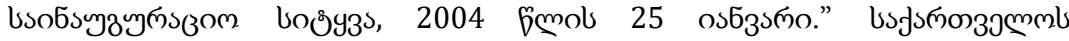

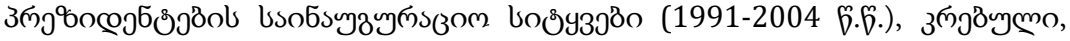

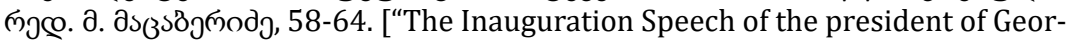
gia, Mikheil Saakashvili, 25 January 2004." The Inauguration Speeches of the 
Presidents of Georgia (1991-2004), Collection, ed. by M. Matsaberidze, 58-64.] Tbilisi: Institute of Political Sciences.

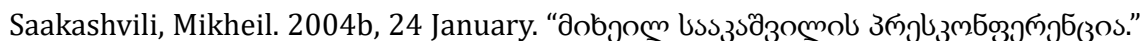

["The Press Conference of Mikheil Saakashvili."] DVC E4-168. The Archive of Georgian Public Broadcaster, Tbilisi.

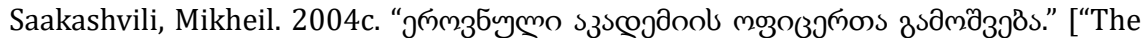
Graduation Ceremony of the National Academy."] DVD A10-598. The Archive of Georgian Public Broadcaster, Tbilisi.

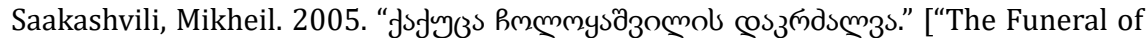
Kakutsa Cholokashvili."] DVC C4-198.The Archive of Georgian Public Broadcaster, Tbilisi.

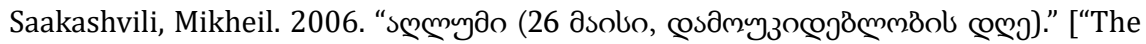
Parade (26 May, the Independence Day)."] DVC F8-02. The Archive of Georgian Public Broadcaster, Tbilisi. 


\section{Чей феминизм? Феминистские движения в России и «западная» культурная гегемония}

$\mathrm{C}$ того самого момента, как я пришел в свою первую феминистскую активистскую группу, в разговорах о феминизме со знакомыми и совершенно незнакомыми людьми мне, как и моим подругам, постоянно приходилось объяснять одно и то же: нет, феминизм - это не что-то оторванное от жизни. Дело не в том, что мы начитались «западных» ${ }^{1}$ феминисток. Это не наносная идеология, и это не надуманные проблемы. Мы не высасываем их из пальца, мы говорим о том, что происходит с нами, здесь и сейчас. Феминизм - это то, что касается каждой женщины*2, говорили мы. А нас все время подозревали и обвиняли в том, что мы пытаемся насаждать что-то чуждое.

Обвинения в навязывании «западных ценностей» или «чуждой идеологии» постоянно сопутствуют феминизму в России и особенно обострились в последние годы, с оживлением дискурсов «холодной войны». Часто оппонент_ки ${ }^{3}$ полностью отказывают российским феминист_кам в политической самостоятельности. Более того, и в самих феминистских сообществах встречаются то в скрытой, то в явной форме идеи о вторичности российского феминизма по отношению к «западному».

\footnotetext{
${ }^{1}$ Кавычки вокруг слов «западные» и «Запад» я ставлю с двойной целью: во-первых, подчеркнуть, что речь идет о воображаемой области/общности, которая на самом деле не имеет четких границ, а во-вторых, обозначить критическую дистанцию по отношению к этому понятию и тянущемуся за ним шлейфу политических коннотаций.

2 Звездочку к слову «женщина*» я добавляю для того, чтобы подчеркнуть, что речь идет обо всех людях с опытом гендерного угнетения, а не только о приписанном при рождении поле и даже не об идентичности. Такое написание я заимствую у немецких и австрийских квир_феминист_ок. Правда, в то время, о котором я говорю, никто из нас звездочкой не пользовал_ась. Я тогда определял себя как женщину, и мой феминизм не был транс*инклюзивным.

${ }^{3}$ Я использую нижнее подчеркивание, когда имею в виду людей всех гендеров, включая небинарные. При обсуждении высказываний других людей я иногда не ставлю нижнее подчеркивание, чтобы не приписывать им того понимания гендерной системы, которого они, возможно, не разделяют.
} 
Может ли феминизм быть российским или он всегда происходит с «Запада»? Могут ли люди в Восточной Европе, на постсоветском пространстве, в России производить феминистское знание и методы или они всегда только повторяют, заимствуют, догоняют и наверстывают? Обречены ли они всегда учиться у «Запада»? Для меня эти вопросы приобрели особое значение с тех пор, как я живу в Германии и мне нужно как-то осмыслять свое мигрантское положение. Но я уверен, что размышлять и говорить об этом имеет смысл не только для мигрант_ок: в глобальном культурном пространстве, когда значительная часть обмена знаниями и идеологиями и их распространения происходит онлайн, все мы включены в том числе в глобальные отношения власти. И в этом контексте вопрос «чей феминизм?» - это еще и вопрос того, чтобы ценить по достоинству свой активизм и свой интеллектуальный вклад.

В своих размышлениях об этом я опираюсь на интервью, которые брал у российских феминист_ок для своего исследования, посвященного современным феминистским движениям в России. Интервью проводились в 2015-2016 годах, и хотя далеко не все они затрагивали тему отношений с «Западом», некоторые участницы поделились со мной своими развернутыми позициями; отрывки из их интервью я и рассматриваю ниже.

Что же заставляет нас обращаться к «западным» источникам за языком и способами осмысления наших собственных жизней? Почему мы предполагаем, что именно там находится источник верного, подлинного знания? Ответ, похоже, кроется в явлении, которое называют культурной гегемонией «Запада». Гегемония - это власть, которая не опирается на прямое насилие. Отношения между «Западом» и Россией не колониальные - именно потому, что колониальное насилие в них отсутствует. Тем не менее, всем нам хорошо знакомо жесткое противопоставление России или, шире, Восточной Европы и «Запада»как двух противоположных полюсов, когда «западный» конструируется как полюс прогресса, просвещения и свободы, а «восточный» - наоборот, как полюс отсталости, невежества и закрепощенности (Mizielińska and Kulpa 2011; Wiedlack and Neufeld 2014). Этот механизм реализации «западной» культурной гегемонии иногда называют дискурсом отставания (Koobak and Marling 2014). Он представляет специфическую для «Запада» историческую траекторию эталона «нормального развития», а все другие якобы «отклоняются» или «отстают» от этой нормы. По сути, дискурс отставания использует само время как инструмент культурной гегемонии (Kulpa, Mizielińska, and Stasińska 2012).

Феминизм в дискурсе отставания, безусловно, принадлежит к «западным ценностям». Это одна из тех точек, в которой, как предполагается, Россия должна нагнать «Запад», хотя не во всех версиях дискурса отставания это признается возможным. Татьяна Болотина, российская феминистка и активистка, говорит об этом так:

\footnotetext{
${ }^{4}$ Все упоминаемые имена участни_ц согласованы с ними. Я привожу цитаты с сохранением пауз и колебаний, потому что все эти детали помогают увидеть, как мои собеседни_цы размышляют непосредственно в ходе разговора.
} 
То есть У... россиянок в массе своей есть такое ощущение второсортности по сравнению со странами первого мира, особенно США, и это проявляется у всех по-разному: ну, там, многие в махровый национализм ударяются. Среди феминисток это в основном не так, то есть в основном такое ощущение, что здесь, у нас, отстой такой, что у нас, типа, плохой менталитет, что никогда ничего не будет лучше... Что там, где-то там да, все здорово, а у нас здесь все плохо, потому что мы такие плохие... Вот, и на мой взгляд, это очень похоже на ощущение женщин в целом по отношению к мужчинам: что, типа, мужчины такие великие, они все изобрели, написали и так далее, а мы, типа, способны только рожать и ... быть сексуальными объектами.

Чтобы сделать гегемонию «Запада» явной и очевидной, Татьяна использует прием, который очень популярен в феминистских и других активистских сообществах: сравнить менее изученный или менее понятный вид отношений власти с другим, уже хорошо известным и описанным. Здесь Татьяна сравнивает то, как женщины в целом интернализируют, или усваивают сексизм и мизогинию, с тем, как россиянки интернализируют ощущение собственной «второсортности» по отношению к «Западу». Получается, что в обоих случаях те, кто обладает властью, конструируются как достойные, а те, кто находится в подчиненном положении, - как недостойные, причем их подчиненное положение увязывается с якобы внутренне присущими им недостатками.

Реагировать на «западную» гегемонию и «дискурс отставания» можно по-разному, и если интернализировать «западный взгляд» - это один путь, то противоположный ему, очевидно, - отвергать «западный взгляд», противопоставляя ему национализм. Но так ли это на самом деле? Татьяна в приведенной цитате занимает критическую дистанцию по отношению к обоим вариантам, и благодаря этому становится очевидным, что выбор ими не исчерпывается. Господствующие дискурсы обычно приравнивают критику «Запада» к национализму, а несогласие с политикой собственного (например, российского) государства - к некритичному принятию политики «западной». Но Татьяна выше показывает, что «национализм или самопринижение» - это ложный выбор.

Тем не менее, поскольку феминизм представляется - и в дружественных, и во враждебных дискурсах - «западным» изобретением и элементом из набора «западных ценностей», в российских феминистских сообществах в самом деле больше распространена тенденция в той или иной степени обесценивать свои идеи, свою работу и достижения по сравнению с «западными образцами». Часто, например, история и развитие феминизмов в России проецируется на мейнстримный «западный» способ рассказывать историю феминизма через модель «трех волн» ${ }^{5}$; это порождает дискуссии о том, «пора ли» России присоеди-

\footnotetext{
${ }^{5}$ Между тем, модель «трех волн» - не единственный и едва ли лучший способ представлять себе историю феминизмов вообще и «западных» феминизмов в частности. Ее критикуют за то, что она стирает различия в истории и повестке феминистских движений в разных странах (Dean and Aune 2015), игнорирует все формы феминистского действия, кроме моментов самого массового протеста (Staggenborg and Taylor $2005)$ и исключает из рассмотрения деятельность бедных женщин, женщин рабочего класса и женщин цвета по всему миру (Naples 2015).
} 
няться к «третьей волне» или нужно сначала основательно «нагнать» «вторую». Намеренно или неосознанно такие дискуссии задействуют как предпосылку идею о том, что российским феминист_кам в любом случае нужно учиться у «западных».

Именно об «учебе», точнее, о передаче знаний, мне бы хотелось поговорить дальше. Кажется, что поиск интеллектуальных и идеологических оснований имеет сейчас очень большое значение для низовых феминистских движений в России. Я думаю, что на это есть несколько причин. Во-первых, феминистским движениям постоянно приходится доказывать, что они имеют право на существование в условиях, когда все (и государство, и общество, и разнообразные облеченные властью институты, в частности, академия) им в этом отказывают. Во-вторых, феминистские сообщества в России, как и в других местах, переживают множество идеологических конфликтов и расколов, и в этих обстоятельствах им необходим фундамент, ядро базовых знаний и идей, с которыми были бы согласны привержен_ки всех идеологических направлений. Такое ядро самых авторитетных и основополагающих, иначе говоря, мейнстримных для феминизма концепций даже имеет специальное название, хорошо знакомое всем, кто общается в феминистских (особенно онлайн) тусовках, - «матчасть». Поскольку матчасть должна отвечать потребности движений в истории и авторитетности, неудивительно, пожалуй, что львиную долю ее составляют «западные» тексты «второй волны». Эти тексты переводятся зачастую силами активист_ок и снова и снова распространяются по феминистским онлайн-площадкам.

Проблема, однако же, в том, что эти тексты, из которых вроде бы должна выводиться актуальная для современных российских условий политическая практика, - это «западная» феминистская теория. А она, хотя и претендует на универсальность, далеко не всегда хорошо объясняет постсоциалистические реалии. Вот как об этом говорит Татьяна Болотина:

А те паблики ${ }^{6}$, где есть всякая матчасть и где цитируют, ну... современных феминисток как матчасть, меня не интересуют. [...] В том плане, что... интересны проблемы, с которыми люди сталкиваются здесь и сейчас. То есть не то, что было там когда-то описано в Америке или где-то еще. И... Ну, я считаю, что все-таки то, что происходит в современной России, оно немножко отличается от... другой страны и другого времени.

На мою просьбу привести пример, Татьяна поясняет:

Ну, самый элементарный пример, допустим... американской матчасти неподходящей - это домохозяйка среднего класса, то есть там очень много на эту тему. У нас здесь, во-первых, мало домохозяек и... ну, среднего класса так... не знаю [смеется] в общем, среднего класса тоже гораздо меньше, скажем так․ Вот, и... У нас история не такая, то есть

\footnotetext{
${ }^{6}$ Речь идет о пабликах (то есть публичных страницах) Вконтакте.

${ }^{7}$ Колебания Татьяны по поводу понятия «средний класс» заинтересовали меня, тем более что у меня оно тоже вызывало смутные сомнения. Академические источники говорят, что определить, что такое «средний класс» в России, непросто (Remington 2011; Gontmakher and Ross 2015). Возможно, еще один пример «западной» концепции, плохо применимой к постсоветскому обществу.
} 
в то время, когда в Америке в среднем классе женщины в основном сидели дома, занимались домашним хозяйством, у нас женщины в основном работали, у них были две-три смены.

Татьяна подчеркивает различия между реалиями современной России и США середины XX века и опирается на эти различия, чтобы объяснить свою критику русскоязычных феминистских платформ, публикующих «матчасть». Пример, который она приводит, действительно хрестоматийный во всех смыслах слова: именно концепция домохозяйки среднего класса вызывала раздражение уже у предыдущих поколений феминисток из постсоциалистических стран. Например, болгарская феминистка Корнелия Славова в тексте 2006 года суммировала свой опыт обсуждения со студент_ками «Загадки женственности» Бетти Фридан: студент_ки оценивали проблемы домохозяйки среднего класса как «устаревшие и не имеющие к ним отношения» ${ }^{8}$. Славова пишет:

$\mathrm{У}$ нас, восточноевропейских женщин, было другое ощущение женской идентичности, относительно независимой от фигуры мужа, но тесно связанной с коммунистическим государством. Мы еще не испытали на себе западный «культ домовитости», «мифы о красоте» и консьюмеризм. Зато мы интернализировали социалистический миф «суперженщины» - сочетающей домашние и общественные обязательства, зачастую ценой жертв, самоуничижения и самоотрицания (Slavova 2006).

Спустя двенадцать лет и «мифы о красоте», и консьюмеризм успели стать проблемами для женщин* в постсоциалистических странах - и, соответственно, вошли в повестку постсоциалистических феминистских движений. Но и тезис Славовой о суперженщине актуальности не потерял. «Загадку женственности» и ее феминистскую аргументацию, ставящую в центр рассмотрения домохозяйку среднего класса, принято считать одним из краеугольных камней «матчасти». Но это узкоспецифическая «матчасть», которая не подходит как фундамент для политической практики феминист_кам в постсоциалистических странах и не может претендовать на статус универсального стандарта феминизма. На это и указывает Татьяна, тем самым отвергая и «ученическую» позицию по отношению к «западному» феминистскому знанию.

Есть и другие конструктивные способы взаимодействовать с «западным» знанием, сохраняя при этом критичность по отношению к гегемонии «Запада». Вот что говорит другая моя собеседница, Катерина:

...Еще, кстати, почему [я] не очень люблю всякие эти группы и паблики - они возьмут какой-нибудь текст семидесятых, который написан с употреблением лексики, которую, блин, даже я не всегда понимаю [...] Ну... зачем? Для кого ты это пишешь? Ты напиши про себя, про свой опыт! [...] Популяризация - это объяснение простым языком этих всех вещей, то есть... Мне кажется, вот Бетти Фридан сделала вообще классную вещь. Это же, блин, даже... ничего делать не надо, ты бери [и] просто то же самое на русском напиши! То есть она просто взяла опыт женщин и на их примере... показала, насколько было ущербно

\footnotetext{
${ }^{8}$ Здесь и ниже перевод цитат мой.
} 
это... время и насколько себя женщины почувствовали свободнее, когда они смогли высвободиться из этого. Да ты сделай то же самое на русском языке, тебе кто мешает? Светлана Алексиевич, кстати, в этом плане очень классную вещь сделала. Она вот популяризует эту антивоенную риторику, да? Она собирает эти все интервью, это гигантская работа, это вообще... Людмила Петрановская - она популяризует психологию, она очень грамотно все это расписывает. Мне вот нравится. Там, не знаю... кто? Ну, то есть вот в таком ключе это надо брать и просто популяризировать.

Популяризация - важная тема, к которой Катерина много раз возвращается в ходе нашего разговора: она считает популяризацию одной из центральных задач для феминистских движений в России. Как и Татьяна, Катерина начинает с критики феминистских онлайн-платформ за репосты «текстов семидесятых» - текстов «западных» авторок «второй волны». Но обосновывает она свою критику несколько иначе: для нее главный аргумент «против» - это недоступный язык, который делает эти тексты сложными для восприятия. А это мешает популяризации вместо того, чтобы способствовать ей. В то же время Катерина призывает писать исходя из собственного опыта - из этого можно сделать вывод, что она тоже видит различия в социальных реальностях «западных» семидесятых и современной России. В свете этого может показаться странным, что дальше она приводит «западную» авторку «второй волны», Бетти Фридан (похоже, это все же неизбежная фигура и ориентир в таких дискуссиях), как пример успешной популяризации. Но, на мой взгляд, противоречия здесь на самом деле нет. В первую очередь Катерина ценит в Бетти Фридан ее подход - «объяснение простым языком этих всех вещей», а не ее анализ «этих вещей», то есть положения женщин в послевоенных США.

Еще одно основание для такой трактовки слов Катерины появляется ниже, когда она продолжает свой ряд достойных подражания популяризаторок и приводит русскоязычные примеры: беларусскую писательницу и нобелевскую лауреатку Светлану Алексиевич и российскую психологиню Людмилу Петрановскую (обе - уважаемые публичные интеллектуалки, которые при этом не называют себя феминистками). Катерина ставит Алексиевич и Петрановскую в один ряд с Фридан - и тем самым показывает, что она совсем не заинтересована в том, чтобы универсализировать «западные» теории. Катерину интересуют, прежде всего, действенные методы популяризации, поскольку она твердо убеждена в необходимости распространять феминистские идеи. Кроме того, она, очевидно, привержена политической стратегии «выбери женщину»: противостоять андроцентризму, отдавая предпочтение женщинам, женским голосам и достижениям. Выстраивая ряд «Фридан Алексиевич - Петрановская», Катерина показывает, что ей интересно учиться у разных женщин, вне зависимости от их страны, языка или сферы деятельности. Катерина высказывается против догматичного воспроизведения «западных» теорий и их некритичного применения к современному российскому контексту. Она призывает учиться активно 
и избирательно, признавать и ценить разнообразные источники и заимствовать у каждого из них то, что тебе нужно и подходит, - и в то же время брать за точку отсчета собственный опыт.

Такой подход, очевидно, несовместим с тем самопринижением или самообесцениванием, которое рождается из усвоения «дискурса отставания». Татьяна, в свою очередь, тоже считает лучшим источником знаний локальный опыт и истории: она говорит, что предпочитает читать вместо «матчасти» личные истории, которыми делятся «обычные» женщины в постах и комментариях. Вот как она их использует:

Татьяна: Да, поэтому очень интересно, собственно, что сейчас происходит, и... Я на основе этого составляю какую-то собственную, там, [смеется] теорию, что называется...

Ваня: А теорию это как?

Татьяна: Э-э-э, ну... представление о том, что сейчас актуально и как это решать.

Откровенно говоря, меня глубоко впечатляет та смелость, с которой Татьяна возвращает себе слово «теория», «забирая» его у господствующих «западных» и академических дискурсов. Она делает это, с одной стороны, используя его почти без смущения для обозначения своего собственного анализа, а с другой - определяя теорию как фундамент для политического действия, как инструмент и подспорье для активизма, а не что-то стоящее выше его. В конечном счете получается, что Татьяна последовательно противостоит и академической, и «западной» гегемонии. Возвращая себе слово «теория», она отказывается преуменьшать свою интеллектуальную работу, вопреки негласным предписаниям дискурса отставания. А основывая свою теорию на опыте и историях «обычных» женщин, она придает больший вес этим историям - и тем самым, опять же, действует против предписываемого гегемонными дискурсами обесценивания локального знания.

И Татьяна, и Катерина возражают против того, чтобы заимствовать «западное» знание без разбора. Обе критикуют универсализацию «западной» теории и тем самым сопротивляются «западной» культурной гегемонии. Различаются их подходы тем, что именно они предлагают взамен некритичному воспроизведению «западного» знания. Катерина не отвергает «западные» источники знания, но дополняет их русскоязычными и постсоветскими. На протяжении своего интервью она представляет целую галерею известных женщин, которые ее вдохновляют - и «западных», и не «западных»9. Татьяна, верная своей критике

\footnotetext{
${ }_{9}^{9}$ В свою очередь, Корнелия Славова в процитированной выше статье (Slavova 2006) обращает внимание на то, как много общего или похожего у восточноевропейских феминисток с черными и постколониальными феминистками: это касается и восприятия гендера в контексте пересекающихся угнетений, и переживания «западной» гегемонии. Славова опирается на теории постколониальных и черных феминисток и тем самым показывает возможности для транснациональных союзов помимо или в обход мейнстримного «западного» феминизма привилегированных женщин.
} 
«западной» гегемонии, полностью отвергает идею ориентироваться на «западные» образцы. Более того, она вообще отвергает мысль брать пример с кого бы то ни было, выказывая редкую последовательность в своем сопротивлении любым иерархиям. Вместо этого она настаивает на том, чтобы ценить, поддерживать и продвигать местное, локальное знание, которое производят неизвестные, «обычные» женщины.

Хотя господствующие дискурсы - российские и «западные», академические и медийные - создают впечатление, будто российский феминизм (в тех случаях, когда они вообще признают его существование) полностью вторичен по отношению к «западному», знакомство с реальной практикой и позициями российских феминист_ок убеждает, что это совсем не так. Высказывания Татьяны и Катерины, приведенные выше, показывают, насколько глубоко феминистская деятельность может быть укоренена в локальном российском контексте, и дают вдохновляющие примеры критического взаимодействия в «западным» знанием. Даже если «западная» гегемония не принадлежит к числу самых острых проблем на повестке российских феминистских движений сегодня, я все же надеюсь, что такие высказывания, ставящие в центр внимания локальную историю, знания и опыт, будут звучать чаще. Потому что именно освобождение от «западной» гегемонии и оценка по достоинству собственных достижений может быть залогом транснациональной солидарности, основанной на равном диалоге и взаимном уважении.

\section{Лumepamypa ${ }^{10}$ :}

Dean, Jonathan, and Kristin Aune. 2015. "Feminism Resurgent? Mapping Contemporary Feminist Activisms in Europe." Social Movement Studies 14 (4): 375-95.

Gontmakher, Evgeny, and Cameron Ross. 2015. "The Middle Class and Democratisation in Russia." Europe-Asia Studies 67 (2): 269-84.

Koobak, Redi, and Raili Marling. 2014. "The Decolonial Challenge: Framing Post-Socialist Central and Eastern Europe within Transnational Feminist Studies." European Journal of Women's Studies 21 (4): 330-43.

Kulpa, Robert, Joanna Mizielińska, and Agata Stasińska. 2012. “(Un)translatable Queer?, or What Is Lost and Can Be Found in Translation..." Import - Export Transport. Queer Theory, Queer Critique and Activism in Motion, edited by Sushila Mesquita, Maria Katharina Wiedlack, and Katrin Lasthofer, 115-45. Vienna: Zaglossus.

Mizielińska, Joanna, and Robert Kulpa. 2011. “Contemporary Peripheries: Queer Studies, Circulation of Knowledge and East/West Divide." In De-Centring Western Sexualities: Central and Eastern European Perspectives, 11-26. Ashgate Publishing Limited.

\footnotetext{
10 Уже завершая работу над текстом, я заметил, что все источники, на которые я ссылаюсь, - англоязычные, хотя большинство автор_ок - восточноевропейские. Бо́льшую иронию для текста, критикующего «западную» гегемонию, трудно себе представить. Не знаю, говорит ли это больше о том, как функционирует глобальная академия, или о проблемах в моей личной практике; так или иначе, передо мной, очевидно, остается еще большое поле для рефлексии.
} 
Naples, Nancy. 2015. "Confronting the Future, Learning from the Past: Feminist Praxis in the Twenty-First Century." In Different Wavelengths: Studies of the Contemporary Women's Movement, edited by Jo Reger, 215-36. Routledge.

Remington, Thomas F. 2011. "The Russian Middle Class as Policy Objective." Post-Soviet Affairs 27 (2): 97-120.

Slavova, Kornelia. 2006. "Looking at Western Feminisms Through the Double Lens of Eastern Europe and the Third World." In Women and Citizenship in Central and Eastern Europe, edited by Jasmina Lukić, Joanna Regulska, and Darja Zaviršek, 245-265. Aldershot: Ashgate.

Staggenborg, Suzanne, and Verta Taylor. 2005. “Whatever Happened to the Women's Movement?" Mobilization 10 (1): 37-52.

Wiedlack, Katharina, and Masha Neufeld. 2014. "Lost in Translation: Pussy Riot Solidarity Activism and the Danger of Perpetuating North/Western Hegemonies." Religion and Gender 4 (2): 145-65. 


\section{"Racism" versus "Intersectionality"? Significations of Interwoven Oppressions in Greek LGBTQ+ Discourses}

J

une 14, 2014. The crowd is gathering in Klafthmonos Square, waiting for the Athens Pride March to begin. An activist stands in the shade of a rainbow umbrella held in one hand, wearing a heart-shaped sign that denounces the denial of "the right to family" to LGBTQI+ people as the quintessence of racism. In one sense, the slogan is uncontroversially on point, as the theme of the 10th Athens Pride festival was "A Family Affair," intended to protest discrimination in the family code and the exclusion of same gender partners from civil partnerships and marriage. But what to make of the reference to "racism" to describe legal discrimination resulting in exclusion from "reproductive citizenship" (Roseneil et al. 2013) on the basis of gender and sexuality, not "race"? Simple error? Egregious appropriation? Semantic drift?

This paper seeks to make "racism" strange, by exploring its invocation in the sociolinguistic context of LGBTQI+ activism in Greece, where it is used in ways that may be jarring to anglophone readers. In my ongoing research on the conceptualisation of interwoven oppressions in Greek social movement contexts, I have been interested in understanding how the widespread use of the term "racism" as a superordinate category to reference forms of oppression not only based on "race," "ethnicity," and "citizenship" (e.g., racism, nationalism, xenophobia) but also those based on gender, gender identity, and sexuality (e.g., sexism, transphobia, and homophobia) relates to the increased adoption of "intersectionality" in movement discourses. In ordinary parlance, this commonplace usage of "racism" as an "umbrella term" nevertheless retains its etymological link to "race," while its scope is extended to other regimes of superiority/inferiority or privilege/oppression. If intersectionality presupposes that oppressions are ontologically multiple and analytically separable, the use of "racism" as an umbrella concept seems to point in the other direction, implying that all forms of oppression originate from a common source, have a similar ontological basis, or generate privilege for the same social agents, who deploy similar tactics vis-à-vis oppressed groups. My research examines how intersectionality - widely understood as a multi-axial theory of oppression, which contends that power relations are multiple, distinct, and irreducible to one another, yet converge simulta- 
neously in the experiences of multiply oppressed social groups - relates to the use of "racism" as a struggle concept in Greek, but also in other languages commonly used in Greece, such as Albanian (racizmi) and Arabic (eunsuria). In this paper, I examine how these two vocabularies - of racism and intersectionality - are operative in movement discourses, but also how they shape and are shaped by activists' perceptions, analyses, and theories of oppression.

\section{Methodology: conversation}

During the stage of fieldwork on which this paper is based (summer and autumn of 2015), I conducted eleven distinct conversations with twenty-two people who belong to ten collectives, groups, or organisations. Each conversation lasted, on average, two hours. I met with members of the following groups, organisations and collectives: The Gay and Lesbian Community of

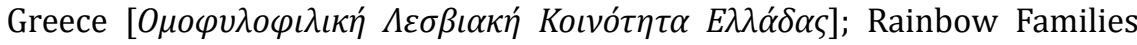

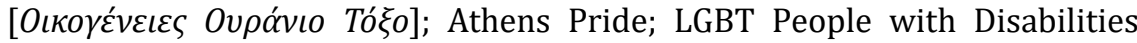
[ $\Lambda O A T A \mu \varepsilon A]$; Thessaloniki Rainbow Youth; Colour Youth; Terminal 119; Antifa Negative/Fight Back!; Queericulum Vitae; and Homophobia and Transpho-

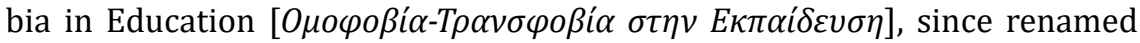

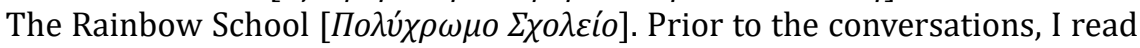
texts produced by each of these groups in published brochures, edited volumes, posters, websites, and graffiti, and also conducted a systematic survey of the database, "New Movements in Greece: Material on Gender and Sexuali-

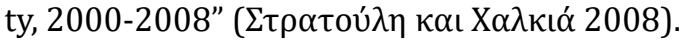

Rather than define these conversations as a source of empirical data, I approached them as sites of theoretical production, and I analyse the transcripts of our conversations as theoretical texts. Our aim was to reflect upon the struggle concepts structuring our perceptions and imaginations; our conversations were, therefore, a place of meeting or crossing between philosophy and social anthropology. In the introduction to their volume The Ground Between: Anthropologists Engage Philosophy, Veena Das, Michael Jackson, Arthur Kleinman and Bhrigupati Singh argue that the work of the anthropologist may share common points with that of the philosopher: each is concerned with understanding experience, whether by retrieving concepts animated in life worlds or by drawing them from abstract discussions and thought experiments, which one later attempts to adapt to the flow of experience (Das et al. $2014,6)$. Singh argues that, through philosophical attention to concepts, we can construct a genealogy of thought in the field of anthropological research (Singh 2014, 160). Still, he prompts us to question what, in the final analysis, constitutes a concept. How do our own concepts affect our research processes? Singh argues that concepts can reorient our affects, our perceptions, and, vice versa (Singh 2014, 161). While the anthropologist embarks on research with specific concerns, in the process she often comes to reconsider her desires, and to reflect upon how her questions are shaped by her own conscious or unconscious philosophical beliefs (Singh 2014, 165). 


\section{Situating (and mobilising) the self}

My own stable presuppositions concerning intersectionality, to the study of which I devoted the past decade of my life (Carastathis 2016), were informed by dwelling in different places - other worlds - than those through which my interlocutors are moving. The concepts on which I relied were, at times, compromised through travelling to the world of my interlocutors (Lugones 1987). I felt internally divided, uncertain of how to stand in "solidarity" in and through the articulation of my thought. For instance, I felt that, according to anti-racist principles of anglophone Black feminism, the use of "racism" as an umbrella term to describe homophobia and transphobia constitutes a misappropriation.

This research stems from multiple, and at times, contradictory desires: the desire of diasporic return; queer desire; the desire for social justice and subjective liberation; the desire for connection, mutual understanding, and community. These desires are interwoven with the migratory geography of my body's trajectories in space, its crossings and embodiment of multiple borders, its "circular migrations." ${ }^{1}$ On the one hand, these trajectories might classify this research in the ambivalent category of "anthropology at home" (Jackson 1987; Narayan 1993; Kuwayama 2003; Jahan 2014), because it occurs in the place I was born and lived during my childhood, where one of my two mother tongues is spoken, interspersed with loanwords from the other; but also because the community it seeks to encounter is one that feels familiar, due to my queerness and the ways in which it has shaped my affective and political affinities. On the other hand, given my emigration, as a child, and my absence from Greece for the past two and a half decades, my "mixed" ethnicity, my non-normative sexuality, and my feminist politics, my body is routinely perceived as "strange," or "foreign." On reflection, this ambivalent positioning has had interesting effects on the encounters staged in this research: I was simultaneously perceived as an insider and an outsider in interlocutionary spaces bordered by "movement," "community," "belonging," "authenticity," and "identity." In this sense, I was able to reflect on the dichotomy between "insiders" and "outsiders," "natives" and "foreigners" on which "anthropology at home" is based, and which, in its more sophisticated variants, it comes to problematize. I became interested in the ways in which these borders are contested through the phenomenology of migration, which is constituted by a heterogeneous multiplicity of subjective experiences and definitions of "belonging" and "nonbelonging," of narratives of the self, comprised of "roots" and "routes" (Hage \& Papadopoulos 2004). As Ghassan Hage writes, critiquing the opposition between mobility and immobility, of belonging and nonbelonging, travel and homeliness:

\footnotetext{
1 "Circular migration" refers to repeated migration between an "origin" and a "destination" and is usually ascribed to the temporary, repeated movement of a labour migrant between "home" and "host" countries. It is distinguished from "return migration" which involves a single emigration and subsequent return to the country of "origin," usually after a long absence. I use this term under erasure (hence the quotation marks), as, in what follows, I trouble the notions of "origin" and "home," and the politics and phenomenologies of belonging and nonbelonging that they articulate.
} 
One can move without belonging anywhere and feel confident and liberated doing so, and others move without a sense of belonging and feel brittle, shaken and exposed. We can even feel imprisoned by a state of constant mobility and belonging nowhere $(2004,115)$.

These reflections arose from an attempt to situate myself as a researcher vis-à-vis my interlocutors. I want to understand how movement attaches to language, the travel of concepts, and political mobilisation, and how we become attached to or mobilised by languages, concepts, and political ideologies. How does movement inflect and inform how we imagine liberation, particularly in contexts marked by crisis and displacement? In the conversations I invoke in this article, I try to show the multiple trajectories through which concepts are mobilised, some of which (like "racism") may appear rooted, while others (like "intersectionality") appear to be "recent arrivals," "newcomers," or even illicit "aliens."

\section{Queering "racism"}

In his article, «Homophobia as 'Racism' in Contemporary Urban Greece» (2009), based on his ethnography, Elsewheres: Greek LGBT Activists and the Imagination of a Movement (2005), Brian Riedel discusses the use of the word "racism" in Greek to indicate and describe homophobia. His point of departure is how, in his own context of anglophone North America, "racism" and "homophobia" are understood as two distinct, non-overlapping forms of prejudice, targeting two distinct social groups (Riedel 2009, 83). This point of departure is interesting for my purposes, given the ways in which the popular understanding of intersectionality in North America - as a multi-axial framework of oppression and identity - has disputed but also preserved the assumption that systems of oppression are ontologically discrete and analytically distinct, even if mutually constitutive or convergent in lived experiences. For instance, when Proposition 8 was passed in the U.S. state of California, banning same-gender marriage, The Advocate published a cover story titled "Gay is the New Black," declaring gay rights the "last great civil rights struggle" (Gross 2008). Such analogies were widely critiqued, not only because the construction of the U.S. as a "post-racial" society effaces the ongoing endemic racial violence of the state and its institutions; but also because the analogical structure of the slogan renders invisible gay people who are Black, and who face racism and homophobia simultaneously. Race-sexuality and race-gender analogies have a long history in U.S. social movement discourses and antidiscrimination law, where "race" and antiracism have a prototypical status vis-àvis other forms of oppression and discrimination. This prototypicality of antiracism seems to be operative in the Greek context as well, where, as Riedel observes, the word "racism" is used interchangeably with "homophobia" to describe anti-gay prejudice (Riedel 2009, 83). However, the reverse does not obtain, indicating the genericity of "racism" - contrasted to the specificity of "homophobia" - may account, in part, for this phenomenon of non-analogical, linguistic slippage or vernacular borrowing. 
Riedel tries to explain this slippage ethnographically through three axes of analysis: first, analysing loanwords in demotic, vernacular modern Greek, and their ascribed "Greekness" or "foreignness"; second, sketching how cultural constructions of homoeroticism have shifted in Greece in the post-dictatorship era (1974-?), and specifically through the emergence of an identitarian conception of sexuality; and third, tracing the effects on anti-racist discourse of an increase in immigration to Greece since 1990. His hypothesis is that two models of male homosexuality coexist in Greece at the turn of the millennium: on the one hand, a "traditional" or culturally prior schema dividing men who engage in penetrative homoerotic acts into two different gender roles: the "active" masculine "man" - versus the "passive" feminine "faggot"

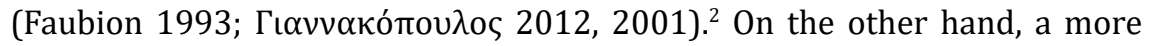
historically recent, identitarian construction of "western" origin views homosexuality as a minoritised identity in contraposition to the dominance of heterosexuality. Riedel argues that someone who perceives his sexuality in "traditional" terms is not likely to recognise himself as a target of homophobia, precisely because he does not identify as "homosexual" or "gay." That is, he does not view himself as belonging to that social category that homophobia seems to presuppose. Echoing findings of other anthropologists of sexuality (Apostolidou 2004; Kirtsoglou 2004; Kantsa 2010), Riedel found that activists militating for LGBT visibility and rights tended to reject the "traditional" construction of homoeroticism and struggled to destigmatise and make visible their marginalised sexual and gender identities.

This coexistence suggests something of a hypothesis about why ratsismós [racism] and omofovía [homophobia] continue to circulate in parallel, aside from the relative youth of omofovíaand the recognition ratsismósenjoys with its more inclusive definition. Those whose lives are not patterned after a politicised 'sexual identity' are less likely to participate in social circles where prejudice against homosexual practices and identities is spoken of as omofovía, a term they may find doubly foreign (linguistically and sexually). It seems reasonable to suppose that 'homophobia' as an analytic category will not overtake 'racism' until sociosexual identities significantly displace gender roles as the hegemonic organising trope of the same-sex sexual economy (Riedel 2009, 89).

Over a decade has passed since Riedel conducted his groundbreaking ethnography. Has such a displacement of "traditional" Greek by western "identitarian" constructions of homoeroticism taken place? Given that my research focusses on activist discourses, which Riedel hypothesises are overdetermined by identity politics, I cannot support such a generalisation. Many activists with whom I spoke characterised distantiation from sociosexual identities as a function of internalised homophobia. Some even implied that the "traditional" sexual economy was secretive and dishonest, a kind of culturally sanctioned closet. It enabled, in particular, "masculine" men, who were usually married to women - women whose sexual desires and practices, incidental-

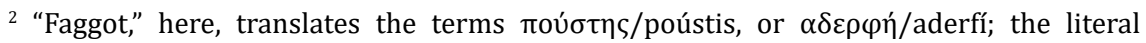
meaning of the latter is "sister."
} 
ly, remain off the radar in celebratory accounts of this economy - to act upon their desires without threatening, and while still benefiting from, compulsory heterosexuality. Moreover, the ascendancy of trans ( $\tau \rho \alpha \nu \varsigma /$ trans) and queer (кovíp/kouir) subjectivities in the intervening years has further affected the displacement of this "traditional" sexual economy. For a new generation of activists, "queer" has bridged the space between desire and politics in a way that Riedel's account does not foresee, enabling people at once to refuse to apply identity categories to their desires or sexual practices and, simultaneously, to politicise those desires and practices as a form of resistance to heteronormativity. Often converging with an anarchist political orientation, the anti-identitarian deployment of "queer" can be read, perhaps, as a response to some of the culturally constructed desires that inherit historical conceptions of sexuality, while resisting the ideological premises of transnational, hegemonic LGBT identity politics, especially its capitalist, nationalist, and homonormative commitments. The emergence of trans identities at once traces its local history in, and overtly rejects, the "traditional" model by insisting on an ontological distinction between "gender" and "sexuality" ( $\Gamma \alpha \lambda \alpha v o u$ 2014).

\section{Racism, strange and familiar}

It is not unusual to hear "racism" used in everyday conversations in Greek to mean hatred of or discrimination against various marginalised groups, some of which are not determined with respect to their membership in a "racial" category. Moreover, this usage is institutionalised: for instance, the law passed in 2014 criminalising hate speech directed against a person or group on the basis of "race, colour, religion, genealogical descent, ethnic origin, sex-

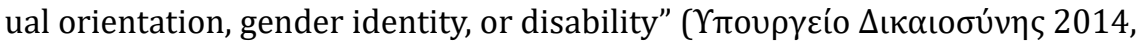
1 ) is known as the "antiracist law." Racism, in this usage, may target people with disabilities, gay, lesbian, transgender people, migrants, refugees, ethnic and religious minorities, HIV-positive people, workers, anarchists, or homeless people. At the same time, it is widely accepted that the concept of "racism" originates in reference to "races." Yet it is also not uncommon to hear the noun "racism" be modified with the adjective "racial" ( $\varphi \nu \lambda \varepsilon \tau \iota \kappa o ́ s ~ \rho \alpha \tau \sigma \iota \sigma \mu o ́ s, ~ f y l e-$ tikósratsismós). This redundancy implies the existence or salience of multiple racisms, only some of which are grounded in the construct of "race."

Despite having gained an emic character in Greek, it is an obvious mistake to attribute to "racism" linguistic autochthony or cultural authenticity, since it too (like "intersectionality," "homophobia," "transphobia," etc.) is a loanword introduced into political discourse through an earlier process of transnational and translinguistic conceptual travel. Indeed, this process is alluded to when, in contemporary discourse, phenomena of racism, racial violence, and racialised exploitation (for instance, against migrant field workers) are displaced from the "here" and "now" to other geopolitical spaces and historical times; paradigmatically plantation slavery in the U.S. South, or South African apartheid.

Racism, this "at first sight familiar term," famously gains an unfamiliar content in Michel Foucault's account of biopolitics and thanatopolitics, where 
it extends to any "distribution of human [beings] into groups, the subdivision of the population into subgroups, and the establishment of a biological caesura between [them]" (Mbembe 2001, 17). Foucault defines as "racism" the imposition of an ontological distinction between socially "alive" and socially "dead" populations - the differential construction of the targets of biopolitics and necropolitics (Athanasiou 2007, 21-22). Racism is crucial to the state's capacity to legitimate and enact its necropolitical sovereignty, that is, its right to determine "who is disposable and who is not" (Mbembe 2001, 27). Biopower is concerned with proliferating the latter, "to ensure population, to reproduce labor capacity, to constitute a sexuality that is economically useful and politically conservative" (Deutscher 2017, 76, citing Foucault). Racism, for Foucault, is the "basic mechanism" which, in a biopolitical age, resurrects the "power of sovereignty" introducing a "break between what must live and what must die" and is crucial to understanding the relationship of violence to valorisation and accumulation processes under capitalism (Foucault [1976/1997] 2003, 254, 265). Rejecting liberal philosophical views of sovereignty as self-institution and self-limitation, Achille Mbembe defines sovereignty as "the generalised instrumentalisation of human existence and the material destruction of human bodies and populations" (Mbembe 2001, 14). "In the economy of biopower," as theorised by Foucault, "the function of racism is to regulate the distribution of death and to make possible the murderous functions of the state" (Mbembe 2001, 17).

Foucault's account could be seen as a response to a problematic that has preoccupied critical race and postcolonial scholars for decades. Namely: "what could racism mean in the absence of race" as its ontological anchor? (McWhorter 2009, 42). It is interesting that as strange as Foucault's definition of "racism" may seem to a francophone or anglophone audience (which takes for granted the ontological - if socially constructed - connection between racism and "race"), in the empirical context under discussion, "racism" seems to be commonly used in a manner not so dissimilar to Foucault's usage. Yet, arguably in any language "race" has always carried an ontological ambivalence, not least of all due to the fact that it is a concept that tries to ontologise something unreal in order to justify racism. Defined as the perception of ethnocultural differences as "innate, indelible, and unchangeable," "racism" came into common usage in the 1930s, when a new concept was needed to describe Nazi theories; nevertheless, the phenomenon of racism preexisted the invention of the term we now use to describe it (Frederickson 2002, 5). Still, the meaning of "racism" has not been stable transhistorically. Racism is neither a transhistorical fact of social life nor a universal structure of the perception of alterity. Although some scholars locate its emergence in Western Europe in the 18th century, and specifically in the philosophy of Immanuel Kant, who was the first to defend a comprehensive theory of "racial difference" on which scientific racism was based (Kant [1777] 2000; Bernasconi 2001, 11; Eigen and Larrimore 2006, 3-4), other scholars argue that the equation of racism and racialist ideology with the Enlightenment, and specifically with theories that justify racial hierarchies in terms of biological differences, obscures the premodern past of racialisation (Loomba 2002, 38). As Ania Loomba sug- 
gests, in contrast to the tendency to interpret "racial difference" in positivist, biological terms that, in a sense, confirm and reproduce scientific racism, cultural and biological racisms always intersect in the production of "race" (Loomba 2002, 38). On the one hand, the early modern racialisation of religious, cultural, and linguistic difference (or, for that matter, the contemporary racialisation of Islam and Christianity) only partly converges with properly "racial" racism, understood to be based on differences are inherent, indelible, and immutable. On the other hand, the early modern prehistory of "race" may enable a wider use of "racism" beyond its narrowly "racial" dimensions. Since "race" lacks an ontological basis and instead invents one to legitimise slavery, colonialism, and white supremacy, perhaps this explains its use to indicate or refer to other configurations of oppression.

\section{Assemblages and the triptych of power}

The now disbanded collective Terminal 119 (2005-2013), in its prolific textual production and through its political interventions, synthesised antiracist, anti-authoritarian, anti-heteronormative, anticapitalist, antisexist, and anti-heteropatriarchal politics. When I met with them in the summer of 2015, I asked my interlocutors how they would define "racism."

Marco: "Racism" is a linguistic convention, "sexism" also, and all such terms. They are only names we came up with for things in order to communicate. Entirely conventional... I think we never attempted a definition... Alright, conventionally, in sociology, you can find definitions... But [racism] is something you can recognise when it's in front of you.

Nektarios: We like the concept of "racism" because, apart from naming the discrimination, it also calls out the perpetrator. And we like it because we attribute to the [perpetrator], because we live here - right? - in Greece, the perpetrator is in $99.9 \%$ of the cases ... he bears this patriarchal-nation-

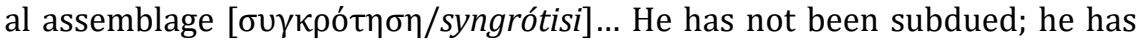
been incorporated into it and draws privileges from it ... And he treats a gay, a migrant, a Jew or a woman in the same way, drawing satisfaction precisely on the basis of this assemblage -

Marco: The Greek and the Other.

Nektarios: Yes. So, this is why we like [the term] "racism." Because it explains this, too. The term "discrimination" may be more conceptually correct sometimes, but "racism" has this added bonus [laughing] that it also calls out the perpetrator.

Anna: That is, it contains the notion of privilege?

Nektarios: Yes. This was kind of our motto in the group: "we will not deal with the victim of racism, we will deal with the perpetrator." The perpetrator interests us. We do not believe that by doing good deeds and helping a victim of racism we will do as much as we can [do] by naming the perpetrator.

Sani: Targeting the perpetrators.

Nektarios: Yes, exactly.

Sani: Or, focusing on the perpetrators...

Nektarios: For us, here, it's this: it's the Greek man and his privileges. This is racism. In Greece it is expressed like this... - 
Jenny ${ }^{3}$ : But then the need arises for a more intersectional [ $\delta\llcorner\alpha \theta \varepsilon \mu \alpha \tau \iota \kappa \eta$ / diathematikí] analysis. For example, we were reading Angela Davis writing about Black women in America; there, you need other... - yes, "racism" but they are Black women - the issue is more complicated. Or on the issue of transphobia, for example. And so, some needs are created over and above... Racism I don't know, branches out? But, perhaps, you need to use other words.

Anna: To specify what you are trying to describe?

Jenny: Because it's something else, it's something more. And so... [pause] Marco: Some power relations are more... they have their own characteristics. So when you go to analyse these characteristics, you have to get into more specific - what's it called? - categorisations... A division of analytical tools. But the most effective descriptions of racism and antiracism do not hinge on definitions, in my opinion; they hinge on describing practices ${ }^{4} \ldots$

Nektarios: What we said before: "look at the perpetrator." From transphobia to any sexual deviation from the dominant model - what is it? The dominant discourse is infection and the danger to the Greek family. You see it everywhere... That is where you will find condensations... the Greek family... condenses all that.

In the autumn of 2015, I spoke with three members of the gender/sexuality subgroup Fight Back! of Antifa Negative, which was formed in 2012 in Athens "by migrants and non-migrants," based on a founding text, a "Manifesto for an anti-Greek antifascism." (Antifa Negative 2012). In anti-authoritarian spaces in Athens, which tend to be male-dominated, heteronormative, and, while ideologically anti-nationalist, overwhelmingly culturally "Greek," Antifa Negative seemed exceptional in their effort to articulate an intersectional antifascist politics.

Haris: Just a hypothesis: because racism is predominantly conceived as a cognitive scheme ${ }^{5}$, that is, it is defined as prejudice ... so, immediately, "prejudice" is a more umbrella term, it refers to all other prejudices. Because people are not just biased towards foreigners, Roma, they are biased toward gays, disabled people, so there is ... this trajectory somehow connects them all through association, essentially. I, of course, disagree with that. I think it is reductive to link racism just in terms of prejudice, it psychologises it, it reduces it to a psychological thing - it does not add anything structural, power relations, it does not raise the issue of language, of racism and language... - What is bias, you know? Hostility plus poor categorisation.

\footnotetext{
${ }^{3}$ Although Jenny was not a member of Terminal 119, she was fortuitously present and contributed her insights from her own activist engagement to our conversation.

${ }^{4}$ To exemplify this claim, Marco quotes a passage from a poem written by a Black feminist that he remembers as "Forget that I am Black. Never forget that I'm Black." The Black feminist poet to whom he was referring is Pat Parker, who opens her poem titled "For the white person who wants to know how to be my friend" (1978): The first thing you do is to forget that I'm black. / Second, you must never forget that I'm black. The feminist collective Migada translated a selection of Parker's poetry into Greek and published in collaboration with the literary Teflon it as a brochure in 2014. They also translated Angela Davis' Women,

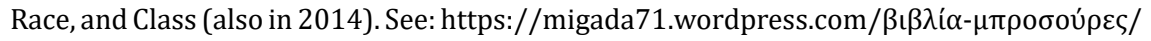
and https://teflon.wordpress.com.

${ }^{5}$ Words in italics were originally uttered in English by the speaker.
} 
I categorise and I hate ${ }^{6}$, let's say, in my mind...

Alexis: It's as if it's a logical... - an error in the collective... -

Haris: That's how they talk about racism from the beginnings of social psychology [according to this logic] ... I use "racism," generally, racism as an umbrella category that encloses homophobia and all that, but on the premise that I subtract from "racism" its partial content, i.e., breed [ $\rho \alpha ́ \tau \sigma \alpha /$ rátsa] / race $\left[\varphi v \lambda \eta^{\prime} / f y l i ́\right]^{7}$. That is, racism is not to hate someone based on their breed/race but -

Alexis: - Otherness.

Harris: Otherness, in general. So, one way or another, "racism" has taken this meaning from the moment that already in the sixties, the seventies anthropologists were saying, "fine, we have scientifically proven that the concept of race... - that there is no such thing as "race" -

Alexis: - "Race" -

Harris: - ...But Rabinow asks, "Why in the hell does racism persist after 'race' was scientifically deconstructed? Here we are making convincing arguments... But racism persists. Because the issue, simply, is not 'race'”?

Rea: Now the class analysis enters. [laughing] Watch out...

Haris: But the issue is that every form of Otherness can be understood as a foreign race... My grandfather used to say about Albanians, my late grandfather... - he didn't used to say they "are another race," he used to say, "they're of a different kidney, those people." This metaphor, he used it for one thousand two other things... Maybe he would say it for the gay men he saw on TV, you know?

Alexis: Or for civil servants, or whatever.

Haris: [laughing] Racism against civil servants in Greece of austerity... Joking. Do not write it in the minutes, please. We need some humour, at this stage, because otherwise we can't really handle it too well.

Anna: Still, this question of what remains of racism once the concept of "race" has been deconstructed, I think this differs somewhat from the claim that I can explain racialisation in alternative terms, e.g., in terms of class. The fact that race was constructed to legitimise racism does not mean that it can automatically be equated with another relation of power. And that is where the question lies for me: what you said before, about the isomorphism between various forms of oppression that are interpreted as personal intolerance, or as some individual bias, or as a psychological attitude, this isomorphism - which remains a question mark for me - is there really this isomorphism? If we do not interpret oppression in psychological terms, does an isomorphism obtain between the different forms of oppression? If, indeed, there are various forms of oppression, and it is not a [singular or unitary] thing that manifests itself in different ways.

Haris: It's an empirical question, I do not think we can answer it in this way... Within a specific context, we look at what power relations are at play, what axes... to see if there is isomorphism between them. I do not know if it can be answered -

Anna: - a priori -

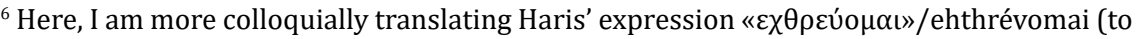
bear malice) to better capture the register of his speech.

${ }^{7}$ The more colloquial "rátsa" (a transliteration of the Spanish/Latin raza) is used mainly to refer to animal "breeds," in contrast to "fylí," which refers to human "races."
} 
Haris: Generally... In general, there is isomorphism - they are the same - to the extent that ... violence is the synecdoche of these things. Or, they are the same, to the extent that there is a subject on the other side for whom, whether you are a migrant or a faggot [ $\alpha \delta \varepsilon \rho \varphi \eta$ /aderfí], it is one and the same...

Rea: It is not absolute whether or not there is isomorphism, it depends on the person who has these characteristics or the person who feels hate for one or the other.

Haris: ...It's empirical.

Rea: Yes, it is, totally.

At this juncture, I gave the example of the diatribe of Ilias Panagiotaros, a Member of Parliament with the neo-Nazi party Golden Dawn, who was filmed during a demonstration against a performance of the play Corpus Christi in Athens, during which he characterised the actors as "screwed faggots, fucking

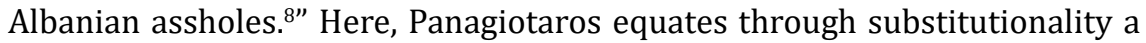
racist with a homophobic epithet. In another instance, a hierarchy between social groups is asserted, when fascists threw flyers in the neighbourhood of Gazi, a commercial gay village in Athens. The flyers read: "after the migrants, gays, you are next." In the first case, sexual/gender deviance is ascribed to a racialised group, while, simultaneously "faggots" are placed outside the borders of the nation. In the second case, a hierarchy - whether strategic or ontological - is implied. I shared with Rea, Haris, and Alexis how I understand the difference implied by these two examples of fascist hate speech:

\begin{abstract}
Anna: Either we are saying different systems come together to target a racialised migrant who is also gay... Or, we are saying that these oppressions are always already intermeshed and expressed relatively to the extent that someone has one or more of these identities, at least in the perception of the perpetrator, right? For me, these two things are somewhat different. And the question I posed about "racism" - I mean, about the use of the term "racism" is important to the extent that behind it, lies an analysis of this phenomenon that says it is hostility to Otherness; that is, all is the same and everything is interwoven together in advance. Or, is "racism" a word we use, perhaps for strategic reasons, to render the phenomenon visible for someone who may not have heard the word "homophobia" - which, I guess, entered our vocabulary relatively recently - while being familiar with "racism"?

Rea: I, personally, have not gotten into the logic of thinking about how a fascist creates hierarchies, what is more hateful and what less. So, I do not know what to say. I mean, I don't really think there's any point to it.

Anna: To some extent, there's no point. Let me put it a little differently and phrase it as a question ... Are oppressions multiple, or is oppression singular?

Rea: Oh! Multiple!
\end{abstract}

\footnotetext{
${ }^{8}$ While riot police watched, Church Patriarchs and believers of the Greek Orthodox Church joined forces with Golden Dawn fascists to attack the thespians and the audience during the performance of Terence McNally's Corpus Christi, which deals with issues of sexuality and Christian faith, depicting Jesus Christ and his apostles as gay men in contemporary

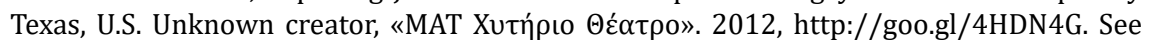
also Angélique Kourounis' documentary film, Golden Dawn: A Personal Affair, 2016, 1:30 minutes.
} 
Haris: They're multiple. But they come in a package -

Alexis: - in a value combo -

Haris: Yes, sometimes, in a value combo. They are multiple, multiple. But it is reasonable to think that, at any moment, someone feels multiple threats. What is the main concern - let's not say of the fascist, let's say of the patriot. The patriot's concern is that the country, the nation is safe... Because the nation has certain characteristics, the sources of insecurity are many: that is, the migrant, or the refugee threatens the borders, [threatens] public health in the city, will alter the culture, language; the homosexual comes as another threat: he threatens the reproduction of the nation, because he is gay, he does not care about the future of reproduction...

Anna: And if he cares, perhaps it's even worse.

Alexis: Yes, yes, yes, yes.

Haris: Yes, because he will break the model of -

Rea: Normativity -

Haris: The nuclear family -

Rea: Normality.

Haris: So, by entering the mind of the patriot, or the fascist, at the extreme, it is this: somehow, there threats exist everywhere and every threat strikes somewhat differently, each strikes another aspect in the image of who "we" are ... Women threaten...

Anna: Perhaps the hierarchy of the family?

Alexis: Mm.

Haris: Yeah.

Rhea: There are three values: nation, religion, family. The triptych of power.

\section{Intersectionality and identity}

My interlocutors tended to correctly (if rather vaguely) identify the roots of the concept of intersectionality in Black feminism, which is not at all a given in its academic routes of travel to other European contexts (Lewis 2013). In this regard, it may be significant that intersectionality did not travel to Greece through academic channels (the sole exception, to my knowledge, being Deligianni-Dimitrakou 2012), but through social movement discourses - to which discourses, admittedly, people educated abroad and/or people engaged in transnational social/activist networks, whether virtually or in real life, have contributed. This, combined with the local peculiarities of racialisation, migration, and "antiracist" politics characterising the Greek context, may account for an exception to the depoliticising, mainstreaming, and whitewashing of intersectionality that has been observed in Western, Central, and Northern European (academic) feminist contexts (May 2015). In Greek universities, feminist and gender studies are extremely marginalised, and critical race feminisms - including intersectionality - are virtually invisible. A significant exception with respect to the latter point is Athena Athanasiou's anthology, Feminist Theory and Cultural Critique (A $\theta \alpha v \alpha \sigma$ ó 2006), which includes translations of Evelynn M. Hammonds' "Toward a Genealogy of Black Women's Sexuality: The Problematic of Silence" (1997); Gayatri Chakravorty Spivak's "French Feminist Theory in an International Frame" (1981); Chandra Talpade Mohanty's "Feminist Encounters: Locating the Politics of Experience" (1987); and Gloria Anzaldúa's "La conciencia de la mestiza/Towards a 
New Consciousness" (1987). While Athanasiou discusses the "differentiation of the terms of oppression that structure women's experiences based on social class, race, ethnicity, sexual orientation, age, and physical ability" in her introduction to this anthology, she does not appear to invoke the term "intersectionality" ( $\delta\llcorner\alpha \theta \varepsilon \mu \alpha \tau \iota \kappa o ́ \tau \eta \tau \alpha /$ diathematikótita) or any other singular term to discuss this "central aspect of feminist theory in the 1980s," when "the theoretical and political challenge of not homogenising or objectifying the collective that feminist theory seeks to emancipate arises" (A $\theta \alpha v \alpha \sigma$ íou 2006, 35, my translation; see 32-39, 84, 114n21).

At its origins in Black feminist thought, intersectionality is a framework that makes visible the mutual exclusion of racism from misogyny in the construction of not only hegemonic categories - such as, for example, state-produced demographic categories of "race" and "gender"; but, also of subversive categories - such as, for example, social movement divisions between "anti-racism" and "feminism." Indeed, an intersectional approach reveals that not only the content but also the form of categories deployed by social movements reproduces hegemonic logic. The hegemonic logic of the social group: (a) focuses on the experiences and promotes the interests of a relatively privileged subgroup of the collective subject; (b) constitutes this relatively privileged subgroup as the prototype, essence, or centre of the group, identifying the entire group with its relatively privileged members; (c) misrepresents subjects who experience "multiple" oppressions (because they falsely divided from one another), since they are represented only to the extent that their experiences converge with the prototypical subgroup, their lives, struggles, and interests are distorted through fragmentation; (d) considers multiply oppressed subjects not to be representative of the group; their experiences are seen as more "complex" and their political loyalties "divided"; (e) and, finally, the hegemonic logic of the social group affirms a hierarchical theory of oppression, according to which one oppression precedes others (in severity, urgency, or causal priority). Intersectionality thus reveals, and contests, the fragmentation of lived experiences of simultaneous oppressions and the divisions among social movements and critical discourses, as a function of power and a form of representational violence.

The Black feminist legal scholar Kimberlé Crenshaw, in her landmark article "Demarginalising the Intersection of Race and Sex: A Black Feminist Critique of Antidiscrimination Doctrine, Feminist Theory, and Antiracist Politics" (1989), offers the metaphor of the accident that takes place in an intersection, for which no single driver can be held responsible: (a) to demonstrate how Black women's experiences are defined in terms of their sameness or difference to prototypical or normative members of the oppressed groups to which they belong: that is, Black men and white women; (b) to reveal that dichotomised, mutually exclusive definitions of racism and sexism render their experiences of oppression and discrimination invisible; and (c) to show how single-axis constructions of oppression fail to capture the full dimensions of racism and sexism, let alone effectively struggle against them (Crenshaw 1989, 149). In "Mapping the Margins: Intersectionality, Identity Politics, and Violence against Women of Colour" (1991), Crenshaw identifies three ways in 
$\frac{0}{0}$ which intersectionality can be deployed as a critical framework: (a) structurally: to reveal the interlocking nature of systems of power: race, gender, and class domination; (b) politically: to "highlight that women of colour are situated within at least two subordinated groups that frequently pursue conflicting political agendas" (1252); and (c) representationally: to demonstrate that in struggles over representational power, women of colour are objectified, instrumentalised, marginalised, spoken for and spoken over, as antiracism often becomes a pretext for misogyny and anti-sexism a pretext for racism (1292).

In "Mapping the Margins," Crenshaw is explicit that intersectionality is not "some new, totalising theory of identity" $(1991,1244)$. Yet, this is how intersectionality has been predominantly interpreted, as it came to mark a distinct, transnational field of study (Cooper 2015). Here it is important to note that in the translation of the term "intersectionality" to Greek, the metaphorical reference to the intersection is lost, while political intersectionality is highlighted: $\delta\llcorner\alpha \theta \varepsilon \mu \alpha \tau \iota \kappa o ́ \tau \eta \tau \alpha$, diathematikótita, is literally "inter-issuality," and may refer to the oft-quoted insight articulated by Audre Lorde that " $[\mathrm{t}]$ here is no such thing as a single-issue struggle, since we don't live single-issue lives" (1984: 263). Although diathematikótita places emphasis on (political) issues, rather than identity (politics), some of my interlocutors interpreted intersectionality as interchangeable with, or harnessed to a politics of identity, as exemplified in the following excerpts of my conversation with Yiannis, a member of Colour Youth, an LGBTQI+ youth non-governmental organisation.

When I asked Yiannis about how and when the term "intersectionality" entered social movement discourses in Greece, he referred to the influence of the International Gay and Lesbian Youth Organisation (IGLYO), part of the International Gay and Lesbian Association (ILGA) of Europe. In 2014, IGLYO held a training on intersectionality in Bologna, in which activists from all over Europe, including members of Colour Youth, took part. In 2015, ILGA collaborated with the European Network on Religion and Belief to hold a seminar on the "intersectional identity of the religious LGBT individual." But, during our conversation in the autumn of 2015, he also insisted that the need to invoke and address "intersectionality" arose with the "appearance, on their own, of intersectional identities themselves." I asked Yiannis what he means by "intersectional identities."

Yiannis: First of all, the intersectionality of sexuality and gender - right? because, when you're talking about, for example, a lesbian trans person, or a gay trans person, you understand that we're automatically talking about intersectionality. LGBT religious individuals had come to the group, and we had some issues... So, it was created on its own, the need to deal with intersectionality. So, because issues of gender and sexuality touch people's basic identities, but they are not the only ones that do, after a certain point, you cannot but start to see the interconnections that are created.

What prompted my question was a text written by Colour Youth titled "What kind of Pride do we deserve? What kind of community do we want?" in which they argue that: 
it is imperative, before we talk specifically about LGBTQ+ refugees' and/or migrants' issues, to refer to intersectionality; that is, the assumption that each person can have multiple identities that society pushes to the margins. All of us are different and our position is determined by the discriminations and privileges that society awards to individuals considered "normal": to white, cis, straight, well-off, able-bodied men. Many movements focus on one identity, as if this were the only source of oppression for those who bear it, thus, not giving basis for the problems of those who are experiencing further discriminations and exclusions; the result, ultimately, is that the most oppressed and vulnerable people are ultimately the most neglected $(2015,44)$.

\section{I asked Yiannis to elaborate.}

Yiannis: Look, in that particular text, since I too am looking at it now, it says that in the LGBT movement, attention to oppressions such as those facing migrant women, refugees, and people experiencing racial racism is lacking... In the organisation we also have members who, in the legal sense, as you say, are not Greeks. Who for $\mathrm{x}, \mathrm{y}$, or $\mathrm{z}$ reason, whether they are second generation, or whatever else, currently they don't have legal and political rights in Greece... More generally, a practice has prevailed that finds me very much in agreement, which is to give a podium to people who experience specific discriminations. What do I mean? I will not come out to tell you, as a white man, as a "Greek" (in quotation marks, as we've said) what racism is, in Greece today. Because whatever I may have read, as much as I may have followed the news, I might be able to tell you that racism exists, but I cannot tell you how it is being experienced. This text, then, is a plea: as a community, let us look at how we will be able to create the space for LGBT refugees and migrants to speak openly about precisely this kind of intersectionality. There, for me, is where the emphasis must be placed, and it is well-placed there, to the extent that it is. ... [W] ithout, of course, meaning that if there is no such person [present], you cannot talk ... about that. Because, obviously, and if I am asked my opinion about the oppressions experienced by LGBTQ people in Greece who are refugees or migrants, I can tell you some things. But I certainly cannot tell you how they are experiencing it, no. In the necessity for a political discourse to come out that can have an influence and bring about change, it is necessary to show from the outset your intention that, "I am making space for voices to be heard." And it's something Colour Youth does quite a lot. For example, Colour Youth has on its political agenda

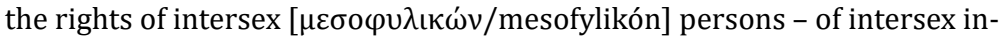
dividuals - but because we have very few intersex individuals - at least, ones who are out within the group but do not say it outward - we will be very careful about how we will approach outwardly a rhetoric of what intersex people are experiencing, and what the situation is in Greece, and so on. This holds true of all identities ... Essentially, you leave room so that certain identities can speak, without appropriating them. In this way, you give strength and foundation to the identity itself, and not to your own view of this identity. ... Colour Youth can come out and talk about the problems that LGBTQ migrants face, and does so to some extent, but as soon as an openly LGBTQI migrant/refugee shows up to speak, we will be silent. Do you understand what I mean? It's what's known as a "safe space," in the sense that what we can do at this moment in our own meetings is to create an environment where expressions of sexism, racism, homophobia, transphobia, and so on are not tolerated, so that this can be established as a space where 
identities and, especially, intersectional identities, can express themselves without fear of prejudice and negative attitudes that they face, one way or another, in society. This works to empower those people with this identity; obviously, if they want to talk openly and publicly about this identity it is clearly their own decision, but as an organisation, the least you can do is to provide this safe space.

This conversation took place in November 2015, after the so-called "Summer of Migration" and the emergence of a broad-based, international solidarity movement with refugees. It was not until 2016 that groups such as LGBTQI+ Refugees Welcome Athens, LGBTQI+ Refugees Lesvos, Eclipse/ Alkusuf LGBTQI+ Refugees Thessaloniki, began to be formed. However, as informal conversations with some activists engaged in these groups (to be expanded upon in a later stage of fieldwork) indicate, the response from the LGBTQI+ movement has been at times tokenising or marginalising of their voices ${ }^{9}$. An attempt at squatting a building for emergency women's and queer refugee housing was quickly quashed by police in the summer of 2016, but the rest of the refugee solidarity movement did not come out to publicly support the anarcha-queer squatters and protest the eviction (as it did, later that summer, protest a wave of other squat evictions in Thessaloniki and Athens). To what extent are vocabularies of struggle reflective of these missed opportunities for genuine queer coalitions, defiant of nation-state borders, including those sustained by heteronormativity?

Anna: I noticed in your texts that you use various terms, and I wanted to ask you how you perceive the broader use of "racism" - I mean of the concept of "racism" - in relation to terms such as "homophobia," "transphobia," "sexism," and so on. Is it clear what I am trying to ask?

Yiannis: Yes, essentially you're asking about the use of the term "racism" that you've noticed we use, but is also used generally in various contexts, and to what extent I believe that it is combined with "homophobia," "transphobia," and sexism," in particular through the prism, obviously, of LGBTQ activism, right?

Anna: Yes, exactly.

Yiannis: So, look, I think that this particular issue is quite complex, but while you were speaking, the first response that came to mind is that, actually, what many people claim is that homophobia, transphobia, and sexism are forms of racism. What do I mean: in Greece I think the definition - the word "racism" is used in a broader spectrum than in English, and it is no longer limited to discriminations due to ethnic origin, race, and so on. So, I think that "racism" in Greece is often in the context of intolerance and so on ... And, hence, in Greek - for example, the police, when they talk about a "racist motive" they include homophobia and transphobia, right? So, I think that "racism" has escaped the narrow sense it once had, and that "racism" has now been conceived as a more general situation, essentially, of relations of power towards a minority group or a minority identity, against the less powerful. This is just my opinion, right? I hadn't really thought about it, honestly.

\footnotetext{
${ }^{9}$ Personal communication with members of LGBTQI+ Refugees Welcome Athens.
} 
Anna: Nevertheless, you also often use the terms "homophobia," "transphobia," "sexism," and "racial racism." ... I'd be interested to hear your opinion as to what these concretisations do; that is, if they have a different effect than the deployment of "racism" as an "umbrella term."

Yiannis: Essentially, for me, what is the issue? It is that this division is needed to some degree. So, for me, it is very important that homophobia and transphobia are even mentioned in legal documents. And, okay, for me, that is to say, a person who is subject to precisely such discrimination...It makes an impression on me to be in spaces where homophobia is spoken of as form of discrimination. It has this kind of dynamic... Or, in essence, a recognition of experiences of individuals who are subject to these discriminations, it's true. Then, okay, you start and expand the list, because you're talking about racism, sexism, homophobia, transphobia, Islamophobia, fat-phobia, blah blah blah. Which, to a certain extent for me, they are necessary [terms], so it's good that we are referring to them. Of course, they also have some drawbacks, like... from having one term and everything was framed by it as discrimination, suddenly, it has become very specific, so a term can lose its forcefulness. One criticism we have received is, "It's great that you speak of homophobia and transphobia, but do not forget that most people do not understand what these words mean.» For example, if you consider the ety-

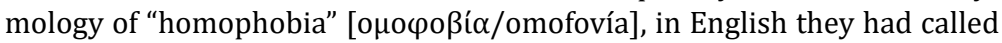
it homophobia, and in Greek, we took it as a loan, where "homophobia," as a word, essentially means «fear of the same. "So, the right term should be "ho-

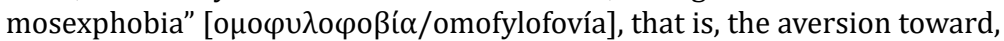
and fear of homosexuals, not toward the same, so-called "homophobia."

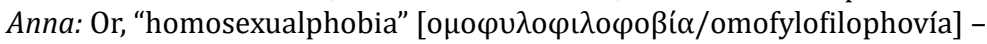
Yiannis: Right. Yes, that would be more grammatically correct. "Homosex-

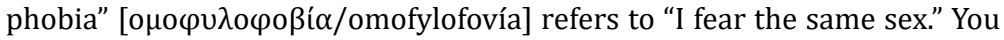
are right in that, yes. A similar issue is the following: since I take identity politics as a point of departure, increasingly, I'm being told, "What, another identity, what's going on?" And I'm like, on the other hand, for the people who feel this identity expresses them, it gives enormous power to have found an identity that expresses them. And then there is the logic of the movement, that it is losing its momentum, when the gay men go out to talk about their rights, the lesbians for their rights, the trans people for their rights, the bis for their rights, the intersex people for their rights... that is the reason I'm in favour of the fact that all of these have been put together in the same bag. Rights regarding sexual orientation, gender identity and expression, and the so-called "sexual characteristics"... So you understand, the issue has two sides, whether it's the issue of identities or the use of a generic word, like «racism» and its subcategories... Specifically for the word "transphobia," for example, it is incredibly important for such a community, whose rights are being continuously trampled, to refer very specifically to the term "trans" in "transphobia" - it is huge for a small, conservative society like Greece. I don't know if I've answered your question...

Anna: Yes. So, would you say that there is a dilemma - and maybe it's not a dilemma but a situation in which both coexist - between, on the one hand, of disintegration and specificity, and on the other, of unity and strength? Is that it? That is, on the one hand, if you use more specific terms, you give visibility to communities that are marginalised in society, or even within various movements, right?

Yiannis: Yes. 
Anna: But on the other hand, if you do not specify, and, let's say, you speak in general about "LGBT" rights, or even more generally about "antiracism," there is the danger that... - On the one hand, there is the positive side, that you are uniting different communities or different identities, but on the other hand, you lose this visibility afforded by more specific terms.

Yiannis: Exactly. Of course, then the question arises, where do you stop? So,

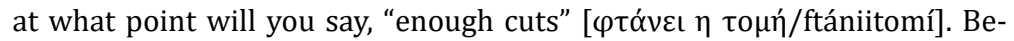
cause, theoretically, you can say it at any time... "that's enough now, though, because it is too complicated" - let alone now that a great many [identities] have emerged. It is related to the issue of where you use these terminologies, and I wanted to tell you: in a meeting of Colour Youth, for me, it is very important to refer to different identities and diversity. Because it empowers people [who have these identities] and informs other people. But when you address the outside [world] politically, you have to manage it quite

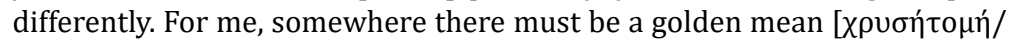
xrysítomí], which, of course, speaking about identities and about social and political rights, cannot be absolute, right? ... To put it very simply: when a specific struggle for trans rights takes place, obviously it should be led by trans people themselves, but the whole community should follow behind. This is the basic logic. That is, not [the logic of] absolute entrenchment

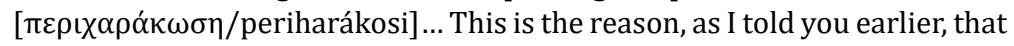
I am in favour of everything being put into the same bag, which makes for a very different dynamicity.

Gavriil, a member of the anarcho-queer collective Queericulum Vitae (2004-2015), which was disbanded not too long after our conversation in the summer of 2015, made a similar point about the visibility that the multiplication and specialisation of concepts - beyond the umbrella term "racism" - afford to marginalised subjects whose experiences of oppression are obscured in hegemonic discourses.

Gavriil: I think it's useful ... to have all these descriptions. In the sense that we are defined through discourse. Discourse usually describes an experience and it is important for this experience to be recorded ... with the features it has, because it's different for everyone, but it is significant for its voice to be recognised ... So, for me, it is especially important when it enters into speech ... into hegemonic speech. Because, I don't know... there's an attempt... to hide the targeted violence ... the reason why this happened. As occurred, for example, with the young guy who was lost... Parents, [television] channels, relatives concealed the reason ... [They] concealed the fact that this was the reason he disappeared ... For months, right? Like, ... "he was somewhat timid"; "his friends made fun of him"; "he was not man enough" ... Various descriptions circling around it, but without it being made clear that it was a homophobic attack. For me it was very important that this be recorded somehow in public space ... So, no, a broader "racism" does not work for me.

Here, Gavriil is referring to the death of a young college student, Vangelis Yiakoumakis, which, in movement discourses was denounced as a "murder by brave young men" [ $\lambda \varepsilon \beta \varepsilon \dot{v} \tau \varepsilon \varsigma /$ levéndes], referring to his continual torture 
by fellow students, which allegedly led him to take his life in early $2015^{10}$. As I discuss elsewhere, much of my conversation with Gavriil, as with all of my interlocutors, concerned the atmospheric transphobic and homophobic violence against which LGBTQI+ activists in Greece struggle, at the institutional, interpersonal, subjective, systemic, and also representational levels (Carastathis 2018). Gavriil, here, emphasises the importance of naming homophobic violence, rather than retreating into a generic discourse of "bullying," or appealing to a generic notion of "racism" that does not make visible the specificities of violence and the intersections of multiple systems of power in people's lives.

\section{Conclusion: travelling theories}

I cannot say that my ongoing conversations with activists engaged in LGBTQI+ movements in Greece have assuaged my hesitations about the risks of appropriation inherent in certain linguistic and discursive choices. On the one hand, the etymology of "racism" and the transnational history of antiracist and anti-colonial struggle seems to legitimise the exclusive use of the term to refer to oppressions based on "race" - or, rather, to oppressions that racialise their targets precisely in order to legitimise racism. Even if folk usage, in Greek, untethers this term from this meaning and attaches it to other oppressions and discriminations, are LGBTQI+ activists and other political agents justified in doing so? Some activists, such as the now disbanded femi-

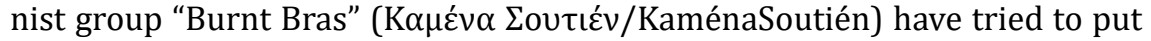
a stop to this linguistic/rhetorical practice, defining "racism" as "the system of power that structures social inequalities to the disadvantage of non-white people," and clarifying that "the term concerns only systemic inequalities on the basis of race and it is not correct to use it in other cases (e.g., 'racism against women' = wrong; 'sexism/misogyny' = right). We return, then, to the explanation of the generalised use of "racism" in terms of ignorance, error, or still worse - misappropriation. Moreover, does "racism," as an umbrella term, obscure the specificities of "non-racial" oppressions vis-à-vis "racial racism," which enjoys a prototypical status, or does it make them easier, transitively or analogically, for a broader public to acknowledge and denounce? Or, following Foucault, should we be asking a very different question: is there such a thing as a "non-racial" oppression in a biopolitical/thanatopolitical age?

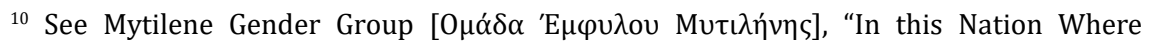

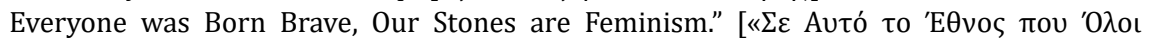

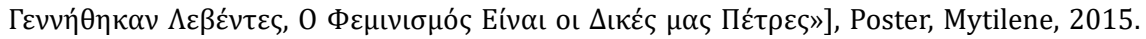
Antifa Negative/Fight Back!, “Don't Fall from the Clouds Every Week: (With Free Slaps

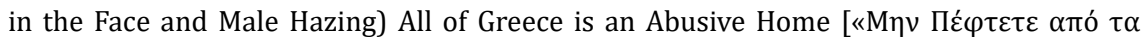

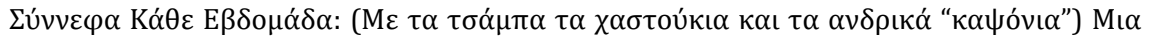

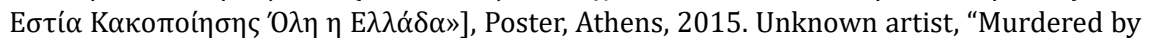

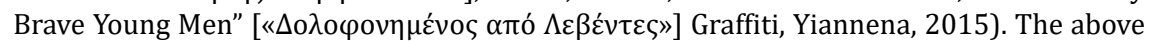

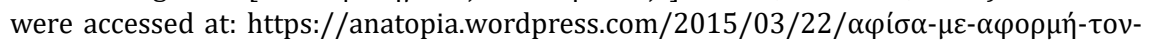
$\beta \alpha \gamma \gamma \varepsilon \dot{\lambda} \eta-\gamma \iota \alpha \kappa о u \mu \alpha ́ \kappa /$. A court case is currently being held where the accused face multiple charges, including homicide. 
On the other hand, questions of misappropriation also haunt intersectionality, a concept that has travelled from the racialised-gendered margins of U.S. social movements to the centre of transnational feminist scholarship and legal anti-discrimination discourse (Carbado et al. 2013). In my ongoing research, I am searching for ways to resist methodological nationalism, by examining not only how concepts cross various kinds of borders, but also how they, sometimes, serve to demarcate certain bordered spaces, and how attempts to territorialise, or claim ownership, autochthony, or authenticity are rhetorical moves that carry various risks. The question is not only, can we spatially map concepts as belonging somewhere, and not belonging elsewhere; but, also, how do concepts secure a sense of belonging for some, while functioning to estrange others? The question, broadly speaking, has been posed before: "How do theories travel?" (Said 1983). And: "how do theorists travel?" More specifically, "How do theories travel among the unequal spaces of postcolonial confusion and contestation?" (Clifford 1989) But, also, how do theories dwell or are refused stay in certain contexts? If concepts cross borders, are some migrations licit, while others are illicit? Matters of translation have ethical and political dimensions. Can even liberatory concepts be said to "colonise" our embodied imaginations - or, conversely, can they be "appropriated and resisted, located and displaced?" (Clifford, 1989; Puar, 2012: 54). When speaking of linguistic loans, do we only borrow words, or do we borrow concepts, discourses, representations, or embodied practices condensed in words? Is the loan a gift, or, must we repay the debt?

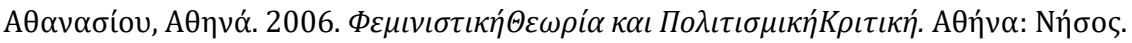

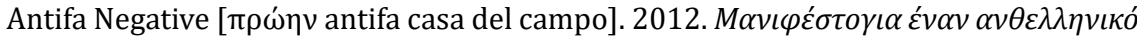
$\alpha \nu \tau \iota \varphi \alpha \sigma \iota \sigma \mu o ́, 12$ Maïou. http://antifa-ngt.espivblogs.net/?p=540.

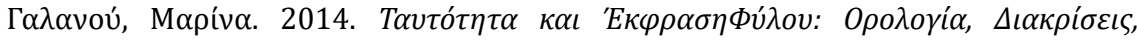

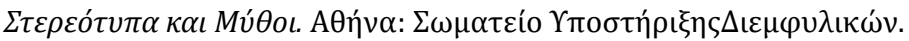

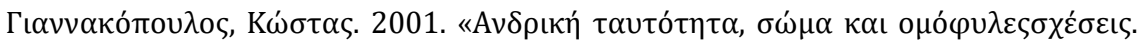

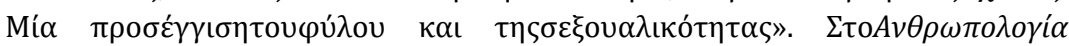

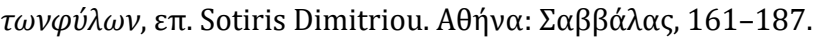

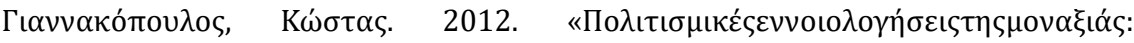

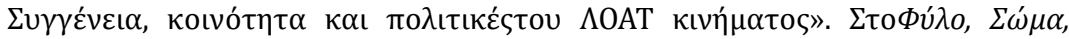

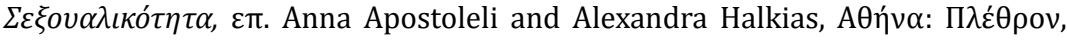
173-196.

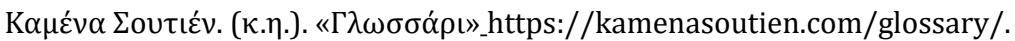

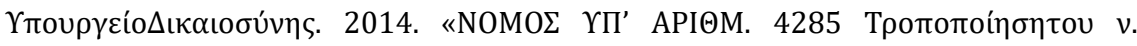

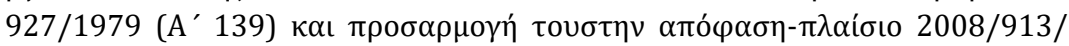

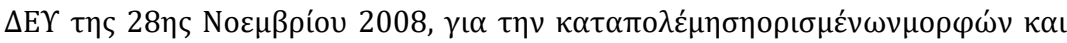

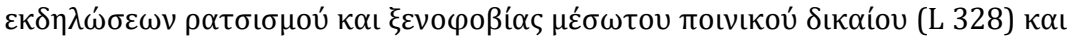

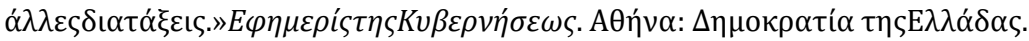

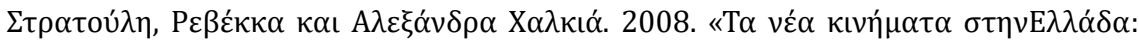

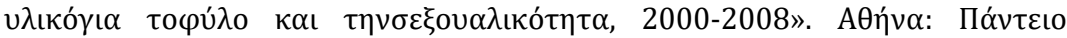

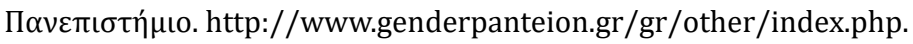

Apostolidou, Anna. 2004. Queering the Motherland: Disclosure Practices and Shifting Understandings of Male Homoeroticism in Greece. Ph.D. Dissertation, London: University of London (UCL). 
Bernasconi, Robert. 2001. "Who Invented the Concept of Race? Kant's Role in the Enlightenment Construction of Race." Race, ed. Robert Bernasconi. Malden \& Oxford: Blackwell, 11-36.

Carbado, Devon, Kimberlé Williams Crenshaw, Vickie M. Mays, and Barbara Tomlinson. 2013. "Intersectionality: Mapping the Movements of a Theory." Du Bois Review 10 (2): 303-12.

Carastathis, Anna. 2016. Intersectionality: Origins, Contestations, Horizons. Lincoln \& London: University of Nebraska Press.

Carastathis, Anna. 2018. "'Gender is the First Terrorist': Homophobic and Transphobic Violence in Greece." Frontiers: A Journal of Women's Studies 39 (2): 265-296.

Clifford, James. 1989. "Notes on Travel and Theory." Inscriptions 5. http://criticaltheoryindex.org/assets/cliffordjamestraveltheory.pdf.

Crenshaw, Kimberlé Williams. 1989. "Demarginalizing the Intersection of Race and Sex: A Black Feminist Critique of Antidiscrimination Doctrine, Feminist Theory and Antiracist Politics." University of Chicago Legal Forum 140: 139-67.

Crenshaw, Kimberlé Williams. 1991. "Mapping the Margins: Intersectionality, Identity Politics, and Violence against Women of Color." Stanford Law Review 43 (6): 1241-99.

Cooper, Brittney. 2015. "Intersectionality." The Oxford Handbook of Feminist Theory, eds. Lisa Disch and Mary Hawkesworth. Online publication date August 2015. doi: 10.1093/oxfordhb/9780199328581.013.20.

Das, Veena Michael Jackson, Arthur Kleinman and Bhrigupati Singh. 2014. "Introduction: Experiments between Anthropology and Philosophy: Affinities and Antagonisms." The Ground Between: Anthropologists Engage Philosophy, eds. Veena Das, Michael Jackson, Arthur Kleinman and Bhrigupati Singh. Durham\& London: Duke University Press, 1-26.

Deutscher, Penelope. 2017. Foucault's Futures: A Critique of Reproductive Reason. New York: Columbia University Press.

Eigen, Sara and Mark Larrimore. 2006. "Introduction." The German Invention of Race, eds. Sara Eigen and Mark Larrimore. Albany: SUNY Press, 1-10.

Hage, Ghassan and Dimitris Papadopoulos. 2004. "Migration, Hope and the Making of Subjectivity in Transnational Capitalism." International Journal of Critical Psychology 12: 107-121.

Faubion, James. 1993. "Men Are Not Always What They Seem: From Sexual Modernization Toward Sexual Modernity." Modern Greek Lessons: A Primer in Historical Constructivism. Princeton \& London: Princeton University Press, 213-241.

Foucault, Michel. 1976/1997/2003. Society Must Be Defended: Lectures at the Collège de France 1975-1976. London and New York: Verso.

Foucault, Michel. 1975/1999/2003. Abnormal: Lectures at the Collège de France 19741975. London and New York: Verso.

Frederickson, George M. 2002.Racism: A Short History. Princeton \& Oxford: Princeton University Press.

Gross, Michael Joseph. 2008. "Gay Is the New Black?" The Advocate, 16 November. https://www.advocate.com/news/2008/11/16/gay-new-black.

Jackson, Anthony, ed. 1987. Anthropology at Home. London: Tavistock.

Jahan, Ishrat. 2014. 'Revisiting 'Nativity': Doing 'Anthropology at Home' in Rural Bangladesh." Anthropology 2 (3): 1-8. 
Kant, Immanuel. 1777/2000. "Of the Different Human Races." The Idea of Race, eds. Robert Bernasconi and Tommy Lott. J.M. Mikkelsen (trans). Indianapolis: Hackett, 8-22.

Kantsa, Venetia. 2010. “Vizibility': Women, Same-Sex Sexualities and the Subversion of Gender." Journal of Mediterranean Studies 18 (2): 213-240.

Kirtsoglou, Elisabeth. 2004. For the Love of Women: Gender and Gay Identity in a Greek Provincial Town. London: Routledge.

Kuwayama, Takami. 2003. "'Natives' as Dialogic Partner: Some Thoughts on Native Anthropology." Anthropology Today 19 (1): 9-13.

Lewis, Gail. 2013. "Unsafe Travel: Experiencing Intersectionality and Feminist Displacements." Signs: Journal of Women in Culture and Society 38 (4): 869-916.

Loomba, Ania. 2002. "The Vocabularies of Race.” Shakespeare, Race, and Colonialism. Oxford \& New York: Oxford University Press, 22-44.

Lorde, Audre. 1984. Sister Outsider: Essays and Speeches. Freedom: Crossing Press.

Lugones, María. 1987. "Playfulness, 'World'-Travelling, and Loving Perception.” Hypatia 2 (2): 3-19.

May, Vivian M. 2015. Pursuing Intersectionality, Unsettling Dominant Imaginaries. New York and London: Routledge.

Mbembe, Achille. 2001. “Time on the Move." On the Postcolony. Berkeley \& Los Angeles, University of California Press, 1-23.

McWhorter, Ladelle. 2009. Racism and Sexual Oppression in Anglo-America: A Genealogy. Indianapolis: Indiana University Press.

Narayan, Kirin. 1993. "How Native is a 'Native' Anthropologist?” American Anthropologist 95 (3): 671-686.

Puar, Jasbir, K. 2012. "'I would rather be a cyborg than a goddess': Becoming-Intersectional in Assemblage Theory." philoSOPHIA 2 (1): 49-66.

Riedel, Brian Scott. 2009. "Homophobia as 'Racism' in Contemporary Urban Greece." Homophobias: Lust and Loathing Across Time and Space, ed. David A.B. Murray. Durham and London: Duke University Press, 82-102.

Riedel, Brian Scott. 2005. Elsewheres: Greek LGBT Activists and the Imagination of a Movement. Ph.D. Dissertation. Houston: Rice University.

Roseneil, Sasha, Isabel Crowhurst, Ana Cristina Santos and Mariya Stoilova. 2013. "Reproduction and citizenship/reproducing citizens: editorial introduction." Citizenship Studies 17 (8): 901-911.

Said, Edward. 1983. "Travelling Theory." The Text, the World, and the Critic. Cambridge: Harvard University Press, 1983.

Singh, Bhrigupati. 2014. "How Concepts Make the World Look Different: Affirmative and Negative Genealogies of Thought." The Ground Between: Anthropologists Engage Philosophy, ed. by Veena Das, Arthur Kleinman, Michael D. Jackson, and Bhrigupati Singh. Duke University Press, 159-187.

\section{Annex: Conversations Cited}

Conversation with Gavriil (Queericulum Vitae). Athens, 4 July 2015, 90 minutes.

Conversation with Marco, Nektarios, and Sany (Terminal 119) and Jenny. Amphipolis, 21 August 2015, 114 minutes.

Conversation with Alexis, Haris, and Rea (Antifa Negative/Fight Back!). Athens, 28 October 2015, 160 minutes.

Conversation with Yiannis (ColourYouth). Lisbon/Athens (via skype), 5 November 2015, 141 minutes. 


\section{Queering Bratislava: On Borders, Otherness and Public Space}

Arriving at each new city, the traveller finds again a past of his (sic) that he did not know he had: the foreignness of what you no longer are or no longer possess lies in wait for you in foreign, unpossessed places.

Italo Calvino, Invisible cities, 1972

\section{Arriving in Bratislava}

$\mathrm{T}$ his paper is the outcome of my 3-year scholarship at the Institute of Sociology in Bratislava that began in September 2015. I had never visited Bratislava before this fellowship, and admittedly my limited knowledge about the city derived from a small number of scholars that work in the field of post-socialist urban studies (Hirt 2012; Todorova and Gille 2010; Fejes and Balogh 2013). The research project - Sociology of Crisis: Visualising Urban Austerity - that brought me to Bratislava is an investigation into some of the core problems faced by sociological perspectives on crisis and austerity. Using methods from visual and urban sociology - social vignettes, photography workshops, walking interviews - it tackles the dual crisis of representation: both the political crisis of loss of faith in representative democracy as well as arguments about the partial, time-bound, subjective frame of photographic representations (Tsilimpounidi 2017).

The core focus of my project is the notion of crisis and how this shapes European societies and sensibilities. Having done extended research in the European South on the post-2008 financial crisis and especially in my home city of Athens; I have also witnessed the after-effects of the financial crisis in the UK where I lived for the last decade of my life before arriving in Bratislava. From 2012 onwards there was a plethora of symposia, conferences, journal articles, media reports, and documentaries trying to make sense of the unfolding realities of the European financial crisis. Almost all of them compared the European North to the European South and in some cases reproduced quite problematic stereotypes in order to explain one more failure of the capitalist system. A quite mainstream (conservative and racist) approach insisted 
$\frac{0}{0}$ that the problem lies in the division between the effective, law abiding, and hardworking North and the tax evading, lazy and corrupt South (Douzinas 2013; Christopoulou 2014). There were discussions in the European parliament referring to the European PIGS (Portugal, Italy, Greece, Spain), an acronym that indicated countries in South Europe that were facing economic stagnation and their economies were hit hard by the post-2008 crisis. Certain nations were seen as responsible for the unbearable economic conditions in the EU; Greeks, in particular, were seen as the prodigal children of Europe that had to be 'kicked out' of the union (Zaroulia and Hager 2014).

Following this logic, it comes as no surprise that racist, xenophobic, and nationalist discourses were empowered all over Europe. The obvious explanation was that crisis brings unemployment, further marginalisation of certain strands of the population, and, poverty; therefore, crisis paves the way for the reawakening of xenophobic and racist ideologies in Europe. Well, even if this is partly true, we need to be suspicious of such cause-and-effect explanations when it comes to deep-rooted social phenomena such as racism and xenophobia. Moreover, what was striking in the European reportage on crisis was the absence of Central-Eastern European perspectives, from the usual comparison between the European North and South. Yet, in CEE the effects of the economic crisis were milder and, in some cases, like Bratislava, development ratios were improving in the midst of the European crisis. Yet, despite the financial improvement, xenophobia and racism were empowered in Slovakia as well. So, my intention was to include CEE in the comparison between the European North and South, in order to dismantle some of the prevailing stereotypes surrounding crisis discourse. For example, xenophobia and racism were not the outcomes of the post-2008 financial crisis in Europe, instead, these tendencies were always there, but in the moments of prosperity they were more easily masked. Europeans did not wake up suddenly in a xenophobic and racist Europe; this was the outcome of years of exclusions of unwanted others and internal dynamics from the beginning of the formation of the union.

So, I arrived in Bratislava with the intention to draw comparisons between perspectives from Southern and Northern Europe with Central European cases in order to dismantle some of the stereotypes surrounding the milieu of crisis. My project was mainly focused on the post-2008 financial crisis, yet I arrived in Bratislava in September 2015 just after 'the summer of migration' in Europe. In other words, my arrival coincided with a second crisis for the European project, what has been named 'the refugee crisis'. It was a moment of extreme polarities and tensions, but also a milieu open for engaged (and enraged) sociological research.

Interestingly enough there were many points of similarity between the two consecutive European crises - the financial and the refugee. Again, uncritically, the mainstream media reproduced a discourse that leaves no room for critical reflections on the true causes of the crisis. According to this mainstream narration the beginning of the refugee crisis coincides with the ap- 
pearance of certain bodies on the European shores. Almost implying that the cause of the refugee crisis are those certain bodies, completely downplaying the violence of civil war, military interventions, and daily bombings of Syria for example. In other words, people fleeing war were portrayed as the cause of the problem and not the fact that France, the UK (together with the US and Russia) were continuing the distraction of Syria. War was not the problem, human suffering was not an issue; yet, the presence of certain bodies was the beginning of the European refugee crisis. Similarly, with the financial crisis, years of intensified inequalities between the 'rich' and the 'poor' strands of populations was not the problem, the ethics of turbo-capitalism and the fixation to profit-making was considered as 'business as usual', yet certain European countries were to blamed (especially Greece) and certain nations were to suffer the implementation of austerity policies.

Upon my arrival in Bratislava, Greece was portrayed as the epicentre of both crises: the lazy tax-evading nation of the South responsible for the financial crisis in Europe, but also the entrance gate of refugees to Europe and the 'hot-spot' of the continent (Carastathis, Spathopoulou and Tsilimpounidi 2018). I felt it was a particularly charged moment to 'be Greek' in Slovakia, not that I self-identify with any nation-state but since I was always perceived as anon-native in Slovakia one of the first questions posed to me was the whereabouts of my origins. The answer was not always received nicely, and I have witnessed many racist outbursts once my nationality was exposed. In what follows, I engage with this enraged sociological scholarship in an attempt to offer a short provocation on the bridges between post-socialist urban studies and queer theory through a series of 3 vignettes of Bratislava.

\section{Queering Bratislava}

Bratislava has undertaken multiple, rapid transitions in a compressed period of time. Being a threshold of passages, while struggling to establish a national urban identity, Bratislava exemplifies the vast transitions that exploded in Eastern Europe after 1989, but also the accelerated, accumulative capitalist realities that point towards the necessity for post-capitalist imaginaries both in theory and in practice. As a post-socialist city, it represents the transition from state socialism after 1989 to democracy and neoliberal capitalism. The fall of the iron curtain harnessed public aspirations for the unifying project of the European Union. Yet, even the use of the term post-socialist as descriptive of Bratislava should be contested, firstly because it presupposes the presence of a former 'socialist city' and secondly because in a way it distinguishes this urban environment from a capitalist city, which is not valid in the case of Bratislava.

While, twenty-five years later, some scholars have declared the end of the 'post-socialist' transition (Ferenčuhová 2011), others argue for the continued (or renewed) significance of the axis of differentiation between 'West' and 'East' in emerging geopolitical conditions. Matej Blazek and Pavel Šuš- 
$\frac{0}{0}$ ka have proposed 'a dialogic approach to post-socialism [...] characterised by a radical ontological openness in which no single solution takes primacy. It is constructed in a dialogue with various pasts, presents and (envisioned, anticipated, planned, and evolving) futures, and formed by a multiplicity of geographical connections that can never formulate a steady holistic identity' (Blazek and Šuška 2017, 48). They suggest that a non-teleological model of post-socialist transition, which neither reduces East-West unification to a mimetic process, nor reproduces an essentialist discourse of cultural and political difference can account for tensions along the East-West axis concerning issues such as the 'Refugee Crisis in 2015, the Russian invasion of Ukraine in 2014, LGBTQ rights, and intra-EU migration' (Blazek and Šuška 2017, 46).

This paper follows the multiple layers of an urban fabric that is stereotypically characterised as 'post-socialist', yet in essence it is subject to ongoing transitions - much like the notion of being queer-in order to pose the question: What can we learn from queer theory in relation to post-socialist urban theory? The transition from socialism to capitalism is often represented as an exodus to the promised land of economic prosperity and political freedom. Yet, within capitalism there have been multiple transitions, sometimes signified through the now-hegemonic concept of 'crisis'. The symptoms of capitalist crisis conjure collective memories of austerity in the post-socialist social imaginary; yet, they can coincide with accelerated destruction and development of the urban fabric through transnational investment and financial speculation.

In other words, in a similar way that queer studies attempt to carve a space for thinking differently about the relations presumed to exist between binary models and systems-for example, between sex and gender; or gender and sexuality-we could attempt to scholarly queer Bratislava and disassociate ourselves from the binary model of transitions between fixed categories, namely the post-social and the neoliberal, or the communist and the democratic. As Eve Kosofsky Sedgwick notes in one of the earliest definitional attempts of the notion of queer theory:

That's one of the things that 'queer' can refer to: the open mesh of possibilities, gaps, overlaps, dissonances and resonances, lapses and excess of meaning when the constituent element of anyone's gender, of anyone's sexuality are not made (or cannot be made) to signify monolithically (Sedgwick 2013, 8).

In this light, queering Bratislava means to be open to the different speeds and dynamics of transitions, and at the same time embrace both theoretically and methodologically the complexity of categories that were previously thought as fixed and monolithic. Moreover, it points towards an intersectional model of analysis that does not separate the city's transitions from the lived experiences of its people and thus from other axes of power and social differences, such as race, ethnicity, class, and gender. For example, ethnic minorities such as Roma had a completely different experience of the 1989 transition than Slovak citizens; and even amongst Slovak citizens there was a huge division between urban and rural experiences of certain crucial 
and historical moments. Thus, queering Bratislava also means to take a marginal standpoint in an effort to make the margins a space for academic (and activist) learning.

What could then be the methodological advancements that derive from such an approach? This paper will attempt to break the usually logocentric academic discourse and engage with the premises of visual sociology. As evident in the etymology of the Greek word theoria, theory is the establishment of a point of view; it involves the act of looking from a particular place, and from there making a leap into analysis of the wider interrelationships of events. If seeing comes before words (Berger 1977), then there is a fundamental connection between visualisation and our being in the world. However, our ways of seeing are dependent not only on our positionality but also on the available discursive framings. Using visual material from Bratislava focusing on urban inscriptions (street art, urban interventions) it opens up a discussion about the changes in the city and the struggles of different groups. What remains visible in the public space of a city? What should be concealed?

In what follows, the paper explores the visual economy of subversive 'signs' in order to re-claim public space and the visual as a territory of queer resistance. The three vignettes and the images that accompany them were chosen not as a way to define the city, but as a point of further evocation of the multiplicity of borders, identities, and performances of belonging that characterise Bratislava. Despite the apparent realism of photography as a medium, the visual materials are not designed to provide a uniquely authentic account of the city, but rather to offer a more in-depth understanding, from a visual perspective. As Chris Jenks has postulated, 'both seeing and social theory are acts of interpretation: selection, abstraction, and transformation. Both are socially constructed and culturally located' (Jenks 1995, 210). I thus acknowledge the subjectivity inherent in both taking the photographs and selecting them to accompany this paper.

\section{Queer historicity: past/present/future}

Time is inextricably bound up with notions of progress, growth and development. What are the changing notions of time and historicity and its socio-political effects in moments of crisis and rapid social change? After my initial engagement with lived realities, daily practices and informal discussions with friends and colleagues in Bratislava, I realised that the linear contract of time was broken in their narrations. Time was out of joint, historical moments seemed fragmented, and sometimes it seemed to me that there was no clear direction or outline for a future set of circumstances. The past was experienced through the wound of the communist regime; it was something that in many cases remained unspoken, unsaid, and therefore unquestioned. So, the present was trapped in this wound, the historical trauma was such that the present was simply the time to avoid by all means a return to the past. This notion of the haunting past was so prevailing that left almost no imag- 
$\frac{0}{0} \quad$ ining possibilities for the future. Any notion of leftist politics or commoning practices was easily dismissed through the juxtaposition with the past. The

$\varangle$ linear contract of time was broken. The past. The present. The past. The past. Always the elimination of the past.

But the future was already here, looming large, setting in motion a different set of transitions: aggressive gentrification in the city-centre, demolition of buildings and monuments that were connecting the city with its past, Disneyland touristification, and the promise of a capitalist dream. There is a sense of loss, a lost future, a vacuum of history, a fragmented collection of Western-style era of really (really!) late capitalism that elsewhere in Europe was in crisis. Big corporations moving their offices and headquarters in Bratislava; I've seen this happening before in a different past of mine. Time is money! Time is progress. Are people in Bratislava experiencing now the reboot of history? Is history watching them now, or was it watching them only after 1989? Time is money and capitalism has its own rhythms. New high-rise buildings are taking the place of old houses; big corporations are buying local businesses; favourite underground venues are closing down due to expensive rents. There is a great future ahead! But most of the residents of Bratislava I spoke to, cannot afford living in the city-centre, they cannot find places to entertain themselves in the centre and feel alienated. Living costs are rising, but their salaries are not. Perhaps, as the artistic collective Depression Era ${ }^{1}$ puts it 'they have a great future behind them'!

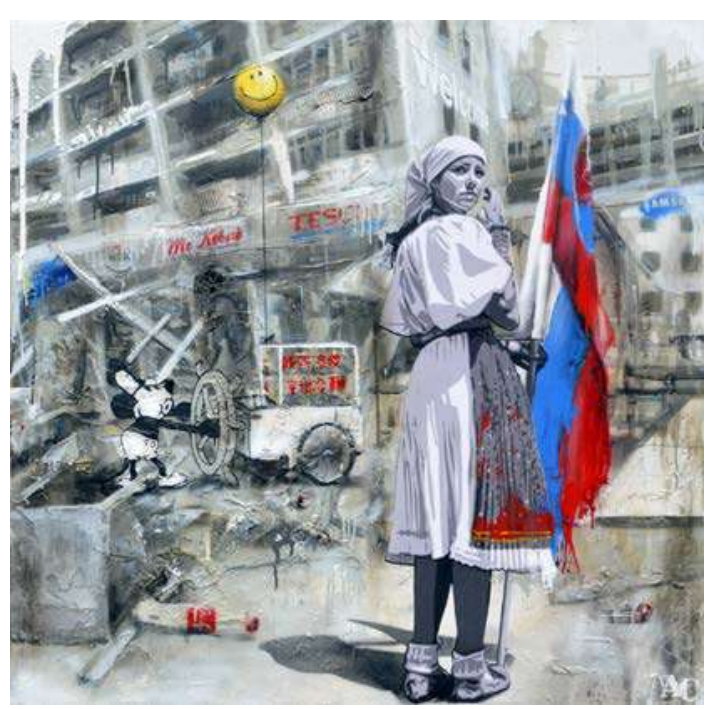

'Lost', Artist: AC-one, 2016; reproduced with permission

The artwork is made by Ac-one ${ }^{2}$, my favourite graffiti writer and street artist in Bratislava. He titled this artwork 'Lost' in order to signify how young people (his generation) feel about their identity, their belonging, and their future. The main character is a traditionally dressed Slovak woman holding the Slovak flag. She is lost and skeptical about where to go, she is looking behind her shoulder towards 'us'. In front of her a process of

\footnotetext{
${ }^{1}$ This slogan derives from a poster campaign that the collective launched in 2017 which can be found here https://depressionera.gr/tourists.
}

${ }^{2}$ For a full appreciation of Ac-one's work: https://www.ac-one.com. 
extreme gentrification has started, a rapid speed metamorphosis of the urban landscape, and emblematic trademarks of this style of capitalism are visible: a Coca Cola bottle, a Tesco sign, Micky Mouse, etc. I cannot stop thinking of Walter Benjamin and his analysis of Paul Klee's painting the 'Angelus Novus'.

According to Benjamin's analysis, a Klee painting named 'Angelus Novus' shows an angel looking as though he is about to move away from something he is fixedly contemplating. His eyes are staring, his mouth is open, his wings are spread. This is how one pictures the Angel of History. His face is turned toward the past. Where we perceive a chain of events, he sees a single catastrophe which keeps pilling wreckage upon wreckage and hurls it in front of his feet. The angel would like to stay, awaken the dead, and make whole what has been smashed. But a storm is blowing from Paradise; it has got caught in his wings with such violence that the angel can no longer close [...] This storm irresistibly propels him into the future to which his back is turned, while the pile of debris before him grows skyward. This storm is what we call progress (Benjamin 1968, 257-258).

Ac-one has offered us a visualization of the Slovak angel of history in the era of capitalist transformations and fragmented time. In our discussion, I ask him why the central figure of his work is a woman. We talk about gender dynamics in the Slovak society and how he thinks that especially women are trapped in traditional roles and stereotypes. He and his collaborator are wondering whether there is any chance is modernising tradition or the only way forward is through the ruins of the past. ${ }^{3} \mathrm{~A}$ few months after our discussion I spent Easter Monday in Slovakia and I witness first hand a folklore ritual of throwing cold water and whipping women on that day from 6 am in the morning. The men who are performing the task are congratulated with a shot of alcohol. Needless to say that the ritual is performed in order to offer more fertility to the women! ${ }^{4}$ I remember Ac-one's piece as I think of all the normalised violence that wears many guises on our everyday encounters. The woman in the picture seems lost, her traditional costume slightly destroyed, and when I observe the image closely it seems to me that she is also cold, wet, and in pain from the accumulation of many Easter Mondays on her body.

\footnotetext{
${ }^{3}$ This is based on an interview and an informal discussion with Ac-one and his collaborator in 2016.

${ }^{4}$ Easter whip, a tradition of spanking or whipping, is carried out every year on Easter Monday. In the morning, men spank women with a special handmade whip called korbáč, which consists of twelve withies (willow rods) and is usually one meter long and decorated with coloured ribbons at the end. The spanking may be painful, but it's not intended to cause suffering. A legend says that women should be spanked with a whip in order to keep their health, beauty and fertility during the whole next year (Wikipedia entry on 'Easter whip').
} 
Fragmented time relates to fragmented identities. Many activists in Bratislava expressed their frustration over the alienation and the difficulty of sustaining meaningful and interventionist politics. They spoke about feelings of general apathy towards politics and political forms of organisation. We had many (usually) late night discussions about the difficulty of relating their politics to anything that could be associated with the past, whether that was a discourse of the commons or commoning practices of reclamation of urban space. A series of transitions and crises has a particular after-effect on social dynamics, I think of Naomi Klein here and her notion of the Shock Doctrine (2007). Klein argues that the implementation of neoliberal free market policies happens after a shock to the national consciousness. A shock can take many different forms - economic crisis, terrorist attack, national disaster, or let's say fear mongering after the 'refugee crisis'. This deliberate strategy used by the state in order to implement oppressive legislation utilises shocks and crises in order to push through controversial policies while the population feels fear, distraction, and disorientation.

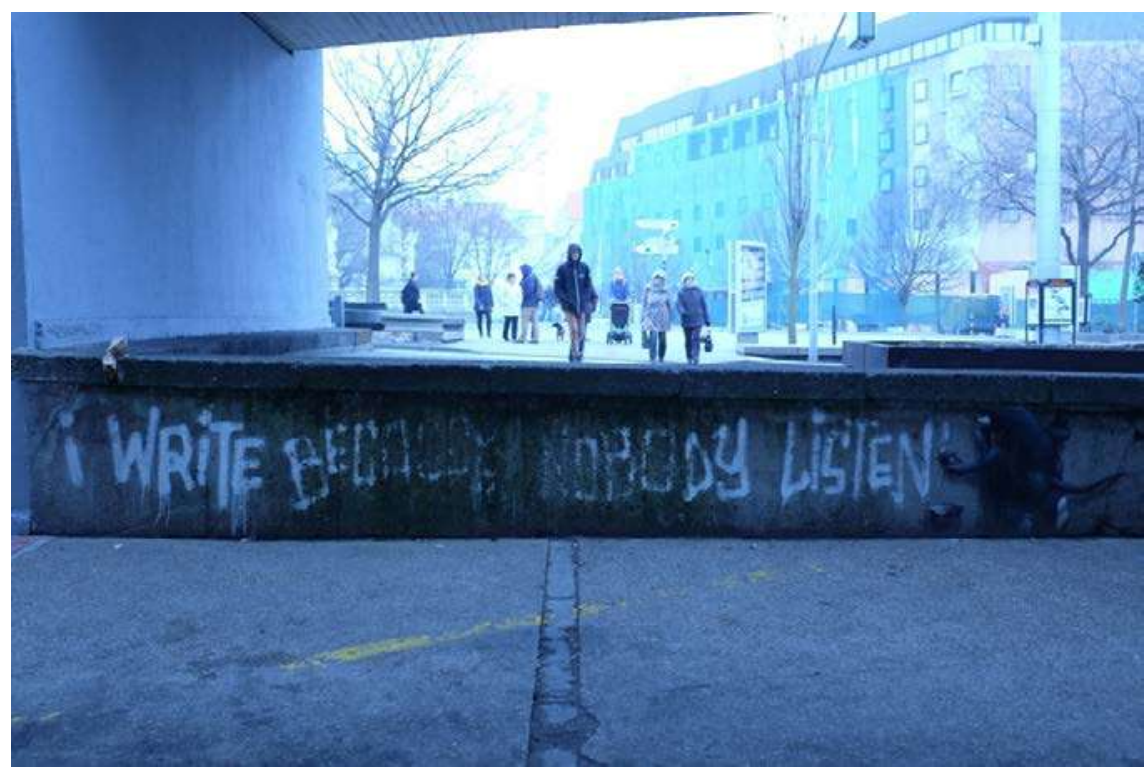

'I write because nobody listens', artist: Garth, Bratislava 2017; author's image

Yet, even in these alienated and disoriented moments signs of resistance are evident in public space, demanding their own share of visibility. 'I write because nobody listens' is a tag by the street artist Garth made at the central bus station in Bratislava. Other graffiti writers and street artists explain that for them this is a tactic to open us a public dialogue (Tsilimpounidi 2015), a form of a visual diary on the wall that informs passers-by about an alterna- 
tive history and narration that won't be broadcasted on the mainstream news (Bleeps 2014). If the question of space cannot be separated from the question of politics (Massey 2005), then it only follows that an engagement with urban interventions and street art has to take into consideration the politics behind these actions.

In other words, it is an expression of public consciousness that springs from lived experience, but which most often is seen as an illegal activity or vandalism. I argue that a close view on these kings of urban inscriptions in Bratislava (and elsewhere) is an opportunity to understand the political and social views of individuals and groups that would never otherwise be expressed in the mainstream culture or in the media. Furthermore, individual street artists take advantage of the urban environment to expose hidden stories to scrutiny and criticism and thereby enhance awareness in the wider community. Would anyone listen to Garth and engage in a meaningful dialogue? Can these acts of ephemeral reclamations of public space generate a more permanent and enduring politics of resistance? Of course, these are open-ended questions with no fixed and fatalistic answers, but being visible in public space, being able to be part of a city's aesthetics is already a small victory for whoever is out there and keeps an open ear for these messages.

As Nárcisz Fejes and Andrea Balogh explain in their edited volume Queer Visibility in Post-socialist Cultures, 'visibility is perhaps the only effective entry point for outsiders of the gay and lesbian community to break the vicious circle of heteronormativity and institutionalised homophobia in post-socialist Europe' $(2013,6)$. To put it differently, subversive queer visibility tactics in urban space hold the potential to destabilise hegemonic perceptions of space, gender, sexuality, and class. When I arrived in Bratislava I tried to find queer spaces in the city and my online search ended up in places with no address, - later on I realised these places did not exist anymore - facebook group profiles with no pictures, and fortunately a list of the two LGBTQI+ organisations. With effort and time, I met the people who then introduced me to the 'scene', but for the traveller or the passer-by Bratislava is a heteronormative space, very hostile to whatever is slightly different from what is perceived as the norm. This hostility explains the absence of queer performances and embodiments, yet this absence is coupled with extremely sexist and misogynistic attitudes, completely normalised and accepted in the public space of the city-centre. Of course, the one and only gay café is on the outskirts of the city-centre and to my enthusiasm has a big window to the street. If only those windows were not covered by (very stylish) blinds. It is in this context that I follow subversive signs, tags and street art pieces on the urban fabric with the hope that they would lead me to the urban fabric I want to discover.

\section{Queer coalitions: anti-conclusion}

Queering Bratislava? Why the need to queer a contested urban space? Perhaps it is my hubris to apply a Western concept in this urban space, am 
$\frac{0}{0}$ I going down the East-West slope? Queer, this 'English-language slur, turned defiantly against a social and discursive system abetting violence towards sexual nonconformist, reflects a culturally and historically specific dynamic of abuse and response in the US and UK' (Hall and Jagose 2013, xviii). Can a queer studies perspective acknowledge the strong Euro-American metropolitan bias and engage in a process of meaningful translation in a particular context? Or, perhaps as one of the reviewers ${ }^{5}$ of this paper correctly pointed out, can post-socialism be queered at all? And if so, is this version of 'queer' the correct way to 'queer' post-socialist contexts or does this strategy also imply a Western colonialism of various Eastern moments and politics of resistance?

There is continuous compromise and dialogue within any culture, or to use Homi Bhabha's words, by engaging in 'cultural translation' (1994) individuals deconstruct and reconstruct the way in which society is experienced and expressed. In his view cultures are dynamic products of translation between different systems of meaning. Bhabha describes this space of critical exchange as a 'third space' which holds the promise for an alternative society. For him, the collective site-building of such a third space would involve discursively and practically conceptualising an international culture which does not exoticise, nor uphold 'diversity', but prioritises hybridity. He calls for the recognition of 'the 'inter' - the cutting edge of translation and negotiation, the in-between space - that carries the burden of the meaning of culture. It makes it possible to begin envisaging national, anti-nationalist histories of the 'people'. And by exploring this Third Space we may elude the politics of polarity and emerge as others of our selves $(1994,38)$.

It is in this context that I discovered the foreignness of what I no longer am or no longer possess, as the opening quote by Italo Calvino indicates. Always a stranger, a foreigner, an outsider to the hegemonic values that guide daily urban life in Bratislava. Not because I was not from that city, but mainly because I was not conforming to the value system recognised in this city and elsewhere. My urbanity is not 'from' a particular geographical place, I have been an urban nomad for my entire life, but it derives from this 'inter', this in-between space of queer solidarities and bridge building. From that place I write this paper, not as an expert in Bratislava or post-socialist urbanisms. It is to that place that I would like to return, or perhaps just like John Raban (1973) and the Situationists reminded us: there is always another city underneath the hegemonic urban realities. Avenues of hope parallel the big streets, alleys of desire next to the offices of corporations, and the beach is beneath the cement.

These vignettes offer glimpses of this space and this is an unapologetically subjective view of the city and my experiences as a mestiza researcher in Bratislava. To quote Gloria Anzaldúa:

${ }^{5}$ I would like to thank the reviewers of this paper for their generous comments and feedback. 
As a mestiza I have no country, my homeland cast me out; yet all countries are mine because I am every woman's sister or potential lover. (As a lesbian I have no race, my own people disclaim me; but I am all races because there is the queer of me in all races.) I am cultureless because, as a feminist, I challenge the collective cultural/religious male- derived beliefs of Indo-Hispanics and Anglos; yet I am cultured because I am participating in the creation of yet another culture, a new story to explain the world and our participation in it, a new value system with images and symbols that connect us to each other and to the planet. Soy un amasamiento, I am an act of kneading, of uniting, and joining that not only has produced both a creature of darkness and a creature of light, but also a creature that questions the definitions of light and dark and gives them new meanings $(1987,102)$.

We live, work, and write in the difficult milieu of the European 'intersecting crises' (Carastathis, Spathopoulou and Tsilimpounidi 2018), a moment where the state reinforces national boundaries and suppresses radical politics, while at the same time xenophobic and racist coalitions win electoral votes and parliamentary representation all over Europe. In a similar way, social borders between 'insiders' and 'outsiders' are rigidly put around ethnicity, identity, race, and gender. Queer subjectivities are often one of the first targets of these conservative politics, while gender is once more considered a 'luxurious' category of analysis in the face of economic desperation, forced displacement, increasing death tolls in the EU/Turkey borders. To this might testify the absence of a Gender Studies department or centre in Slovakia. And perhaps, it is more imperatively and politically urgent now than ever to start the process of queering Bratislava, to add a critical and radical analysis of gender, sex and sexuality where it is missing or when present it is out of date. To start the process of 'making a certain set of ideas strange, to destabilize dominant understandings and underlying assumptions' (Daring et al. 2012, 14).

'Spaces can tell stories and unfold histories. Spaces can be interrupted, appropriated, and transformed through artistic [...] practice' (hooks 1990, 153). It is not a coincidence that most graffiti, political street art and urban intervention pieces can be found in borderlands - in spaces where boundaries blur and new forms of belonging emerge. The performance of making these artworks is a direct interaction between artist, social realities, and urban environment. In order to develop a visual response, artists become part of the place (if they were not already), they engage with the varied social tensions and struggles. Under these circumstances, this kind of political street $\operatorname{art}^{6}$ becomes a visual manifestation of local social attitudes and behaviors.

As such, political street art (despite the criticism that it is a trend that attracts unimaginative creations) clearly points out that a public wall is a place for creative expression, social communication and protest. It alters the city's image and in turn the identity of the people in it, taking active participation in shaping a contemporary 'wall culture' and mutely shouting out that the

${ }^{6}$ I refer here to political street art in order to differentiate this kind of work from tagging, commissioned street art pieces, murals, etc. 


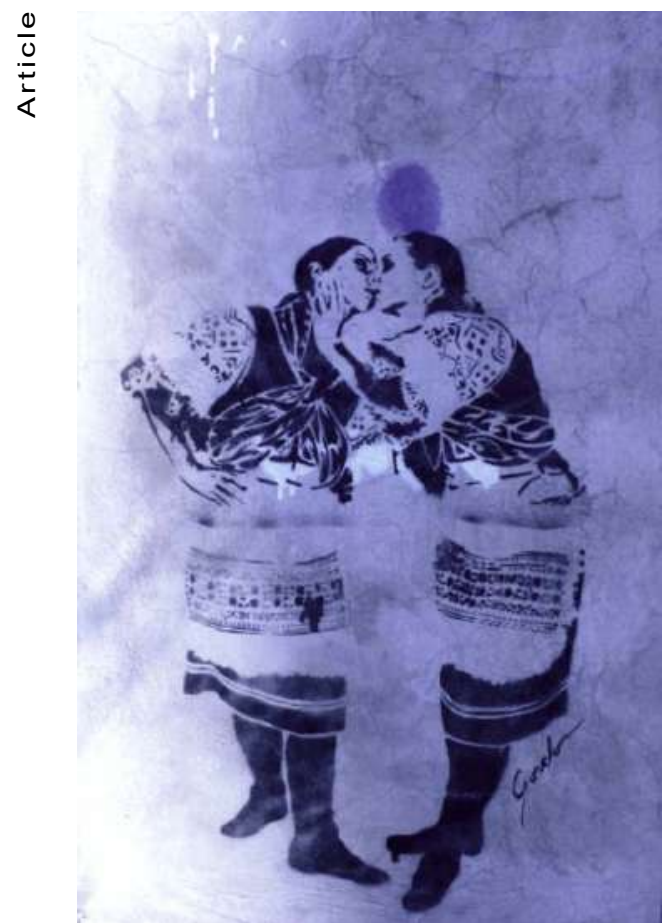

'The Kiss'; artist: Gordon;

Bratislava centre 2016; author's image

city is a living organism, bursting with energy and action in ways which cannot be bound by rules or restrictions. In this light, political street art is viewed as a barometer of freedom, as has been noted in studies of the juxtapositions between the freedom of the capitalist West and the totalitarian Eastern bloc which frequently made reference to the flowering of street art on the Western side of the Berlin Wall (Iverson 2010).

Political street art manages to create a mirror where we can recognise the features of our own concerns. What makes it remarkable is the personal and at the same time deeply collective voice that emerges from the pieces. Moreover, the voice transmits a common message, the words as living bridges between the street artists and the urban populace attempt to disrupt and disturb the hegemonic monopoly on truth (Tsilimpounidi 2013). This is precisely what Gordon's street art piece does; it points towards different possibilities, different desires and coalitions. And in these moments of rising nationalisms and fascisms we need a queer critique of the nation-state, the national symbols, and ethnic emblems.

Anzaldúa, Gloria. 1987. "La Consciencia de la Mestiza/Towards a New Consciousness." Borderlands / La Frontera: The New Mestiza, 77-91. San Francisco: Aunt Lute Books.

Benjamin, Walter. 1968. Illuminations: Essays and Reflections. New York: Schocken Books.

Berger, John. 1977. Ways of Seeing. London: Penguin Books.

Bhabha, Homi. 1994. The Location of Culture. London: Routledge.

Blazek, Matej and Pavel Šuška. 2017. "Towards Dialogic Post-Socialism: Relational Geographies of Europe and the Notion of Community in Urban Activism in Bratislava." Political Geography 61: 46-56.

Bleeps. 2014. "A Visual Diary in Public Display." Remapping Crisis: a Guide to Athens, ed. by M. Tsilimpounidi and A. Walsh, 221-225. London: Zero Books.

Calvino, Italo. 1972. Invisible Cities. San Diego: A Harvest Book.

Carstathis, Anna, Aila Spathopoulou, and Myrto Tsilimpounidi. 2018. “Crisis, What Crisis? Immigrants, Refugees, and Invisible Struggles." Refugee: Canada's Journal on Refugees 34 (1): 29-38. 
Christopoulou, Zacharoula. 2014. "Live your Myth in Greece: The Mythology of Crisis." Remapping Crisis: a Guide to Athens, ed. by M. Tsilimpounidi and A. Walsh, 267-281. Christopoulou London: Zero Books.

Daring, C.B., J. Rogue, Deric Shannon, and Abbey Volcano, eds. 2012. Queering Anarchism. Oakland: AK Press.

Douzinas, Costas. 2013. Philosophy and Resistance in the Crisis. Cambridge: Polity.

Fejes, Nárcisz and Andrea P. Balogh. 2013. Queer Visibility in Post-socialist Cultures. Bristol: Intellect.

Ferenčuhová, Slavomíra. 2011. “Urban Theory Beyond the 'East/West divide'? Cities and Urban Research in Postsocialist Europe." Urban Theory Beyond the West: A World of Cities, ed. by T. Edensor and M. Jayne, 65-74. London and New York: Routledge.

Jenks, Chris. 1995. "The Centrality of the Eye in Western Culture: An Introduction." Visual Culture, ed. by Chris Jenks, 1-25. London: Routledge.

Hall, Donald E. and Annamarie Jagose, eds. 2013. The Routledge Queer Studies Reader. London: Routledge.

Hirt, Sonia A. 2012. Iron Curtains: Gates, Suburbs and Privatization of Space in the Post-socialist City. Oxford: Wiley-Blackwell.

hooks, bell. 1990. "Choosing the Margins as a Space for Radical Openness." Yearning: Race, Gender and Cultural Politics, 145-154. Boston: South End Press.

Iverson, Kurt. 2010. "Social or Spatial Justice? Marcuse and Soja on the Right to the City." City 15 (2): 250-259.

Klein, Naomi. 2007. The Shock Doctrine: The Rise of Disaster Capitalism. New York: Picador Publishers.

Massey, Doreen. 2005. For Space. London: Sage.

Raban, John. 1973. Soft City. London: Collins Harvill.

Sedgwick, Kosofsky Eve. 2013. "Queer and Now." The Routledge Queer Studies Reader, ed. by D. E. Hall and A. Jagose, 3-18. London: Routledge.

Todorova, Maria and Zsuzsa Gille, eds. 2010. Post-communist Nostalgia. New York: Berghahn Books.

Tsilimpounidi, Myrto. 2017. Sociology of Crisis: Visualising Urban Austerity. London: Routledge.

Tsilimpounidi, Myrto. 2015. “'If These Walls Could Talk': Street Art and Urban Belonging in the Athens of Crisis." Laboratorium: Russian Review of Social Research, Special Issue on Street Art and Graffiti 7(2): 71-91.

Tsilimpounidi, Myrto. 2013. "'See the Writing on the Wall': Street Art and Urban Poetics." Inopinatum: The Unexpected Impertinence of Urban Creativity, ed. by L. Borriello and C. Ruggiero, 215-228. Rome: Arti Grafiche Boccia.

Zaroulia, Marilena and Phillip Hager. 2014. "Europhile or Eurosceptic? Gaps in the Narrative and Performances of Panic." Remapping Crisis: a Guide to Athens, ed. by M. Tsilimpounidi and A. Walsh, 226-248. London: Zero Books. 


\title{
Same-sex Parenting Practices in Hungary as an Assertion of Intimate Citizenship
}

\author{
Introduction
}

$\mathrm{T}$ he spring of 2016 brought high hopes and then bitter disappointment for a lesbian couple in the university town of Pécs, near the Croatian border. After one of the two women successfully qualified for adoption, she was chosen as the parent-to-be of a cute 3-year-old girl in state care. The child had been spending most of her weekends with them when an administrator at the local child welfare office decided that lesbians were not fit parents and terminated the adoption process. When the case came to light, a demonstration was organized in Budapest in front of the Ministry of Human Resources, with three lesbian mothers making speeches. This was the first time that in Hungary someone spoke publicly, showing her name and face, as a lesbian parent.

Hungarian law severely curtails the possibilities of same-sex couples to become parents, and rainbow families ${ }^{1}$ have been publicly almost invisible until very recently. This does not mean, however, that there were no attempts to subvert or circumvent state discourses and policies in order to assert the right to parenthood. In this paper I explore such discourses and practices in the Hungarian LGBTQ community through the lens of intimate citizenship. I argue that the concept of intimate citizenship needs to be expanded to encompass the variety of ways LGBTQ people attempt to become parents and/or justify their chosen family forms.

\footnotetext{
${ }^{1}$ Rainbow families are defined as "families with children where parents are lesbian, gay, non-heterosexual or transgender people" (Kuosmanen \& Jämsä 2007, 13, my translation). I will use this term when referring to families composed of same-sex couples with children. Other terms are problematic (Stacey 1996, 107), especially as most of them automatically define the members of the same-sex couple as gay or lesbian, even though this might conflict with their self-definition.
} 
The paper is based on ethnographic fieldwork that I conducted in the Hungarian LGBTQ community² from 2007 to 2013 . I interviewed 68 people who live or have lived in same-sex relationships; 21 of these had children. I conducted participant observation at various workshops, roundtable discussions and other events focusing on family and parenthood, and conducted informal conversations with members of the LGBTQ community. I also examined written sources: an interview volume with lesbian and gay parents published by Inter Alia Association (Sándor 2010), various forum threads on the websites labrisz.hu and pride.hu, and blogs of self-identified gay, lesbian and genderqueer bloggers. Due to the sensitivity of the topic, especially in the Hungarian homophobic context, I protect the anonymity of my respondents by assigning pseudonyms for them, omitting or changing identification data and, in the case of online sources, not publishing the exact online location (which, in the case of pride.hu, is no longer available anyway).

In this paper, I will first discuss the concept of intimate citizenship, and the benefits of applying it to same-sex parenting. I will then outline the legal framework in Hungary and what forms of same-sex parenthood it permits or hinders. Then I will bring examples to how members of the LGBTQ community try to have children in spite of these restrictions, or to justify their ability to parent. Examined through the lens of intimate citizenship, some of these examples can open up new possibilities in theorizing the connection of the individual and the state.

While the sexual/intimate citizenship of LGBTQ people is frequently discussed in American scholarship (e.g. Bell \& Binnie 2000; Canaday 2009; Cossman 2007), these works rarely direct attention to parenthood. One possible reason is that in Anglo-Saxon countries same-sex parenting is less problematic legally and in terms of public attitudes than same-sex marriage, whereas in continental Europe this is the other way round (Takács \& Szalma $2013,2-3)$. It should come as no surprise that much of the not-too-large scholarship examining parenting as a citizenship issue comes from this region (e.g. Ryan-Flood 2009). With this article I hope to add to this thread of citizenship literature and call attention to a hitherto undertheorized field of intimate citizenship.

\section{The intimate citizenship framework}

The notion of intimate citizenship was introduced by Ken Plummer in his work with the same title (Plummer 2003). Under this term he means the possibility of various decisions, access and choices related to the body and intimacy (Plummer 2003, 14). Based but also expanding on this, Roseneil

\footnotetext{
2 The acronym LGBTQ stands for 'Lesbian, Gay, Bisexual, Transgender and Queer'. It is common to also add the letters I (for intersex) and A (for asexual), but during my fieldwork these two groups were barely visible in Hungary, so I felt including their letter would be an empty gesture. While I did not specifically research transgender subjects, they did participate in the workshops and online discussions that I studied.
} 
defines intimate citizenship as "the freedom and ability to construct and live selfhood and a wide range of close relationships - sexual/love relationships, friendships, parental and kin relations - safely, securely and according to personal choice, in their dynamic and changing forms, with respect, recognition and support from state and civil society" (Roseneil \& Stoilova 2011 , 168). We can see that, in contrast to the more often used but also more controversial notion of sexual citizenship (Bell \& Binnie 2000; Phelan 2001; Weeks 1999), intimate citizenship is a broader concept, including also non-sexual intimate relations such as those between parents and children. Also, Roseneil's definition does not limit the scope of this concept to the relationship between the individual and the state, but also includes civil society, that is, other communities of belonging. As we will see, in the struggle to have their parenting rights acknowledged, Hungarian LGBTQ people do not always target the state, but sometimes try to change attitudes in their immediate environment.

Studies on the intimate or sexual citizenship of LGBTQ people often limit themselves to discussing the constraints this group faces within heteronormative mainstream society (Bell and Binnie 2000; Cossman 2007). Other authors recognize the agency of LGBTQ people in claiming recognition for their relationship forms but vary in what they consider the methods for this. Studies on LGBTQ movements tend to focus on activist strategies to lobby for recognition, sometimes explicitly using citizenship rhetoric (Nicolae 2009) or emphasizing their belonging to the nation (Renkin 2009). The agency to argue for social inclusion is not limited to groups or movements, however; much can be done on the individual level. Tereskinas (2008), for instance, argues that in a heteronormative context public coming out can qualify as an assertion of intimate citizenship. Canaday (2009) discusses the way non-heterosexual immigrants to the US found loopholes in the system at a time when state policies would have turned them away. This is similar to de Certeau's notion of tactics, ways to work against the system from inside with rhetoric and everyday practices (de Certeau 1988, 23-24). Some of these practices may be illegal or unrecognized by the law (de Certeau 1988, 25), like the same-sex wedding ceremonies Lewin studied in the US when none of the states officially recognized marriage equality (Lewin 1998).

These ways of claiming intimate citizenship - coming out, alternative discourses, activism, finding loopholes in the system orlegally unacknowledged practices - are observable in the Hungarian LGBTQ community with respect to parenting rights. There are others, too, which are rarely seen as assertions of intimate citizenship, such as language use or 'acting out'. Some of these practices are certainly controversial, but they are useful for highlighting some theoretical difficulties concerning the notion of intimate citizenship. We must also consider that in certain legal and/or social environments not all these solutions are feasible or even possible. Hungarian law is varied with regard to the different forms of rainbow families, so fighting for intimate citizenship requires flexibility in, and often a combination of, the techniques discussed above. 


\section{Rainbow families in Hungary: legal and societal context}

In Hungary the main legal disadvantage same-sex couples face in comparison to heterosexuals is access to parenthood. Individual gays and lesbians can adopt, but not a same-sex couple together ${ }^{3}$. Similarly, single women (regardless of sexual orientation) have access to assisted reproduction techniques (ART), but they have to sign a paper declaring they are single ${ }^{4}$; as cohabitation (whether registered or not) is a different family status, a lesbian living with her partner would commit forgery by signing this document. Hiring a surrogate is punishable by imprisonment of up to 3 years, and so is the practice - popular among lesbians in some countries (Ryan-Flood 2009, 43-76) - of conducting home insemination with a known donor's sperm (in Hungarian law it classifies as "forbidden use of the human body"). As secondparent adoption is also denied to same-sex couples, the biological or adoptive parent's partner cannot gain formal parental status; at best s/he qualifies as a stepparent, which grants certain rights but not equal parenthood. The law explicitly bans same-sex couples from becoming foster parents.

In spite of such difficulties, there is a considerable number of rainbow families in Hungary: in an online LGBQ survey conducted in 2016-2017 $(n=1249), 13 \%$ of respondents were parents; though the majority of children came from heterosexual relationships, 36\% of these families were planned rainbow families (Háttér Társaság 2017, 7). This need not come as a surprise, if we consider that most of the laws mentioned above do not spell out "LGBTQ", they only refer to same-sex couples; individual LGBTQ people qualify for artificial insemination or adoption if they do not have a same-sex partner (or deny having one). The state is apparently less interested in the sexual orientation of single parents than in making sure there are no families with two parents of the same gender so as to preserve the heteronormative model of the family. This results in the "anomaly" that there is a considerable number of families in the country with same-gender parents, but these are not visible in any formal way. No wonder then that one of the main goals of activist organizations working in this field is second-parent adoption.

\section{Activism}

The activities of LGBTQ organizations are perhaps the most widely researched segment of the LGBTQ community. It is understandable: these organizations are easily accessible for research, and scholars not wishing to

\footnotetext{
${ }^{3}$ In the fall of 2020, the Hungarian Parliament passed a law which bans adoption by single persons, except with a special ministry permit. This practically makes it impossible for non-heterosexuals to adopt a child. A protest campaign, under the hashtag \#acsaládazcsalád (\#familyisfamily) has been launched by experts and rainbow families, which was also the first instance adoptive gay male parents have come out in public.
}

${ }^{4}$ Apparently, this rule is not always taken seriously, as some lesbian mothers and mothersto-be I spoke to do not recall ever signing such a document. 
do interviews or participant observation can still get results by looking at the publicly available documents of such groups. Especially groups lobbying for legal change are highly visible in the public sphere, and some scholars put them in the focus of exploring claims for intimate citizenship (Nicolae 2009; Renkin 2009). At the same time, some queer authors criticize these organizations for seeking assimilationist goals and equating legal gains with full citizenship (Bell \& Binnie 2000, 49-50). Such criticism fails to see that many LGBTQ organizations (also ones doing lobbying work) pursue other goals as well like educational programs, consciousness-raising or practical and psychological support within the community (Bruce 2016, 6-7). ${ }^{5}$

The three organizations working for rainbow families in Hungary are a good illustration for this claim. Háttér Society, an NGO with a wide range of programs from community building to mental health, operates a Legal Aid service that also lobbies for second-parent adoption in rainbow families and access to ART for lesbians; but from time to time they organize workshops for members of the LGBTQ community to raise awareness to their rights. Inter Alia Foundation (in operation from 2010 to 2012), besides lobbying for second-parent adoption, published an interview volume with parenting same-sex couples (Sándor 2010), which gave visibility to this extremely closeted group (see next section). The couples describe the way they managed to get a child, which in many cases involved breaking the law. Along the same lines, the Foundation for Rainbow Families used to ${ }^{6}$ organize workshops that gave ideas to participants about how to become parents and manage the challenges of same-sex parenthood. Thus, even activist organizations use several strategies to promote the intimate citizenship of their contingency, even if for casual observers their lobbying activity is the most visible.

Nor are references to the law limited to activists. In fact, the antidiscrimination law, which bans various forms of discrimination on the basis of (among others) sexual orientation and gender identity, can be a powerful tool to claim equal citizenship symbolically and in practical situations. Tekla, a rural working-class mother, fell out with her ex-husband's family because they disapproved of her lesbian relationship and sent the Child Protection Agency to take her kids away, claiming she was leading an 'immoral life'. Fortunately, Tekla had been involved in the local LGBTQ group and had attended a legal awareness training, so she knew that custody cannot be withdrawn on the basis of one's sexual orientation alone. She contacted a lawyer and Háttér Legal Aid, and within two weeks she got her children back (Tekla, interview). Her example shows that claiming equal citizenship with

\footnotetext{
${ }^{5}$ A recent Hungarian example for this partial view is Mészáros (2018), who looks at the word cloud on Háttér Society's website, and as he associates 9 out of the 30 expressions with legal rights, reaches the conclusion that this is the organization's main profile (Mészáros 2018,222 ) - instead of clicking on the general description of the organization, from which he could find out that only one of its seven (?) programs focuses on legal equality.

${ }^{6}$ Since two of its three founders moved abroad a couple of years ago, the activities of the Foundation have been mostly limited to their website.
} 
reference to laws is not limited to organizations but indeed forms part of the repertoire of members of the LGBTQ community in Hungary.

\section{Visibility}

Early gay and lesbian activism in the 1970s promoted coming out as a central tool for achieving equality (Weeks 1985, 197). The power of disclosing one's sexual orientation has been discussed by various authors on the level of individual psychology (Sandford 2000, 23-24), transforming discourses (Plummer 1997, 133-148) and as a prerequisite of collective action (Plummer 1997, 145). Within the postsocialist context, Tereskinas argues that coming out disrupts the invisibility of same-sex sexualities in the public sphere (Tereskinas 2008, 93), something Kuhar calls 'heteronormative panopticon' (Kuhar 2011, 151-152). Others, however, argue against the uncritical adoption of Western notions of visibility in a culturally different region. Stella's Russian respondents see empowerment not in coming out, but in being able to manage their visibility themselves; they experience the closet not as a constraint but as a space where they can get privacy (Stella 2015, 108). The possible dangers that coming out creates do not remain on the individual level; Edenborg demonstrates how in Russia the increased visibility of LGBTQ people has made them suitable scapegoats for the authoritarian state (Edenborg 2017, 76-99).

Hungarian same-sex couples raising children are in a deadlock with respect to visibility. On the one hand, they cannot claim rights or recognition in a context where their very existence is unacknowledged. Though Hungarian media sometimes reports about Western research findings on the ability of gays and lesbians to parent, apart from a few tabloid articles about (invariably female-headed) reconstructed rainbow families, the general public has no awareness that same-sex couples are actually raising children (some of them in planned rainbow families) in contemporary Hungary (Borgos 2011, 89) ${ }^{7}$. If legislators are not aware of the existence of a group, they will not consider granting them rights; similarly, the only way both members of a couple can be acknowledged as their child's parents is if they disclose their relationship to their environment. On the other hand, this is exactly what parents in rainbow families are afraid to do, fearing this would lead to repercussions for their child in various contexts, such as at school (Béres-Deák 2012, 500-503). This is why publications like the Inter Alia interview volume (Sándor 2010) are so important: as the interviews are anonymized, they do not expose rainbow families to backlash, but at the same time raise awareness to their existence and difficulties.

At the same time there are many same-sex parents who come out in their broader environment to claim equality, like Tekla did when she went with her lawyers to the Child Protection Agency. The lesbian mothers at the 2016

${ }^{7}$ On the invisibility of rainbow families in education, see Béres-Deák (2012). 
protest spoke about their experiences in order to pinpoint the difficulties they face in a culture that does not acknowledge same-sex relationships as family; for instance, the last speaker, a social parent, ${ }^{8}$ complained that neither the law nor various institutions recognize her as an equal parent to the child her partner had given birth to (author's field notes). This demonstration potentially signals a new stage in the activism for rainbow families, using the disclosure of personal experience as a tool for creating empathy and for claiming intimate citizenship (Plummer 1997).

\section{Loopholes/ tactics/lies}

As discussed above, Hungarian law severely curtails the rights of lesbians to assisted reproduction techniques. Still, this is the preferred way for women in the LGBTQ community to have children, potentially because there are various opportunities to get around legal barriers. For one thing, the law does not discriminate against non-heterosexual single women; therefore many lesbian couples do not register their partnership, which is then not traceable in legal documents and this makes them potentially eligible for ART. ${ }^{9}$ Even at the time when ART was only accessible to (married or unmarried) heterosexual couples, lesbians found a way to benefit from this service, as Judit's account proves:

When I first went, you couldn't get it as a single woman. And we had no idea it'd change soon, so then there was a pretend father. We said he was the father but his sperm wasn't good so we wanted ART. [...] And when I saw in the newspaper that the law had been adopted and now single women can get it too, I told the doctor there was no father anymore, we'd broken up, but I still wanted the child, even as a single woman (Judit, interview).

This story is an illustration of how flexibly members of the LGBTQ community adapt to the legal framework and its changes. The following story relates such an adaptation with regard to another issue: the fact that (except for anonymous donor insemination) the child's father must be named in official documents. This creates difficulties for women like Zsófi, who did not wish to involve her (known) sperm donor in the child's life or give him any paternal rights, and therefore lied about his marital status.

I couldn't tell the truth. I could have pretended we'd broken up [with the father], but they'd still have pressured me to tell the father's name and make him pay child support. And I didn't want that. So I had to tell a story that would make them let him be and accept the situation as it is. So I had to say he was married (Zsófi, interview).

In this case it is not laws but institutional policies, based on a notion of a direct correspondence of biology and kinship, that caused difficulties

\footnotetext{
${ }^{8}$ I use the term 'social parent' to denote the legal (i.e., biological or adoptive) parent's samesex partner.

${ }^{9}$ As mentioned above, women who simply co-habit with their partner are not officially single either, but their relationship status is harder to prove or disprove.
} 
for Zsófi. The path she chose is controversial in several respects. On the one hand, she felt she was treated with contempt: "I'm a dirty slut because I've lain with a married man" (Zsófi, interview). As Kipnis argues, adultery is also considered a form of 'bad citizenship' (Kipnis 2000,14), so in this sense Zsófi's claim for recognition was unsuccessful, though not on the grounds of her sexual orientation. Also, she did not come out as a lesbian mother; given that her chosen model (two mothers, a child and an uninvolved donor) is not recognized in Hungarian law or mainstream discourses, the best she could do was ensure that the donor is not considered part of her family. Her story is an example of the trade-ins rainbow families are forced to make when legal recognition can only be realized at the cost of invisibility or social marginalization.

In the stories above, women hid their sexual orientation in order to gain access to parenting in a given family form; their sexual citizenship tactics targeted the law and institutional policies. For others, recognition in the public sphere may require other types of lies and silences. Péter and Jocó, a rural gay couple, do not tell strangers which of them is the biological father of their children. "They ask whose child it is. And then we say it belongs to both of $u s^{\prime \prime}$ (Péter, workshop discussion). They are keenly aware that the recognition of kinship in our culture is predicated on biology (Schneider 1968, 23), and they wish to be treated as equal parents to their children. They are also making a public statement, introducing a new conception of family into public discourses; thus, their tactic works on the individual and general level, and on the level of practices as well as discourses. While many LGBTQ people use their personal examples to effect change in their treatment, they often do it with the explicit aim of influencing public discourses as well.

\section{Alternative discourses}

Several authors see rainbow families as a subversion of heteronormative conceptions of kinship (Hayden 2004; Sullivan 2004) and as "the frontrunners of a new form of $21^{\text {st }}$-century family" (Du Chesne and Bradley 2007, 25). For others, parenting is an assimilationist goal that even in its more radical forms reinforces heteronormativity (Bell \& Binnie 2000, 137-138). Lewin, however, warns that a dichotomized view of accommodation and subversion is problematic, as the two are often interconnected (Lewin 1998, 242). A rainbow family is by definition subversive in a context like Hungary, where the law and mainstream discourses see heterosexual relationships as the foundation of kinship. At the same time, LGBTQ people do adhere to certain dominant notions of family while problematizing or rejecting others.

As we have seen, lesbians like Judit and Zsófi do not find it important to involve the child's genitor in their family, whether they used a known or anonymous donor for insemination. This decision runs contrary to the idea that children need parents of both sexes for healthy development, something that is widely propagated in Hungarian popular and scientific discourses (Lux 
2008, 166-167). On the Inter Alia blog, Bea Sándor, founder of the association, counters this notion by exposing its underlying sexism: „[w] hat do you mean by 'male role model'? [...] Not paid work or appearing in public space, surely? Because these are things women can now do too" (Sándor 2010). Far from being assimilationist, this argument attacks the foundations of the heteronormative family model and seeks to substitute it with one that sees gender roles as cultural constructs, supporting Sullivan's claim that lesbian-headed families can be agents of social change towards the deconstruction of gender (Sullivan 2004, 11). Inter Alia Foundation also lobbied strongly for second-parent adoption, and its interview volume (Sándor 2010) propagates two-parent lesbian families without the involvement of any adult men. Besides the gender aspect, this model also disrupts what Schneider calls one of the basic tenets of Western kinship, 'blood is thicker than water' (Schneider 1968, 23), as it claims that the genitor's biogenetic connection does not automatically makes him kin.

While many lesbians in Hungary question the gender-based notion of parenting, others and most gay men I spoke to challenge the mainstream image of the family from another direction: their preferred family model is a gay couple co-parenting with a single woman or a lesbian couple. At a workshop organized by the Foundation for Rainbow Families, a group of participants collected the advantages of this family model: their list included more love, more grandparents who can be mobilized when needed, more role models and more financial resources (author's field notes). These are all values that are often voiced in mainstream Hungarian discourses as foundational for the family. By promoting a three- or four-parent family model, LGBTQ people make use of dominant notions of the family to argue that same-sex parenting in fact serves the interest of the child better than the two-parent heterosexual nuclear family.

Subversive meanings are most successfully communicated if they rely on tropes well-known from dominant narratives (Edenborg 2017, 176-179). Notions of the ideal family within the Hungarian LGBTQ community reinforce some of the values circulating in mainstream discourses but use them to demonstrate the value of rainbow families. Another tactic to assert this value is through the use of language.

\section{Language}

In studies of kinship, the vocabulary used for describing family members has been central for over a century. Early anthropologists debated over the direct correspondence between kinship terms and the corresponding feelings or duties (Parkin 2004). This question resurfaced with postmodernism when, relying on the performativity theory of J. L. Austin (Austin 1962), Marshall Sahlins argued that the use of kin terms performatively creates kinship (Sahlins 2013). The symbolic value of the words used especially for parents is well illustrated by the confusion many people feel at the idea of certain 
assisted reproduction techniques, whereby more than one person could claim the term 'mother' (Edwards 2000).

The idea that there may be two mothers in a lesbian-headed family challenges both the equation of motherhood with giving birth (Hayden 2004,381 ) and the idea that only biogenetically related people should count as parents. Though some female couples reserve the term 'mother' for the woman who gave birth (Polášková 2007, 210-212), others express through their vocabulary that they do not differentiate between biological and social motherhood. Zsófi, whom we met a few pages earlier, separated from her partner a couple of years after our interview and then found a new girlfriend. When we ran into each other at an event, I expressed my joy that her little daughter has two mothers again (testing this way whether her new partner counts as a mother). “Two? She has four, even!”, Zsófi answered, including her ex-partner and her (the ex's) new girlfriend among the child's mothers (author's field notes). Like the workshop participants in the previous section, she is open to extending parenthood to include more than two people, and like Péter and Jocó, considers these parents all equals, worthy of the same recognition.

Due to the performative nature of kin terms (Sahlins 2013), their use can be a path to the recognition of a rainbow family by its environment. Rafael and Gusztáv co-parent two children with a lesbian couple: Rafael is the little girl's, Gusztáv is the little boy's biological father. Biogenetic connection is extremely important for Rafael (indeed this was the reason he opted for coparenting), and he consequentially differentiates between "my daughter" and "his [Gusztáv's] son", correcting the little boy every time he calls him 'daddy' (author's field notes). This approach seemed to backfire with Rafael's father, however, who initially opposed homosexuality and same-sex parenting, and did not like it when his son brought the children to his home, especially the boy, for whom Rafael is the social parent. His attitude improved when the little boy started calling him 'grandpa' (and, perhaps strategically, this time Rafael did not intervene). This story does not only illustrate the power of kinship terms, but also the agency members of rainbow families have in claiming recognition for their family form - already at the age of two.

\section{Illegal practices}

Whereas the practices discussed above are recognized in at least some literature as forms of claiming recognition, to my knowledge no author connects illegal practices with claiming intimate citizenship. After all, citizenship is supposed to mean belonging to a state, so in principle breaking the state's laws would work against it. However, this approach does not consider that membership in a community does not (only) depend on abiding its laws but on living up to its norms. In pronatalist Hungary, childlessness especially among women - is strongly stigmatized (Takács \& Szalma 2014,129 ), proving that in nationalist contexts motherhood is the central 
$\frac{0}{0}$ mechanism for incorporating women in the political order (Pateman 1992, 19). As we have seen, however, the law tries to make sure that women living in lesbian relationships do not have access to reproduction. Thus, in principle same-sex loving women have no access to full citizenship in Hungary.

Recognizing this double bind, many members of the Hungarian LGBTQ community decide that breaking the law in order to achieve parenthood is not a condemnable act. "Those who are not granted the basic human rights (in this case, to give birth to a child and raise her or him in a loving environment with our partner or alone) will look for the 'back door'”, Princess explains on the pride.hu forum. Besides theoretical support, members of the community also help each other with ideas how to circumvent legal barriers. It is common advice, for instance, that women should use home insemination with the sperm of a man they trust, as in this case it is almost impossible to prove they have broken the law. At the parenting workshop focusing on surrogacy, it was mentioned that in order to circumvent the law, some Hungarians used Ukrainian surrogates to make the offence harder to trace (author's fieldnotes).

The latter case is interesting not only because it acknowledges the existence of illegal practices but also because it contests the ethnicity-based definition of the nation dominant in Central and Eastern Europe (Smith 1991, 11). With the example of Israel (another country with strong ethnic nationalism) Hovav demonstrates that such definitions also affect surrogacy, with a preference for surrogates who belong to the 'nation' (Hovav 2011, 1317). The message of the workshop participants is that, in order to gain full symbolic belonging to the nation as parents, gay men must give up, at least partly, the genetically-based conceptions of kinship and nation; a foreign element is necessary to make them full citizens in Hungary. Others emphasize the foreign element even more by saying that they must leave the country in order to gain full equality with heterosexual parents.

\section{Acting out}

$B$ : That's why we want to move to Denmark as soon as possible, because there's marriage and we know several people who are already citizens there and [inaudible].

$K$ : That's definitely my aim, so looking ahead about 10 years, 10 years from now we'd like to be managing the adoption papers already. (...)

$B D R$ : And if in Hungary you had the same possibilities, like you could adopt a child here, would you still want to leave?

$K$ : Probably not.

$B D R$ : So this is in fact what motivates you.

$K$ : That we should be able to live as a family (Bálint and Krisztián, interview).

In the Hungarian LGBTQ community, moving to the West has been a popular strategy from the 1980s onward to escape homophobic climate: in an interview-based research with gay men in 1983, 60\% wanted to leave the country (Takács 2008, 182) and this tendency increased with the opening up of Hungary's borders towards the EU. Bálint and Krisztián are part of a 
more recent trend, whereby same-sex couples leave the country in order to become parents. In the case of adoption this means also giving up their Hungarian citizenship. ${ }^{10}$ Thus formal political citizenship and full intimate citizenship may be mutually exclusive, an issue that citizenship literature has hardly tackled to date. At the same time, when celebrities choose this path like Kristóf Steiner, a popular TV host and author of vegan cookbooks, who moved to Israel with his partner to escape homophobia in Hungary and adopt a child - the general public becomes more aware of the barriers to inclusion same-sex couples face in contemporary Hungary, so the 'acting out' may in fact influence public discourses.

Besides the legal difficulties of becoming parents, many same-sex couples are worried about the homophobic cultural climate in Hungary, which they are afraid may cause difficulties for children growing up in rainbow families. At the same time, plans to move abroad does not necessarily mean lack of attachment to one's home country. Benő, a young gay man who is in the planning phase of parenthood, voices the dilemmas coming from a sense of belonging and distancing at the same time.

\begin{abstract}
$B$ : I don't necessarily plan to raise my children in Hungary.
BDR: You mean [you want to raise them] abroad?

$B$ : Uh-huh. I'm not sure that it'd be good for a child to grow up in present-day Hungarian reality.

$B D R$ : Because his/her ${ }^{11}$ parents are gay, or for other reasons?

$B$ : Er, primarily because his/her parents are gay. But of course, there are other factors, I don't know, I don't really like living in Hungary right now. And that's why. What's strange - not strange but controversial is that I'd really like my child or my children to spend their childhood and part of it in Hungary. So to pass on to them some of this cultural heritage. To learn the language. So it wouldn't only depend on me, or me and my partner that the kids speak good Hungarian, but so they'd spend some time in this environment. So to form in them some of this identity too (Benő, interview).
\end{abstract}

Benő feels an attachment to his home country, which he hopes to pass on to his child, but at the same time, wishes to protect her/him from Hungarian homophobia, a dilemma many members of the Hungarian LGBTQ community face. Imre $(2008,269)$ argues that whereas Hungarian lesbians distance themselves from state-propagated nationalism, they nevertheless appropriate elements of national culture. Though in some cases such moves may be part of a conscious strategy to claim inclusion in the nation (Renkin 2009), Benő feels genuinely attached to his home environment and language. His painful monologue illustrates that the often-celebrated queer internationalism (Altman 2001) may be a necessity rather than free choice for those who are excluded from citizenship in their home country.

\footnotetext{
${ }^{10}$ Not necessarily in the case of ART for lesbians, as in many countries this is accessible for foreign citizens as well; however, the Hungarian state still would not grant full rights to the social parent.

${ }^{11}$ Hungarian does not have grammatical gender, so I translated the third person singular personal pronoun (ó) as s/he.
} 


\section{Conclusion}

Though some authors from Central and Eastern Europe have embraced the concept (see Kuhar 2011; Rédai 2015; Tereskinas 2008), intimate/sexual citizenship has remained largely connected with Western Europe and North America. This has affected the way it is theorized: sexual/intimate citizenship scholars focus largely on activism and public discourses (Bell \& Binnie 2000; Phelan 2001) or inclusion through consumption (Evans 1993), while the everyday practices and discourses of average LGBTQ people largely remain unseen (except e.g., Lewin 1998 or Ryan-Flood 2009). The intimate/ sexual citizenship perspective is usually applied to issues figuring strongly in (North American) activism like marriage equality (Bell \& Binnie 2000; Cossman 2007), but not to same-sex parenting, which is considered less of a problem in that context (though works studying the experiences of gay and lesbian parents in their environment like Lewin (2009) or Mallon (2004) suggest otherwise). Rainbow families figure in scholarship in terms of being similar to or different from heterosexual ones (for a summary of such studies see Biblarz \& Stacey 2010) or as revolutionaries transforming the concept of family (Du Chesne \&Bradley 2007; Sullivan 2004); their actual experiences of inclusion and exclusion are not theorized in the framework of intimate citizenship (with again Ryan-Flood 2009 as a counterexample - tellingly, from Europe). I believe it is time to extend intimate citizenship analysis to rainbow families, as this would enrich the scope and content of this research field. I also believe that examining contexts other than Western through this lens would add valuable insights into processes of inclusion and exclusion. Based on the examples above, I will list a few of these here.

First of all, it is important to consider that not only the goals but also the strategies of LGBTQ people fighting for inclusion depend strongly on the social context. Some scholars from this region do question the usefulness of pride marches, for example, in a context where most people are closeted and their main concerns are not human rights but being accepted in their environment (Bilić 2016; Butterfield 2016), but they operate with a narrow interpretation of human rights, which ostensibly does not contain social rights and social inclusion. I do believe that a struggle for visibility and social inclusion does fit the human rights framework, and we have seen above that these are important for Hungarian present and future LGBTQ parents. The tactics they use to achieve these aims, however, must be adapted to the social environment. In a country where public homophobia prevails, especially in education (Béres-Deák 2012), same-sex parents find it risky to come out in public lest their children should suffer as a consequence; anonymous interviews like the ones in the Inter Alia volume may solve this problem. Also, within a state that grants LGBTQ rights only rarely and grudgingly, most people do not believe in the short-term success of lobbying. Aspiring LGBTQ parents take matters in their own hands, and even activist organizations are willing to assist them. This emphasizes the agency individual community members have in claiming 
intimate citizenship, even if it means circumventing the law. As we have seen, this is not necessarily considered problematic; the notion that unnecessarily constraining laws serving those in power and not the interest of the people can be broken is present in Hungarian public discourses in general (Kapitány \& Kapitány 2007, 230-231) and in the LGBTQ community in particular.

This leads us to my second point: a need to expand the notion of intimate citizenship. Contrary to a narrow interpretation of laws facilitating the inclusion or exclusion of LGBTQ people, a community-oriented view of intimate citizenship also considers discourses, everyday practices and inclusion in civil society, something Manalansan calls cultural citizenship (Manalansan 2003, 16). This broader definition of intimate citizenship, in turn, allows us to examine from this perspective strategies which hitherto have been inadequately theorized in scholarship: language use, finding loopholes in the legal system, illegal or semi-legal practices or leaving the country. The last ones are especially interesting because they highlight the way different forms of citizenship may be mutually exclusive. While a good citizen is supposed to respect the law, s/he (especially she) is also expected to produce offspring, but in a same-sex relationship s/he may be unable to do this without breaking the law. For gay couples who move abroad in order to jointly adopt a child, formal Hungarian citizenship excludes the possibility of being regarded as family, that is, their intimate citizenship. Just like Robertson's claim that suicide (at least in the Japanese context) may be a way of claiming citizenship (Robertson 2007, 224), this form of 'acting out' also exposes the controversies of inclusion within the society that the samesex couple is escaping, especially if the case gets high publicity. At the same time, the stories of gay men forced to leave the country in order to become fathers adds a new perspective to theories of queer transnationalism and globalization.

Hungarian rainbow families have been invisible in both the law and public discourses until recently. They do not passively accept this status, however, but use a wide range of strategies to claim recognition for their family form. Examining these can broaden our understanding of social inclusion and intimate citizenship.

Altman, Denis. 2001. Global Sex. Chicago and London: University of Chicago Press.

Austin, John L. 1962. How to Do Things with Words: The William James Lectures delivered at Harvard University in 1955, ed. by J. O. Urmson, and M. Sbisà. Oxford: Clarendon Press.

Bell, David, and Binnie, Jon. 2000. The Sexual Citizen. Queer Politics and Beyond. Cambridge: Polity Press.

Béres-Deák, Rita. 2012. "Szivárványcsaládok a magyar oktatásban". Új kutatások a neveléstudományokban. A munka és a nevelés világa a tudományban, ed. by K. Tamás and I. Perjés, 491-508. Budapest: MTA Pedagógiai Tudományos Bizottság - ELTE Eötvös Kiadó.

Biblarz, Timothy J., and Stacey, Judith. 2010. "How does the Gender of Parents Matter?". Journal of Marriage and Family 72: 3-22. 
Bilić, Bojan. 2016. "Europe Gays? Europeanisation and Pride Parades in Serbia". LGBT Activism and Europeanisation in the Post-Yugoslav Space. On the Rainbow Way to Europe, ed. by B. Bilić, 117-154. London: Palgrave Macmillan.

Borgos, Anna. 2011. “Diskurzusok a kétanyás családokról: kutatások és közbeszédek”. Homofóbia Magyarországon, ed. by J. Takács, 80-93. Budapest: L’Harmattan.

Bruce, Katherine. 2016. Pride Parades. How a Parade Changed the World. New York: New York University Press.

Butterfield, Nicole. 2016. "Discontents of Professionalisation: Sexual Politics and Activism in Croatia in the Context of EU Accession". LGBT Activism and Europeanisation in the Post-Yugoslav Space. On the Rainbow Way to Europe, ed. by B. Bilić, 23-58. London: Palgrave Macmillan.

Canaday, Margot. 2009. The Straight State. Sexuality and Citizenship in Twentieth-Century America. Princeton and Oxford: Princeton University Press.

Cossman, Brenda. 2007. Sexual Citizens. The Legal and Cultural Regulation of Sex and Belonging. Stanford: Stanford University Press.

De Certeau, Michel. 1988. The Practice of Everyday Life. Berkeley, Los Angeles, London: University of California Press.

Du Chesne, Louise, and Ben Bradley.2007. "The Subjective Experience of the Lesbian (M)other: An Exploration of the Construction of Lesbian Maternal Identity". Gay \& Lesbian Issues and Psychology Review 3 (1): 25-33.

Edenborg, Emil. 2017. Politics of Visibility and Belonging. From Russia's "Homosexual Propaganda" Laws to the Ukraine War. London, New York: Routledge.

Edwards, Jeanette. 2000. Born and Bred. Idioms of Kinship and New Reproductive Technologies in England. Oxford: Oxford University Press.

Evans, David T. 1993. Sexual Citizenship. The Material Construction of Sexualities. London, New York: Routledge.

Háttér Társaság. 2017. Azonos nemü szülők és gyermekeik. Kutatási összefoglaló. Downloaded April 24, 2018. http://hatter.hu/sites/default/files/dokumentum/ kiadvany/szivarvanycsaladok2017.pdf

Hayden, Corinne P. 2004. "Gender, Genetics and Generation: Reformulating Biology in Lesbian Kinship". Kinship and Family. An Anthropological Reader, ed. by R. Parkin, and L. Stone, 378-934. Boston: Blackwell.

Hovav, April. 2011. (Re)conceiving Kinship: Gay Parenthood through Assisted Reproductive Technologies in Israel. MA thesis. Budapest: CEU.

Imre, Anikó. 2008. "Lesbian Nationalism". Signs, 33 (2): 2552-82.

Kapitány, Ágnes, and Gábor Kapitány. 2007. Túlélési stratégiák. Társadalmi adaptációs módok. Budapest: Kossuth Kiadó.

Kipnis, Laura. 2000. "Adultery". Intimacy, ed. by L. Berlant, 9-47. Chicago, London: The University of Chicago Press.

Kuhar, Roman. 2011. "The Heteronormative Panopticon and the Transparent Closet of the Public Space in Slovenia". De-Centring Western Sexualities. Central and Eastern European Perspectives, ed. by R. Kulpa, and J. Mizielińska, 149-166. Farnham, Burlington: Ashgate.

Kuosmanen, Paula, and Jämsä, Juha. 200. Suomalaiset sateenkaariperheet sosiaali- ja terveyspalveluissa ja koulussa. Helsinki: Edita Prima Oy.

Lewin, Ellen. 1998. Recognizing Ourselves. Ceremonies of Lesbian and Gay Commitment. New York: Columbia University Press. 
Lewin, Ellen. 2009. Gay Fatherhood. Narratives of Family and Citizenship in Ameri$c a$. Chicago, London: The University of Chicago Press.

Lux, Elvira. 2008. Női szerepek a szexuálpszichológus szemével. Budapest: Saxum.

Mallon, Gerald P. 2004. Gay Men Choosing Parenthood. New York: Columbia University Press.

Manalansan, Martin F. IV. 2003. Global divas. Filipino gay men in the diaspora. Durham, London: Duke University Press.

Mészáros, György. 2018. “Az LMBT+ identitások és a mozgalom politikai gazdaságtana a félperiférián". Fordulat 24 (2): 215-241.

Nicolae, Lavinia M. 2009. "The marriage between kinship and sexuality in New Mexico's domestic partnership debate". Out in Public. Reinventing Lesbian/Gay Anthropology in a Globalizing World, ed. by E. Lewin, and W. L. Leap, 338-356. Chichester: Wiley-Blackwell.

Parkin, Robert. 2004. "Introduction to Terminology and Affinal Alliance". Kinship and Family. An Anthropological Reader, ed. by R. Parkin, and L. Stone,121-136. Boston: Blackwell.

Pateman, Carole. 1992. "Equality, Difference, subordination: the politics of motherhood and women's citizenship". Beyond Equality and Difference. Citizenship, feminist politics and female subjectivity, ed. by G. Bock, and S. James, 17-32. London, New York: Routledge.

Phelan, Shane. 2001. Sexual Strangers. Gays, Lesbians, and Dilemmas of Citizenship. Philadelphia: Temple University Press.

Plummer, Ken. 1997. Telling Sexual Stories. Power, Change and Social Worlds. London, New York: Routledge.

Plummer, Ken. 2003. Intimate Citizenship. Private Decisions and Public Dialogues. Seattle, London: University of Washington Press.

Polášková, Eva. 2007. "The Czech Lesbian Family Study: Investigating Family Practices". Beyond the Pink Curtain. Everyday Life of LGBT People in Eastern Europe, ed. by R. Kuhar, and J. Takács, 201-216. Ljubljana: Mirovni Inštitut.

Rédai, Dorottya. 2015. Sexing the School: Constituting Gender, Ethnicity and Class Through Discourses of Sexuality in a Hungarian Secondary School. Doctoral dissertation. Budapest: Central European University.

Renkin, Hadley Z. 2009. "Homophobia and Queer Belonging in Hungary". Focaal European Journal of Anthropology 53: 20-37.

Robertson, Jennifer. 2007. "Dying to Tell: Sexuality and Suicide in Imperial Japan". Women's Sexualities and Masculinities in a Globalizing Asia, ed. by S. E. Wieringa, E. Blackwood, and A. Baiya, 217-243. New York: Palgrave Macmillan.

Roseneil, Sasha, and Stoilova, Mariya. 2011. "Heteronormativity, Intimate citizenship and the Regulation of Same-Sex Sexualities in Bulgaria". De-Centring Western Sexualities. Central and Eastern European Perspectives, ed. by R. Kulpa, and J. Mizielińska,167-190. Farnham, Burlington: Ashgate.

Ryan-Flood, Róisín. 2009. Lesbian Motherhood. Gender, Families and Sexual Citizenship. Basingstoke: Palgrave-Macmillan.

Sahlins, Marshall. 2013. What Kinship Is - And Is Not. Chicago and London: University of Chicago Press.

Sandford, Theo. 2000. "Homosexuality, Psychology and Gay and Lesbian Studies". Lesbian and Gay Studies. An Introductory, Interdisciplinary Approach, ed. by T. Sandford, J. Schuyf, J. W. Duyvendak, and J. Weeks, 14-45. London, Thousand Oaks, New Delhi: SAGE. 
@ Sándor, Beáta. 2010. Mi vagyunk a család, a biztonság, az otthona. Leszbikus anyák, meleg apák és 'pótapák'. Budapest: Inter Alia Alapítvány.

Schneider, David. 1968. American Kinship: A cultural account. Englewood Cliffs, New Jersey: Prentice-Hall Inc.

Smith, Anthony D. 1991. National Identity. Reno - Las Vegas: University of Nevada Press.

Stella, Francesca. 2015. Lesbian Lives in Soviet and Post-Soviet Russia. Post/socialism and Gendered Sexualities. Basingstoke, New York: Palgrave Macmillan.

Sullivan, Maureen. 2004. The Family of Woman. Lesbian Mothers, Their Children, and the Undoing of Gender. Berkeley, Los Angeles, London: University of California Press.

Szalma, Ivett, and Takács, Judit. 2014. "Gyermektelenség - és ami mögötte van. Egy interjús vizsgálat eredményei”. Demográfia 57(2-3): 109-136.

Takács, Judit. 2008. Homoszexualitás és társadalom. Budapest: Új Mandátum.

Takács, Judit. 2011. "Homofóbia Magyarországon és Európában”. Homofóbia Magyarországon, ed. by J. Takács, 15-34. Budapest: L'Harmattan.

Takács, Judit, and Szalma, Ivett. 2013. “Az azonos nemű párok általi örökbefogadással kapcsolatos attitűdök Magyarországon”. Socio.hu 7: 1--33.

Tereskinas, Arturas. 2008. "Lithuanian Gays and Lesbians "Coming Out" in the Public/ Private Divide: Sexual Citizenship Lithuanian Style". Gender and Citizenship in a Multicultural Context ed. by P. Oleksy, and B. Waaldijk, 93-108. Frankfurt am Main: Peter Lang.

Weeks, Jeffrey. 1985. Sexuality and Its Discontents. Meanings, Myths and Modern Sexualities. London, New York: Routledge.

Weeks, Jeffrey. 1999. "The Sexual Citizen”. Love and Eroticism, ed. by M. Featherstone, 35-52. London, Thousand Oaks, New Delhi: SAGE. 
Переклад

Translation

○

Перевод 



\title{
Стигматизація аналітичної концепції ґендеру як ідеології
}

\begin{abstract}
$\mathrm{C}$
тигматизація «ґендеру» як категорії феміністичної ідеології стала центральним елементом політичного дискурсу в Угорщині з 2010 року. Відколи 1989 року змінилася система, я визначаю в цьому процесі три смислові вузли, які виникли та кристалізувалися в дискурси «ґендерної ідеології» та «ґендероманії». Таке переприсвоєння ключової категорії феміністичного аналізу - серйозний наступ, що має на меті не лише стигматизувати й огудити критичний потенціал «ґендеру», а й підважити саме його існування. У тексті я розмірковую про особливості цих змін та пропоную полівокальну модель значення, яка завжди відкрита до критики. Така соціально обумовлена модель потрібна нам, щоби повернути собі «гендер» як критичну категорію аналізу, створену для розвінчування ідеологічної потреби патріархальних інституцій ре/продукувати нерівні владні відносини як даність. Цей крок доволі нагальний, оскільки більшість дебатів, що точаться у феміністичних наукових та активістських колах Угорщини у відповідь на звинувачення в ідеології, зав'язли в суперечності між постструктуралістським уявленням про неуникну ідеологічність будь-яких значень i структурним (економічним) відчуженням жінок, яке претендує на «істинність» порівняно з хибнимими повістками політик ідентичності. Кожен із «таборів» завзято критикує своїх опонент_ок, загрузаючи в оберненні їхньої логіки, і здійсює те, що Лорен Берлан називає видовищним змаганням зі самознищення між скривдженими спільнотами в публічній сфері (Berlant 1996, 243).
\end{abstract}

Перекладено за текстом лекції, виголошеної Ержебет Борат у Києві 20 квітня 2018 року. Переклад підтриманий програмою "Сприяння демократії" представництва Фонду імені Гайнріха Бьолля в Україні. Наукова редакторка перекладу - Катерина Буркуш. 


\section{Епістемологічні рамки}

Аби зорієнтувати читач_ку в подальшій подорожі, хочу відразу визначити свою позицію. Як науковиця, що займається критичними студіями дискурсу, я розумію «ґендер» як соціальну практику розрізнення, що виникає зсередини інституційно регульованих практик. Його важливим установчим елементом $є$ символічний акт означення, тобто кодування матеріальних практик, у які ми безпосередньо залучені, а також інших, які ми не здійснюємо, але про які думаємо з погляду наявної практики. Словом, практики завжди зумовлюють категоризацію. Категорії, які при цьому виникають, вростають у порядки цінностей, показові для інституцій, у чиїх рамках вони формуються як концепції з певним значенням. Найважливіший елемент запропонованого визначення - це твердження, що розуміння практики, в яку ми залучені, неможливе без артикулювання множинних рефлексій про інші практики в різних місцях, моментах часу та системах цінностей. Це означає, що модель, яку я пропоную, за своєю суттю множинна: сформовані категорії впорядковуються саме за принципом множинності. Виникнення категорії як цілісної, а отже значущої схеми уможливлюється завдяки діалектичному процесу часткової інтеграції різноманітних значень із елементів значення, які завжди стосуються інших множинних полів практики (тобто з інших категорій), а в результаті - взаємодії домінантних відносин панування.

У запропонованому аналізі стигматизації гендеру за відправну точку я беру категорію маскулінності. Я розумію, що такий вибір може викликати розчарування, адже більшість простору та уваги й так уже привласнили чоловіки. Взаємозв'язок жінок і влади завжди був непростим ${ }^{1}$. Проте щоби викрити та зрозуміти привілеї, задіяні в наявній системній дискредитації гендеру як ідеології в дискурсі угорської політики, нам необхідно виявити тривожні та розхитані гендерні відносини влади, мобілізовані «скривдженим відчуттям права маскулінності», яке підживлює відчай і лють у різних груп чоловіків. Існує небезпека, що внутрішні розколи у феміністичних групах можуть зіграти на руку цій люті.

P. В. Конел (Connell 1987) запропонувала концепцію гегемонної маскулінності на противагу панівним підходам до гендеру в тогочасній соціології. Дослідниця підважила загальноприйняту концептуалізацію цієї категорії як самодостатнього набору заданих наперед рис характеру, що мають збігатися з «біологічно визначеною статтю», а отже повинні мати відповідну типологію «ґендерних ролей», які буцімто набуваються в односторонньому розвитковому процесі соціалізації, зверху вниз. Як не парадоксально, канонізована модель статі концептуалізується че-

\footnotetext{
${ }^{1}$ Див. наприклад, Sreberny and van Zoonen 2000, Vavrus 2002, чи Lakoff 2003. Усі ці праці розглядають конфліктні відносини у сфері медій - головного дискурсивного поля, звідки я беру свої дані.
} 
рез практику категоризації, яка привілеює «чоловіче» як «очевидний» принцип категоризації, укорінений у біології, а відтак продукує розрізнення бінарного протиставлення за рахунок «жіночого». Така бінарність підштовхує дослідни_цю до вивчення лише певних соціальних дій, пов'язаних із «двома статями», та до розгляду їх як таких, що стосуються тієї чи іншої «ґендерної ролі». На думку Конел, за межі цієї гомогенної статичної практики категоризації можна вийти, вбачаючи у гендері активний процес узгодження, результат якого (включно з категорією біологізованої статі) формується панівними владними відносинами. 2005 року Конел знову повертається до цієї моделі разом із Джеймсом В. Месершмідтом (Connell and Messerschmidt 2005), щоби перевірити, чи не втратила вона пояснювальної сили у світлі спричинених глобальним капіталізмом соціальних змін. Дослідники дійшли висновку, що концепцію слід зробити більш динамічною. Завдяки цьому, на мою думку, вони змогли запропонувати складніше пояснення суспільних змін - крізь призму маскулінності. Науковці закликають визнати множинність маскулінностей і заохочують дослідни_ць вивчати, на додачу до гегемонної, інші форми (як-то робітник, який виконує фізичну працю; білий гей середнього класу; субкультурний фанат хардроку; непрацевлаштований ром-містянин тощо). Це допоможе продемонструвати продуктивність інших форм і зрозуміти, що всі зміни в ідеальній формі маскулінності $€$ результатом боротьби стигматизованих, виключених, знецінених чи допустимих маскулінностей, які кидають виклик і підважують цінність і позицію, приписану їм через відносини панування.

Проте на підставі заявленої епістемологічної позиції щодо множинності як фундаментальної характеристики значення, я стверджую, що нам потрібно зробити і цю модель маскулінності ще більш динамічною. Ідеальна (чи ідеалізована) форма маскулінності стає такою, якою ï̈ сприймають, завдяки суперечливим відносинам із різними іншими формами маскулінності шляхом соціально регульованого процесу погодження їхньої цінності. Тож нам необхідно зробити ще один дуже важливий крок і подумати про те, як ми розуміємо «відносини». Я стверджую, що багатоголосся чи гетерогенність характерні для всіх категорій, оскільки вони стають більш-менш цілісними саме завдяки об'єднанню кількох інших дискурсивних елементів/категорій. Отримана в результаті категорія частково збігається з тими, з якими вона має спільні елементи. Відповідно, про межі категорій не варто думати як про самодостатні. Вони частково збігаються, що робить їх відносно стабільними та завжди відкритими до реконфігурації. Водночас, коли ми говоримо про можливість зміни, то йдеться не лише про логічну спроможність, а й про політичну життєздатність у даний історичний момент. I саме це встановлює відносні, але доречні обмеження для нашої (наукової чи активістської) уяви. Різноманітні вектори владних відносин, залучені до процесу зміни, визначають, що саме можливо уявити в цю історич- 
ну мить у рамках даного інституційного простору. Отже, новоутворені патерни значення є результатом не випадкової взаємодії означників, а соціально регульованої дискурсивної артикуляції довільності.

Із мого тлумачення цього аргументу випливає, що значення - сформований концепт - ідеологічне, оскільки покликане натуралізувати, применшити чи представити цю довільність або як геть не передбачувану, або як неминуче гомогенізовану даність. Хоча ці позиції суперечать одна одній, вони обидві опираються усвідомленню, що лише певні значення, які виникають у побудованій на виключенні матриці влади, змушують деякі значення функціонувати як стигма. Догму універсальної істини, яку використовують проти інших значень, позначаючи їх як хибну свідомість чи як ідеологію, підважують випадковим зібранням означників. Тому нам слід визнати, що всі значення - ідеологічні. Тобто бодай уявити політично реальний момент рівноправ'я неможливо. Натомість маємо нескінченні потоки гегемонних (тобто ієрархічних) реконфігурацій відносин влади та категорій іменування. Попри виклики нескінченної довільності та наслідки ідеологічності будь-якого конструювання значення, існує одна річ, яку ми можемо виявити: нескінченна довільність не конче перебуває у бінарних відносинах з імовірністю. Достатньо, аби задіяна тут логіка артикуляції була заснована на частковому розрізненні. Ідеться про те, щоби категорію, яку сприймають доволі інакшою, визнали достатньо відмінною, а тоді подивитися, чи множинні вектори значення можуть продукувати конфігурацію рівноправ'я. Це перегукується із твердженням Деніс Томпсон (Thompson $2001,27):$ «и завжди перебуваємо у системах значень. $Є$ вони ідеологічними чи ні, залежить від того, чи їх використовують із метою панування». Відштовхуючись від ідеї Томпсон, я стверджую, що довільна модель значення, яка виникає на перетині множинних соціально регульованих практик означення, може допомогти нам уявити й узгодити конфігурацію, у якій матриця владних відносин буде сформована не гегемонією. Відтак, значення залучених у процес категорій може бути артикульоване без ідеологічних посилів. На мою думку, у феміністичних дебатах щодо того, яку позицію слід зайняти для ефективної протидії сучасній кампанії з дискредитації фемінізму як гендерної ідеології, треба бути готовими вийти за межі бінарного сприйняття соціальної ситуації як такої, що протиставляє (структурну) дійсність завжди ідеологізованим культурним конструкціям (політикам ідентичності). Натомість треба прийняти розуміння встановленої, дискурсивно артикульованої полівокальності значення (включно із категорією ґендеру).

3 огляду на те, що множинні відносини гегемонного панування утворюють сучасний статус-кво, ефективність конкретної ідеології залежить саме від того, наскільки значення близькі, ба навіть наскільки їм вдається уникнути (критичного) розпізнавання, тому що вони сприймаються як звичний «здоровий глузд» та безперечна «істина». Саме це і 
сталося за останніх дев'ять років зі значенням гендеру: його перевизначили як небезпечну ідеологію, яка, відтак, стала легітимною мішенню для ненависницьких нападок. Ситуація в Угорщині унікальна, тому що тут цим дискурсом маніпулюють зсередини різних інституцій державної влади. Отже, наше завдання полягає не в тому, щоби заперечувати звинувачення. Нам необхідно зосередитися на питанні «як підступитися до чинних державних ідеологій, залучених у цій кампанії, особливо тої/тих, які зараз є панівними?» Саме тому, на мою думку, нам необхідно вивчити та підважити «здоровоглузді» значення гендеру в науковому та ненауковому дискурсах. Як і Майкл Біліг (Billig 1995), я виступаю проти злиття банального та незагрозливого в одне ціле під час оцінювання різноманітних форм «невипнутого» націоналізму в політичному дискурсі. Я наполягаю, що небезпечно не досліджувати явища, які в науковій літературі часто знецінюються узвичаєним відсиланням до банальності, а отже й неважливості концептів «здорового глузду». Доходить до того, що про них говорять: «А що в цьому нового?» Небезпечно ігнорувати ту обставину, що сприйняття чогось як незагрозливого дозволяє прирівняти його до «очевидного», до «здорового глузду». Тому нам потрібно намагатися протидіяти такому злиттю понять і здійснювати відносне, проте значуще розрізнення між банальним та незагрозливим. Словом, я також стверджую, що концептуалізація «відносності» як історично обумовленого діалектичного, частково інклюзивного формування взаємин стосується також концептуалізації «відмінності». Згідно з моделлю дискурсу Джеймса Пола Гі (Gee 2014), диференціація - це дискурсивний акт творення значення, який виникає внаслідок множинних вимірів практик кодування, що надає перевагу одному патерну значень над іншим, оскільки цей патерн достатньо узгоджений із тим, що сприймають як зрозуміле в даному соціальному просторі без будь-яких додаткових міркувань, тобто як здоровий глузд.

\section{Три смислові вузли, що доклалися до дискредитації «ґендеру»}

Особливості порядку політичного дискурсу останніх трьох десятиліть в Угорщині можна дослідити крізь призму змін у значенні фемінізму та гендеру. Передусім, потрібно зрозуміти, де теперішній угорський офіційний політичний дискурс розташований у картографії гендерного знання. Цей дискурс можна охарактеризувати за рутинними нападками на права жінок, сексуальних меншин і людей із неконформними ґендерними ідентичностями, а також феміністичних науков_иць в умовах посилення правого популізму, коли мова ненависті увійшла до повсякденного мовлення². Стигматизація «гендеру» як ідеології стала цен-

2 Грунтовну критику такого популістського політичного дискурсу викладено в моєму новому дослідженні (Barát 2017). 
тральним елементом державного політичного дискурсу в Угорщині 3 2010 року. $^{3}$

Відколи 1989 року змінилася система, я можу визначити три смислові вузли творення значення ґендеру, які кристалізувались у загальноприйняті правопопулістські дискурси про ґендерну ідеологію та «гендероманію». На жаль, часом трапляється, що їх опосередковано поширюють у різних публічних дебатах і публікаціях люди, які самі себе зараховують до феміністичної опозиції4. Перший період припадає на 1990-ті роки. У той час різноманітні практики творення значення стосувалися терміну «фемінізм» і розгорталися переважно на шпальтах друкованих політичних видань. Значення фемінізму виникло на перетині трьох панівних дискурсів і дуже швидко сплюснулося у фігуру страшної феміністки, якій бракує розуму, щоб оцінити шкідливі наслідки фемінізму, визначені медіями. Проте, оскільки феміністок репрезентували як купку ненормальних жінок, цільова аудиторія різних медій почувалася захищеною завдяки трансльованому ними обуренню, а також власному розототожненню з такими небезпечними постатями. Перший із трьох дискурсів, про які йдеться, - це антиамериканський дискурс, що вбачав у фемінізмі завезену з чужини загрозу нещодавно відвойованій країною автономії, а також заявленим інтересам жіноцтва, якому не варто підхоплювати божевілля американських посестер. Вони ж бо зайшли «надто далеко» і судяться (головно з багатими знаменитими чоловіками) через безпідставні звинувачення в сексуальних домаганнях - чи то через жадобу, чи то через лесбійську ненависть до чоловіків. До такого значення доклався й інший прилеглий дискурс, який звинуватив жінок-феміністок в ігноруванні власного досвіду: «жіноче питання» належить до провального комуністичного минулого, а ідеальна «нова жінка» зміненої системи, вочевидь, мусить прагнути розпрощатися з цим минулим. Зрештою, жінка-феміністка $є$ невдахою навіть із погляду самого фемінізму, оскільки відмовляється визнати важливість жіночих способів знання [women's way of knowing], зокрема, заперечуючи добробут, про який говорять більшість сучасних жінок.

Я детально зупинялася на цих характеристиках у попередніх публікаціях (Barát 2005). Тут я хочу підкреслити, з одного боку, механізм гейткіперства (відбору та фільтрування інформації) медіями. Він давно бере участь у дискредитації фемінізму як ідеології, визначаючи його як

\footnotetext{
${ }^{3}$ Взагалі системні словесні нападки кульмінували 13 серпня 2018 року законопроєктом про заборону внесення дисципліни гендерних студій до державного списку магістерських ступенів. Після цього його видалили 3 державного реєстру ступенів 13 жовтня актом публікації у Державному бюлетені без жодних подальших публічних оголошень. Проте, коли я працювала над представленою в даній статті аргументацією, ці події ще не відбулися, і я не могла їх розглянути ретроспективно. На жаль, на підставі траєкторії моєї аргументації цілком можна було очікувати державного втручання.

${ }^{4}$ Прикладом недавньої публікації, яка повторює та підтримує такий шкідливий розподіл, є Grzebalska, Kováts and Pető 2018.
} 
нову імперіалістичну (американську) ідеологію, переплетену зі старою комуністичною, що пригноблює спосіб життя «інших» жінок. 3 другого боку, моє дослідження від 2005 року показало, що той невеликий простір, який медії надавали для феміністичних самовизначень у відповідь на ворожі практики іншування, був просякнутий ворожими гегемонними дискурсами про гендер у медіях. Цей дискурс, з одного боку, представляв науковиць-реформісток, що, як не дивно, поділяють мізогінне чоловіче бачення гетеросексуального міфу про жінок і чоловіків як партнер_ок у взаємодоповнюваних стосунках, а з іншого - гарантував майже повну відсутність репрезентації критичних голосів табуйованої сексуальності. Словом, потенційно автономні голоси лунають саме 3 жорстоко маргіналізованих негетеросексуальних позицій:

І це стало спільною точкою відліку для створення мізогінного гегемонного альянсу (гетеро)сексистського чоловічого та реформістського феміністичного голосів. Нехай і з різними мотиваціями, цей альянс стає на захист гетеро-гендерованого соціального ладу... (Дискурсивні) практики можна вважати ідеологічними, адже вони мають на меті утримувати статус-кво через натуралізацію даних гегемонних відносин патріархальної влади... різні типи дискурсів, залучені у визначення «фемінізму», посилюють патріархальну регуляцію жіночої праці та жіночого бажання саме через розуміння гендеру наперед визначеним через стать (Barát 2005, 206-7).

Перше десятиліття XXI століття може видатися порівняно спокійним, оскільки тоді було менше спроб дати визначення фемінізму для широкої громадськості ${ }^{5}$. Ці процеси відбувалися переважно в наукових закладах, а медії та інші політичні інституції не висловлювали безпосереднього зацікавлення. Третій період почався після парламентського обговорення державної навчальної програми для дошкільнят. Воно відбулося у розпалі партійної боротьби на фініші державних виборів. Проте цього разу зайшлося не про фемінізм, а про ґендер, який відтоді почав функціонувати як пустий означник, згідно з термінологією, запропонованою Ернесто Лакло (Laclau 1996, 44). На мою думку, однією із найбільш очевидних характеристик правого популізму $є$ творення суспільних відносин між деякими двома пустими означниками як непримиримої суперечності через узвичаєне використання мови ненависті. 3 одного боку, така логіка продукує гомогенізовану «маскулінність», завдяки якій різноманітні соціальні групи «наших» чоловіків можуть легко та прудко об'єднатися, щоби пере/осмислити себе як «сильних» захисників нації від будь-якої події, інституції чи колективу, яких проголошують «ворожою шкідливою загрозою». Водночас залишається непоміченим той факт, що таке відчуття «справедливості» та «легітимності» засноване на пригнобленні різноманітних «інших». У своїх правих популістських заявах угорський уряд посилається на «силу» нації, якою він

${ }^{5}$ Детальне обговорення цього періоду викладено в публікації (Barát 2012), доступній лише угорською мовою. 
наділений, щоби «захищати» християнські сімейні цінності «справжньої Європи» від «інших» чоловіків та гомогенізованих мусульманських «зайд». Опосередковано уряд покликаний «захищати» від «схиблених» на грунті гендеру та прав людини «спонсорованих Соросом» громадських організацій, а також від будь-яких досліджень чи викладання, які можуть підтримувати чи буквально «прикривати» «вторгнення». Оскільки пустий означник «загрозливого для нас чужинця» збирає навколо себе усі ці різноманітні групи та події, така ідеологічна робота $\epsilon$ бажаною, адже завдяки їй будь-хто може стати мішенню для нападок, після чого просто чіпляється ярлик «одного з них», і цей ярлик уже не потребує подальшого пояснення чи виправдання.

Хоча на початку минулого десятиріччя гендер був терміном, що викликав надривні реакції під час обговорень у парламенті, пропоновані урядом зміни мали на меті популяризувати толерантність у двох випадках. Вихователь_кам у дошкільних закладах рекомендували вибирати вправи, які б підважували ґендерні стереотипи та популяризували мультикультуралізм. Прикметно, що під час обговорень цю другу пропоновану зміну навіть не було названо проблемною. Християнсько-демократична народна партія, яка найзапекліше виступала проти зміни - i ще місяць після дебатів залишалася в опозиції - ще не бачила тоді жодної загрози в інших культурах. Їхньою реакцією на помірковані спроби уряду запровадити ґендерний мейнстримінг було те, що ворогом номер один для них став саме «ґендер». Вони прямо атакували цю запропоновану зміну, оскільки «ґендер» для них був ідеологічним кодом, що «приховував справжню мету»- змусити «наших дітей» втратити відчуття чоловічої чи жіночої ідентичності й таким чином «проштовхнути» приховану повістку «третьої статі». Лівоцентристський уряд звинуватили в нападі на «власний народ», і християнські демократи пообіцяли скасувати цю нову політику, щойно прийдуть до влади. Вони виконали свою обіцянку відразу після інавгурації нового міністра освіти (ним стала та сама людина, яка розкритикувала дії лівоцентристського уряду як прихований план «ліберального гей-лобі»). Лише після того, як улітку 2015 року через балканський шлях до Угорщини потрапили біжен_ки із Сирії, прихильни_ці ідей про загрозу з боку «мігрант_ок» та «ґендероманії» зійшлися щодо двох взаємопов'язаних порожніх означників мови ненависті, яка вже стала звичним способом комунікації в країні. На відміну від решти Європи, цей режим дискурсу ненависті продукують державні політичні інституції та посередники, вони ж визначають мішені для ненависті та просувають свою візію.

За час першої каденції правоцентристського уряду в 2010-2014 роках дискредитація ґендеру головно здійснювалася чинними парламентарями-учасниками урядової фракції, які атакували виступи жінок-парламентарок з опозиції під час розгляду законопроєктів чи в питаннях, які ставили член_киням уряду під час обговорень. Дуже показовими були скеровані проти них принизливі вислови з лексикону мови не- 
нависті під час обговорення законопроєктів про криміналізацію домашнього насильства. Хоча закон і прийняли в другому читанні, тепер він головно спрямований на захист дітей, і насильство не називається «домашнім», оскільки це би пов'язувало дім та сім'ю з сексуальним/фізичним насильством, що нібито неможливо за визначенням. Натомість його називають «насильством у партнерстві». Під час суперечок із приводу законопроєкту логіка деяких промов перегукувалася з ліберальною феміністичною повісткою захисту прав жінок. Звучали твердження, що якби жінки «спершу народили достатньо дітей» (уточнювалося, що йдеться про трьох-п'ятьох дітей), то причин для насильства не було б... (sic). Під час другої каденції правлячого режиму, у 2014-2018 роках, контекст творення мови ненависті та вибору «належної мішені» зміщується з парламентар_ок при владі на людей, які займають високі посади. Голова парламенту, наприклад, неодноразово висловлював переживання стосовно того, що жінки не хочуть народжувати «для нас онуків». Під час цього інтенсифікованого етапу він також чітко окреслив причину «смерті нації»: це, буцімто, «ґендерна ідеологія», «ґендероманія». Зрештою, з квітня 2018 року нападки на «ґендер» стали частиною загальної кампанії дискредитації і згортання свобод та автономії науки. Певною мірою стигматизація «ґендеру» та будь-кого із ним пов'язаної з боку влади зараз сягнула найвищого рівня. Ставлячи під сумнів науковий статус гендерних студій та їхню ключову категорію критичного аналізу і тавруючи їх як чисту ідеологію, влада приписує акт власного політичного втручання фігурам наукового поля.

\section{У тривожному очікуванні}

Я вважаю, що за такихумов можна зробити дві важливі речі. По-перше, створити мережі солідарності, які підважуватимуть апелювання до національного «ми». Оскільки саме таку риторику популістські політичні режими в усьому світі використовують у відповідь на різноманітні кризи глобального неоліберального капіталізму, нам треба шукати одна одну та об'єднуватися. На мою думку, для цього потрібно створити порожній означник для лівиці, концепція ідентичності якого визнаватиме, що множинність - необхідна умова його утворення. Нам треба шукати способи уявити інклюзивний акт приналежності, який уникав би тенет ліберального дискурсу гуманізму, який наповнює різноманітні повістки інтеграції, хоча станом на сьогодні вони й стають дедалі слабшими у всьому ЄС. Для цього ми можемо звертнутися до концепції вразливості [vulnerability] Джудит Батлер (Butler 2004). Ця концепція особливо важлива, адже Батлер розвиває їі, міркуючи про можливість колективної дії та про форми політичних зібрань. Дослідниця апелює до спільного стану людської вразливості, нашого відчуття прекарності та жорсткої економії. Їх, за онтологією Батлер, ніхто не може позбутися, оскільки без цієї первинної вразливості до інших ми перестаємо бути 
людьми (Butler 2014, XIV). 3 огляду на примусові стратегії світової влади, які застосовують до мільйонів переміщених осіб, мільйонів жінок і дітей, яких втягнули в торгівлю людьми, я думаю, саме така диференційна, квірна логіка може оприявнити нерівномірний розподіл шкідливих впливів токсичної маскулінності.

Я вбачаю у втечі біжен_ок до Європи чи нещодавніх протестах бразильських та польських жінок проти обмеження права на аборти форму «дієвого перформативного тілесного спротиву, який демонструє нам як на тіла діють соціальні та економічні політики, що винищують засоби для існування» (Butler 2015, 10). Проте це також $є$ ознакою неймовірної снаги цих людей, які через демонстрацію своєї отілесненої прекарності чинять спротив саме тим силам, які проголошують життя біжен_ок «одноразовими», не вартими оплакування.

Поняття спільної прекарності Батлер розглядає як бажанішу повістку, аніж політики ідентичності. В їі розумінні воно дозволяє сформулювати ширше, не виключне розуміння «вимог» на підставі онтологічної умови вразливості (людського) життя. Втім, на мою думку, включення - це не справа масштабу, як можна подумати, якщо ми оперуємо поняттями ширшого/вужчого обсягу. Парадоксально, але інклюзивність пустого означника, відмінна від численних моделей стигмувального виключення у правому популізмі, можлива завдяки специфічній концептуалізації категорії прекарності. Вона дозволяє уявити спільну вимогу гідного життя в публічних просторах через політичний акт множинної перформативності - запрошення усіх потенційних прихильни_ць об'єднатися з тими, кого це безпосередньо стосується. Я стверджую, що спільність не обов'язково неможлива у разі політичних актів мобілізації навколо «ідентичності». Ідентичність (колективна чи індивідуальна) не конче мусить працювати завдяки утворенню та утриманню нормативних уявлень про приналежність та неприналежність, за умови, якщо категоризація відбувається через відносне, а не абсолютне розрізнення між явною та прихованою мішенню ненависті ${ }^{6}$. На мою думку, розрізнення, яке пропонує Батлер, продукує бінарність між спільністю, яка асоціюється з універсальною уявною людською умовою вразливості над/насупроти формулювань окремих вимог, пов'язаних 3 ідентичністю.

Якщо ми погодимося із онтологічним засновком, що висловлювання, аби стати зрозумілими, структуруються плюральністю чи множинністю, і що значення будь-якої категорії, у тому числі ідентичності й прекарності, за визначенням багатоголосе чи діалогічне, тоді всі категорії формуються під впливом такої множинної логіки. Плюральність, як логічна випадковість, - це невід'ємна частина усіх категорій. Відповідно, ідентичність «я» чи «ми» завжди підважується через диференційовані

\footnotetext{
${ }^{6}$ Про важливість включення «решти» даного суспільства, а не лише безпосередньо обраної групи, див. у Matsuda et al. 1993.
} 
способи взаємин з іншими. Для мене завдання полягає не в доведенні, що ідентичність як категорія неспроможна пояснити, як це - жити та діяти етично разом, тоді як прекарність може, адже вона завжди орієнтована на включення. Радше варто дослідити генеалогію самих категорій, зрозуміти, чи дані історичні умови прихильніші до розуміння прекарності, чи роблять її більш привабливим концептом, аніж ідентичність. Нам слід дослідити, чому прекарність здається перспективнішою категорією сучасної політичної думки, аніж ідентичність. Панівне значення ідентичності сьогодні присвоєне суспільством споживання: це питання стилю життя, щось, що завжди можна мобілізувати через етику індивідуалізованого відчуття провини. Можливо, концепція прекарності видається більш продуктивною в політичній думці тому, що вона ще не осіла настільки, аби стати такою ж «очевидною», як ідентичність - і в наукових, і в ненаукових дискурсах прогресивної політики, коли йдеться про людей як про групу, об'єднану приналежністю до чогось. Утім, ми можемо стверджувати, що пустий означник, який апелює до прекарності, може витворити «нас», адже його теперішнє значення може краще актуалізувати ту обставину, що соціальне життя базується на взаєминах: «Наше життя завжди певною мірою в руках інших. Це означає бути відкритими і до тих, кого ми знаємо, і до тих, кого ми не знаємо; залежати від людей, яких ми знаємо, ледве знаємо або не знаємо взагалі» (Butler 2009,14).

Barát, Erzsebet. 2017. "Populist discourses in the Hungarian public sphere: From right to left (and Beyond)?" Journal of Language and Politics 16 (4): 535-50.

Barát, Erzsebet. 2012. "A 'politikai korrektség'-re hivatkozás ideológiai csapdái: A 2010-es év óvodapedagógiai változtatásokra tett kísérletet kísérő társadalmi és politikai küzdelmek." Gondolatok a toleranciáról, a másságról. Mi/Más 2. Konferencia 2010, ed. by Kádár Judit és Szathmáry Judit, 66-74. Eger: Esterháry Károly Főiskola.

Barát, Erzsebet. 2005. "The 'Terrorist Feminist': Strategies of Gate-Keeping in the Hungarian Printed Media." Feminist Critical Discourse Analysis: Gender, Power and Ideology in Discourse, ed. by M. M. Lazar, 205-228. London: Palgrave.

Berlant, Lauren. 1996. The Queen of America Goes to Washington City. Essays on Sex and Citizenship. Durham, NC: Duke University Press.

Billig, Michael. 1995. Banal Nationalism. Thousand Oaks, CA: Sage.

Butler, Judith. 2004. Precarious Life - The Powers of Mourning and Violence. London and New York: Verso.

Butler, Judith. 2009. Frames of War. When is life grievable? London and New York: Verso.

Butler, Judith. 2015. Notes Toward a Performative Theory of Assembly. Cambridge, MA: Harvard University Press.

Connell, R.W. 1987. Gender and Power. Society, the Person and Sexual Politics. Hoboken, NJ: Wiley.

Connell, R.W. and James W. Messerschmidt. 2005. "Hegemonic Masculinity." Gender and Society 19 (6): 829-859. 
102 Критика феміністична 2021, 4

따 Gee, James Paul. 2014. An Introduction to Discourse Analysis: Theory and Method. Abingdon: Routledge.

Grzebalska, Weronika, Eszter Kováts, and Andrea Pető. 2018. “Gender as symbolic glue. How 'gender' became an umbrella term for the rejection of the (neo)liberal order." Breaking Feminism, ed. by L.M. Deese et al., 32-38. Berlin: Rosa Luxemburg Stiftung.

Matsuda, Mari J., Charles R. Lawrence, Richard Delgado, and Kimberlé Crenshaw. 1993. Words That Wound: Critical Race Theory, Assaultive Speech, and the First Amendment. Colorado and Oxford: Westview Press.

Lakoff, Robin. 2003. “Language, Gender, and Politics: Putting 'Women' and 'Power' in the Same Sentence." The Handbook of Language and Gender, 160-178. Hoboken: Blackwell Publishing Ltd.

Sreberny, Annabelle and Liesbet van Zoonen, eds. 2000. Gender, Politics and Communication. Cresskill, N.J.: Hampton Press.

Thomson, Denise. 2001. Radical Feminism Today. Thousand Oaks, CA: Sage.

Vavrus, Mary Douglas. 2002. Postfeminist News: Political Women in Media Culture. Albany, N.Y.: State University of New York Press. 


\section{Рецензії \\ Reviews \\ Рецензии}





\section{Некрополітика, гомонаціоналізм і вразливі квір-життя в часи глобального неолібералізму}

Jin Haritaworn, Adi Kuntsman and Silvia Posocco, eds. Queer necropolitics. London: Routledge, 2014.

$\mathrm{B}$ Україні для багатьох активістських груп «західне» законодавство й політика в царині ЛГБТ-прав часто є зразком для наслідування. Натомість збірник статей «Квір-некрополітика» за редакцією Джин Харітаворн, Аді Кунцман і Сільвії Посокко звертає увагу на проблемні місця боротьби за рівність. Представлені дослідження демонструють, що вповні користуватися свободами може тільки привілейована частина ЛҐБТ-спільноти (зазвичай це білі ґеї з середнього класу). Натомість економічно та політично вразливі групи, як-от люди кольору чи транс*фемінні мігрантки, залишаються за бортом змагання за рівні права. Важливо, що не тільки владні інституції оминають увагою ці верстви, а й провідні ЛГБТ-організації «не помічають» упосліджених груп усередині своєї спільноти.

Фокусуючись передусім на прикладах зі США й частково Ізраїлю, Британії та Гватемали, статті збірника використовують концепцію некрополітики Акіля Мбембе, аби дослідити взаємозв'язки між квір-спільнотами $^{1}$ та біополітичним насильством владних структур. У тепер уже класичній статті «Некрополітика» (2003) Мбембе вивчає, як влада реалізовується через некрополітику, тобто через соціальне й політичне управління життями та смертями населення. Дослідження Мбембе резонує з попередніми дискусіями про біовладу Мішеля Фуко. Як і Мбембе, Фуко розглядає владні стратегії привласнення й дисциплінування тіл. Однак у центрі фукіанських біополітик, передовсім, практики, спрямовані на забезпечення та продовження продуктивного життя. Мбембе натомість досліджує «політику смерті». Інакше кажучи, він аналізує, як влада маркує певні категорії населення «непотрібними», а відтак приреченими на соціальну чи навіть фізичну смерть. Власне, опираючись на твердження Мбембе, автура «Квір-некрополітики» наголошує, що значна частина квір-людей, а то й цілі квір-спільноти є об'єктами некрополітики. Окрім того, відсилаючи до тези Джудіт Батлер про «оплакуваність» життя, автор_ки збірника запитують: чому життя одних вважається цінністю і їхню смерть оплакують, тоді як життя і смерть інших лишаються непоміченими й неоплакуваними? Важливо, що пред-

\footnotetext{
${ }^{1}$ У книзі та цій рецензії поняття «ЛГБТ-спільноти» та «квір-спільноти» вжито як взаємозамінні.
} 
ставлені у книжці дев'ять статей досліджують некрополітику влади як щодо своїх громадян_ок, так і щодо населення інших країн у межах так званої «боротьби з терором».

Використовуючи концепцію «квір-некрополітики» Джасбір Пуар, частина авторського колективу стверджує, що неоліберальні режими привласнили риторику боротьби за права людини задля виправдання неоімперської зовнішньої політики. Наприклад, статті Джейсона Рітчі та Сіми Шаксарі демонструють, як уряди США й Ізраїлю через підтримку ЛҐБТ-прав створюють собі міжнародний імідж демократичних і правових держав. Адже під гаслом «боротьби за свободи» їм легше провадити агресивну політику проти начебто нетолерантних мусульманських суспільств. Важливо, що свідомо чи несвідомо провідні ЛГБТ-організації стають «співучасницями» проєкту нового імперіалізму. Гомонаціоналізм, себто «шлюб» націоналізму та ЛҐБТ-політик, став новою формою ксенофобії, спрямованої на боротьбу проти ісламського світу. Скажімо, Рітчі показує, що, формуючи образ квір-палестин_ця як жертви гомофобії, впливові ізраїльські ЛГБТ-організації долучаються до репрезентації Палестини як простору насильства. У такий спосіб вони відрожевлюють [pinkwash] агресивну політику Ізраїлю на палестинських територіях.

Подібний аргумент наводить Шаксарі у статті «Убий мене ніжно своїми правами», що розглядає американську війну з тероризмом крізь призму некрополітики. Зокрема автор стверджує, що американська «гегемонна репрезентаційна політика не тільки породила універсалізовані сексуальні ідентичності, які були мобілізовані відповідно до логіки американського гомонаціоналізму, а й спричинилася до управління життям і смертю різних груп населення» (95). Наслідком цієї політики, з одного боку, стала висхідна популярність образу патріотичного гея (у своїй статті Шаскарі аналізує приклад Марка Бінггема), яким зазвичай $\epsilon$ білий маскулінний чоловік. 3 іншого боку, мусульманське населення репрезентують як гомофобне й відстале від цивілізованого світу. Утвердженню такого стереотипу сприяють медіа та правозахисні ЛҐБТ-організації, що, наприклад, попри відсутність перевіреної інформації, показали страту через повішення ґеїв Махмуда Асгарі й Аяза Мархоні в Ірані як варварське вбивство на грунті гомофобії. Натомість ЛГБТ-організації часто ігнорують важке становище іранських транс*біженц_ів, залишаючи їхні прекарні життя та смерті непоміченими. Власне, така вибіркова репрезентація смерті веде до створення некрополітичних ієрархій, які $\epsilon$ об’єктами критики не тільки статті Шаскарі, а й усього збірника.

Кілька статей досліджують місця - за Мбембе, «світи смерті» [death worlds], - де різні квір-середовища стають приреченими на соціальну, а подекуди й фізичну смерть. Написана науковцем і активістом трансгендерного руху Елая Едів Едельманом стаття «Гуляти у трансґендерному 
стані» ${ }^{2}$ розглядає просторову політику американської столиці, фокусуючись на так званих «зонах, вільних від проституції». Зокрема автор критикує політику джентрифікації, яку називає практикою некрополітичного капіталізму, за те, що тільки «економічно продуктивні» люди можуть жити в добрих умовах, тоді як економічно непродуктивні - 3 перспективи неоліберального капіталізму - «стираються» 3 міського ландшафту. Це дослідження, базоване на понад 100 інтерв'ю та суб'єктивних просторових мапах транс*фемінних людей (багато з яких займаються проституцією), демонструє, що вже сама поява транс*людей, а особливо трансжжінок кольору в просторі міста криміналізується. При цьому, як стверджує автор, ані міська влада, ані локальні ЛГБТ-організації не цікавляться нападами та вбивствами транс*людей, залишаючи більшість із них нерозкритими.

Тим часом Сара Ламбл розглядає американську карцеральну систему як іще один простір некрополітики. Авторка звертає увагу на трансформацію ставлення до каральної політики серед ЛҐБТ-спільнот у США та Британії. Якщо рух за ЛГБТ-права розпочинався із квір-протесту проти карцеральної держави, то зараз ЛГБТ-спільнота «перейшла на бік держави» і заохочує каральні заходи щодо певних категорій населення. Для прикладу авторка показує, що лондонська квір-організація «Веселкові селища» використовувала законодавство про злочини на грунті ненависті як каральний інструмент стосовно ісламського населення, вимагаючи не штрафу, а ув'язнення мусульманина за поширення гомофобних плакатів. 3 огляду на прекарне становище ув'язнених у тюрмах, така «квір-інвестиція в покарання», на думку авторки, лише сприятиме утвердженню нової форми сегрегації певних прошарків населення (за статистикою, це переважно люди кольору). Власне, про тюрми як місця багаторівневої маргіналізації людей кольору, людей, що живуть із ВІЛ, та трансгендерних людей розповідає дослідження Че Госсета. Стаття розглядає ув'язнення Греґорі Сміта за ймовірну спробу навмисного вбивства як приклад політики криміналізації та стигматизації людей із ВІЛ. Госсет також описує багатолітню боротьбу за кращі умови утримання та надання медичної допомоги ВІЛ-ув'язненим які, згідно зі статистикою, отримували довші тюремні терміни.

Дещо тематично іншою, втім методологічно цікавою з огляду на війну та мілітаризацію сучасного українського суспільства, є стаття Мi-

\footnotetext{
${ }^{2}$ В оригіналі “walking while transgender”. Формулювання перефразовує відомий у Північній Америці вислів «їздити в чорному стані» (“driving while black”, DWB), який є саркастичною реакцію на статистику частішого затримання людей кольору, що ведуть авто, без причини. Остання фраза також є перефразованим бюрократичним формулювання «їздити в нетверезому стані» (“driving while impaired” чи “driving while intoxicated”). «Їздити в чорному стані» стало змістоутворювальною фразою на позначення дискримінації, шовінізму чи ксенофобії. Також побутує формулювання (вжите й у збірнику) «літати у коричневому стані» ("flying while brown"), апелюючи до посилення нагляду в аеропортах за людьми кольору в межах «війни проти тероризму».
} 
шель Н. Мартін-Барон «(Гіпер/не)видимість і воєнні трупи» ${ }^{3}$. Авторка використовує квір як категорію аналізу для дослідження американської армії. Розглядаючи роль «побратимів по зброї» під час воєнних похоронів, вона підкреслює, що поряд із фактичною родиною товариші по службі є воєнною квір-сім'єю - «гомосоціальною мережею турботи». Квірність воєнного братства (як-от опіка над тілом загиблого, побратимські мікроритуали на похоронах), попри демонстративність, $\epsilon$ водночас невидимою, оскільки репрезентується через формалізований гетеронормативний маскулінний дискурс. Воєнні похорони мають також важливе символічне значення, оскільки через ритуал загиблий перетворюється на ідеалізований символ американської нації. Як зазначає авторка, таке некрополітичне перетворення «тіл, маркованих на смерть» [bodies marked for death] на «трупи ідеалізованих громадян», що начебто було призначені для життя, $є$ прикладом внутрішньої некрополітики американської «воєнної машини» (68). Важливо, що воно також є формою виправдання війни й вербування нових тіл на смерть.

Частина досліджень слушно звертає увагу на обмеження некрополітики як аналітичної парадигми. Справді, представлення певних вразливих квір-груп тільки як жертв неоліберальних режимів позбавляє їх суб'єктності. Приміром, стаття «Транс*фемінна цінність» Арен 3. Айзури демонструє парадоксальну ситуацію: незважаючи на те, що смерті транс*жінок-мігранток часто $є$ «неоплакуваними», їхні тіла та праця (включно з роботою в сексіндустрії) затребувані західною економікою (15). Ба більше, попри нерівне суспільне й економічне становище, вони відіграють важливу роль у забезпеченні економічного добробуту своїх родин у себе на батьківщині.

«Квір-некрополітика», безперечно, є важливим внеском у дослідження квір-спільнот завдяки критичному розгляду низки актуальних тем, починаючи від гомонаціоналізму, ВІЛ-криміналізації та мікроаналізу вразливих транс* спільнот кольору, й аж до досліджень міського ландшафту крізь квір-оптику. Різноманітність тем і застосування міждисциплінарних підходів робить збірник однаково цікавим для дослідни_ць, які давно займаються квір- і гендерними студіями, а також для всіх, хто прагне познайомитися з розмаїттям західної квір-історіографії. Більшість статей, однак, зосереджені на некрополітичних практиках неоліберальних урядів і гегемонних білих чоловічих гей-середовищ щодо транс*жінок і людей кольору. Такий фокус автури цілком виправданий хоч би з огляду на те, що насильство проти жінок перебуває в центрі уваги багатьох академічних досліджень, тоді як важке становище транс*жінок кольору не отримує належної уваги. Все-таки книжка збагатилася б, якби пояснила відмінності в некрополітичних практиках щодо

\footnotetext{
${ }^{3}$ Оригінальна назва статті “(Hyper/in)Visibility and the Military Corps(e)” має важливу неперекладну гру слів, що ілюструє аргумент авторки про військо як некрополітичний простір. Адже англійською “corps” означає рід військ, а “corpse” - труп.
} 
різних квір-спільнот. Наприклад, було би цікаво більше дізнатися, чим відрізняться маргіналізація транс*фемінних людей у чоловічих і жіночих гей- та гетероспільнотах.

Квір-середовища $є$ провідною темою дослідження книги, втім «Квір-некрополітика» може бути цінною для дослідни_ць 3 інших дисциплін, ба навіть для тих, хто не надто цікавиться квір- чи гендерними студіями. По суті, представлені статті - це прискіпливе аналітичне прочитання концепції некрополітики Мбембе як крізь призму воєн і зовнішньої політики, так і через аналіз повсякденних і рутинних практик. Відтак вчені, що досліджують війну з терором і збройні конфлікти, карцеральну систему, неоліберальну економіку, расизм і ксенофобію, знайдуть у книзі чимало актуальних прикладів. Врешті, збірник також важливий у контексті українського ЛҐБТ-активізму, адже звертає увагу на той факт, що боротьба за права та свободи не повинна створювати нові ієрархії і поглиблювати суспільну нерівність.

Батлер Джудіт. 2017. Фрейми війни. Чиї життя оплакують? Пер. з англ. Ю. Кравчук. Київ: Медуза.

Butler, Judith. 2006. Precarious life: The Powers of Mourning and Violence. New York: Verso.

Mbembé, Achille. 2003. "Necropolitics." Public Culture 15 (1): 11-40.

Puar, Jasbir K. 2007. Terrorist Assemblages: Homonationalism in Queer Times. Durham: Duke University Press.

Оксана Гусєва https://doi.org/10.52323/492391

\section{Жити феміністично}

Sara Ahmed. Living a Feminist Life. Durham and London: Duke University Press, 2017.

Д

ев'ята книга феміністки та незалежної дослідниці Сари Ахмед «Жити феміністично» наочно реалізує відоме феміністичне гасло «Особисте є політичним». «Жити феміністично» - текст, що діалоги з видатними теоретикинями фемінізму, приклади з фольклору, художньої літератури та кінематографу, а також роздуми про розвиток і перспективи феміністичного руху. Фемінізм у розумінні Ахмед - це багатогранне поняття, яке не обмежується феміністичною теорією чи політичним активізмом. Як пояснює авторка, фемінізм - це водночас і тривала практична робота, що втілює феміністичну теорію в життя, i набір інструментів для демонтажу патріархальних структур, і проєкт конструювання феміністичних просторів. Спираючись на рефлексивно-аналітичний підхід, авторка демонструє, що життя за принципами 
фемінізму, як і саме поняття фемінізму, полягає в постійному критичному ставленні до навколишньої дійсності та в порушенні гострих і часто незручних питань.

У першому розділі книги Ахмед розглядає низку процесів, які супроводжують формування феміністичної свідомості. Авторка зауважує, що фемінізм насамперед починається з розвитку відчуттів щодо себе, власного тіла та довкілля. Поштовхом до появи таких відчуттів може бути як уперше прочитана феміністична книга чи підтримка з боку іншої феміністки, так і травматичні події чи пережиті поневіряння. Axмед, народжена в родині англійської християнки та пакистанського мусульманина, ділиться історією свого шляху до фемінізму, який вона відкрила в розмовах зі своїми тітками, мусульманськими феміністками з Пакистану: «Мої пакистанські тітоньки навчили мене, що мій розум належить лише мені [...]; вони навчили мене відстоювати власну думку та виступати проти насилля й несправедливості» (c. 4-5). Ахмед наголошує, що шляхи до фемінізму можуть відрізнятися, але всі вони ведуть до виникнення феміністичної свідомості. Авторка порівнює відкриття фемінізму з натисканням на вмикач: «увімкнено» означає, що раніше не видимі структури - сексизм і расизм - набувають виразніших обрисів. Не помічати ці дискримінаційні структури стає неможливо, і феміністка щораз більше намагається привернути до них увагу інших.

Однією з ключових фігур у книзі Ахмед є так звана «феміністка-втіховбивця ${ }^{1} »$ [feminist killjoy]. Наважуючись відкрито говорити про сексизм і расизм, вона часто натикається на шквал критики з боку суспільства та постає в очах інших емоційною, імпульсивною, неврівноваженою та, зрештою, загрозливою. Відмовляючись усміхатися й удавати щастя, «феміністка-втіховбивця» робить своїх родичів, друзів, колег і знайомих нещасливими. Ахмед вважає, що щастя - це своєрідна емоційна праця, яку можна передати формулою «роби інших щасливими, вдаючи втіху власну» (с. 58). Відмова жити згідно з цією формулою є одним із кроків на шляху до фемінізму. Інша ключова фігура у книзі - «свавільна дівчина» [willful girl], яку авторка асоціює з героїнею казки братів Грімм «Свавільна дитина». У казці свавільна дитина, - імовірно, дівчинка, - не слухається матері та, накликавши на себе божий гнів, невдовзі помирає від хвороби. Після поховання рука дитини раптово піднімається догори, і лише після того, як мати б’є непокірну руку різкою, мертве тіло стає нерухомим. Піднята рука, на думку Ахмед, символізує спротив і непокору, а різка - механізм влади, що дисциплінує тіло та поведінку; сама казка $\epsilon$ «попередженням про наслідки небажання коритися» (с. 68). Відмовляючись мовчати про насилля та дискримінацію, виступаючи в опозиції до патріархальної системи, феміністка стає свавільною, себто «своє-вольною», отже, висловлює свою власну волю. А її піднята догори

${ }^{1}$ Дякуємо Каті Рудик за вдалий переклад терміну. 
рука, стиснута в кулак, як зазначає Ахмед, $є$ не лише символом боротьби жінок за свої права, а й знаком протесту: «Коли рука стискається у феміністичний кулак, вона приєднується до руху, до лісу рук» (с. 85).

У другому розділі «Жити феміністично» Ахмед ділиться своїм досвідом роботи 3 упровадженням політики різноманіття [diversity] у британських вишах. Авторка спирається на свою раніше опубліковану працю «Як бути залученими: расизм і різноманіття в інституційному житті» [“On Being Included: Racism and Diversity in Institutional Life”] та ділиться результатами розмов з людьми, які працюють у відповідних підрозділах університетів з питань різноманіття. Більшість з них описують свою роботу у вишах як зустріч із цегляною стіною. Стіни, як пояснює авторка, - це не що інакше, як освітні чи суспільні структури, яким важливіше підтвердити факт наявності документів про роботу 3 різноманіттям, аніж безпосередньо впроваджувати різноманіття у своїх щоденних практиках. Відповідно, коли фахів_чині з питань різноманіття намагаються трансформувати заклади, в яких працюють, вони часто наражаються на опір з боку адміністративної системи. Ахмед наголошує, що зіткнувшись із невидимими інституційними стінами, варто невпинно на них тиснути, адже «феміністична робота інколи означає й биття головою об цегляну стіну» (с. 110).

У третьому й останньому розділі йдеться про наслідки, які веде за собою рішення жити феміністично. Висловлюючи та відстоюючи свою позицію, феміністка неминуче усвідомлює, наскільки деякі речі крихкі. Їй часто доводиться розривати стосунки з оточенням, яке відмовляється сприймати ії вибір; їй важко знайти простір, де б її почули та зрозуміли; вона може відчути, що в неї ніби щось зламалося всередині. Такі переломні моменти, як стверджує Ахмед, відіграють важливу роль у становленні суб'єктності феміністки. Іноді вона робить вибір дистанціюватися від деструктивних впливів, зосередившись натомість на власному розвитку та самопочутті (як, наприклад, вчинила сама Ахмед, коли звільнилася з університету через неспроможність інституції вирішити проблему сексуальних домагань).

У висновках авторка пропонує «набір для виживання втіховбивці» [a killjoy survival kit] - поради щодо піклування про себе, свій стан і особистий розвиток, а також додає власний феміністичний маніфест, яким підсумовує головні ідеї книги. Продовжуючи традицію феміністичних і трансфеміністичних маніфестів Донни Гаравей, Валері Соланас, Сенді Стоун, Джулії Серано, Сьюзан Страйкер та інших, маніфест Ахмед закликає до дестабілізації патріархальної системи шляхом викриття дискримінації та насилля. Головні ідеї маніфесту Ахмед зосереджені навколо фігури «феміністки-втіховбивці», яка, діючи за принципами феміністичного життя, сама стає яскравим уособленням феміністичного маніфесту. Готовність жити за іншим сценарієм, долучитися до феміністичного руху та підтримувати інших феміністок, а також відмова вдавати 
радість, залишати інших у щасливому невіданні та належати до дискримінаційних структур - одні з основних принципів маніфесту Ахмед. Авторка, однак, наголошує, що поняття маніфесту не обмежується переліком певних принципів і заяв: «Життя також може бути маніфестом. Коли я читаю деякі книги з мого набору для виживання, я сприймаю їх як маніфест, як заклик до дії, як заклик до боротьби... Маніфест живе власним життям; маніфест - це піднята догори рука» (с. 256).

Книга «Жити феміністично» розрахована на читацькі кола, які починають знайомитися з ідеями фемінізму або бажають поглибити розуміння принципів феміністичного життя. Дискутуючи про фемінізм, Ахмед проявляє себе не лише як експертка з гендерної та феміністичної теорії, а і як талановита письменниця, що сміливо експериментує з мовою, значеннями та контекстами. Книга Ахмед написана у формі дружньої, бесіди, яка інтелектуально стимулює та по-справжньому надихає жити феміністично: активно висловлюватися проти сексизму та расизму, протидіяти дискримінаційним структурам і стати однією з «феміністок-втіховбивць», що «вбиваючи гарний настрій», роблять світ більш справедливим і безпечним.

Ганна Гнедкова

https://doi.org/10.52323/498151

\section{«Наші Дикі»: естетика та політика в музиці незалежної України}

Maria Sonevytsky. Wild Music: Sound and Sovereignty in Ukraine. Middletown: Wesleyan University Press, 2019.

Ілюстрована фотографіями з поїздок Україною, а також нотами пісень і скріншотами з аналізованих відео, монографія «Дика музика» $€$ результатом тривалого етномузикознавчого дослідження Марії Соневицької, професорки кафедри музики в Каліфорнійському університеті Берклі. Це дослідження почалося далекого 2004 року, коли Руслана Лижичко виборола для України перемогу на «Євробаченні» 3 піснею «Wild Dances». Натомість Україною Марія зацікавилась набагато раніше завдяки розповідям її родичів про батьківщину, з якої вони мусили виїхати до Північної Америки, тікаючи від Другої світової війни, та з першої подорожі авторки до України, яка збіглася в часі з проголошенням Незалежності: 24 серпня 1991 року. Саме пострадянський період у розвитку української етномузики встановлює часові рамки дослідження, виданого 2019 року.

Дослідниця наголошує, що музика не лише робить естетичний внесок у культуру, а й витворює «візії суверенності» [sovereignty imaginary], 
може транслювати не тільки бажання (наприклад, лібідальні), а й політичні вимоги. Важливим концептом, характерним для української музики, і зокрема етномузики, $\epsilon$ «дикість» [wildness] - полісемантичне слово, яке дістає дедалі більше нових переосмислень у різних історико-політичних і культурних контекстах.

Ці контексти віддзеркалені в п'яти розділах монографії. У першому розділі йдеться про поступову трансформацію значень слова «дикість» у творчості Руслани, яка, власне, побудувала на цьому слові свій музичний бренд. Ключовими етапами в історії розвитку цього бренду дослідниця вважає три пісні. Перша - «Знаю я», в якій «дикість» синонімічна природній невимушеності та «первозданності» Гуцульщини - свідома автоекзотизація українських «інших», яку більшість гуцулів і гуцулок, опитаних Марією Соневицькою, сприйняла несхвально, вважаючи, що їх асоціюють із некультурними «варварами». Друга така пісня - «Дикі танці», де на догоду європейському співочому конкурсу, крім фетишизації Гуцульщини, з'являється також сексуалізація образу «дикої» України, відображена в кітчевих костюмах, що відсилають і до амазонки, і до принцеси-воїтельки Ксени. Третя - «Дика Енергія» - в дусі трендового екоактивізму шукає самовідтворювану енергію, здатну подолати «кризу людських сердець». I знаходить ї̈ - дику, «шаманську» - в Україні, на що натякають костюми «інших» у відеокліпі, разюче подібні до тих, у яких гурт Руслани виступав на Євробаченні, закликаючи так Україну емансипуватися від «синтетичної» енергії, яку вона отримує з Росії. Дещо дивує, чому, аналізуючи численні інтерв'ю та інстаграм-дописи співачки, дослідниця обходить увагою, лише побіжно про неї згадуючи, книжку «Дика Енергія. Лана» Марії та Сергія Дяченків та не порівнює потрактування «дикої енергії» в літературному та музичному проєктах.

Другий розділ Марія Соневицька присвячує творчості «Dakh Daughters», а також ненавмисному політичному контексту, який раптово додався до їхньої «аполітичної» дореволюційної композиції «Рози/ Донбас», перетворивши їх із музичних гіпстерок на героїнь Революції гідності та реактуалізувавши в українській самосвідомості образи «берегині» та «бандерівки». Остання є прикметною також як український спосіб творчої протидії російському дискурсу про неонацистське та «бендерівське» збіговисько на Євромайдані: «бандерівець» та «бандерівка» іронічно запозичуються з ворожого дискурсу для самоозначення і стають джерелом революційної солідарності.

Третій розділ, у якому авторка розмежовує поняття фольклору та автентики, зосереджується на виконавцях, які пробують просувати на шоу «Голос країни» українську автентику: Олексій Заєць та Сусанна Карпенко. У фокусі Марії Соневицької не тільки вокал, який вона вивчала в Україні у професора Євгена Єфремова, а й монтаж відеовізитівок Олексія та Сусанни на каналі «1+1» і коментарі журі шоу до їхніх виступів. Задовольняючи потребу у відродженні українського архаїчного 
минулого, автентика виявляється «незручною» для шоу, надто «дикою» та «неприборканою», «незвичною», подекуди навіть «комічною», а тому від початку приреченою на програш у «Голосі країни».

Четвертий розділ вміщує в собі розмову із засновником радіо «Мейдан» на території Автономної Республіки Крим про історію виникнення окремої хвилі зі східною музикою як засобу консолідації кримськотатарського населення півострова, а також про перипетії існування «MeydanFM» під час анексії. Станція, яка запрацювала 2005 року, почала муляти російській пропаганді випадковою відсилкою до революції на Майдані назві за рік до того, тому 2015 року мусила «переселитися» до Києва. Російська окупація Криму підвищила рівень політичної ангажованості радіо, а також визначила вектор його самоідентифікації: радше проукраїнський, аніж проросійський, попри незадовільну довоєнну політику України стосовно національних меншин. Поряд із «MeydanFM» у цьому розділі проаналізована перемога Джамали на «Євробаченні-2016» з піснею «1944», яка нагадала про спільний простір колоніального минулого - злочини СРСР проти кримськотатарського населення зокрема й України загалом, - а також стала, згідно з низкою оглядів, політичним висловлюванням проти окупаційного режиму РФ на українських теренах. Пісня «1944», на думку Марії Соневицької, змінила «правила гри» на «Євробаченні», започаткованого 1956 року як аполітичне шоу для «дружнього змагання» країн на противагу збройним конфліктам Другої світової війни.

У п'ятому розділі дослідниця зосереджується на діяльності гурту «ДахаБраха», який, граючи у стилі «етнохаосу», здобув популярність не лише в Україні, а й за кордоном і свідомо використав цю популярність задля донесення української політичної позиції до світової аудиторії. Його музика своєю «дикістю» нівелює бінарні опозиції добра і зла, порядку й хаосу, палімпсестно змішуючи різні шари минулого та теперішнього, звільняючи в такий спосіб український історичний дискурс від влади розхитаних (пост)радянських наративів. Творчість «ДахиБрахи» та міжнародний резонанс навколо неї «провінціалізує» Росію і позбавляє її монополії на сенсопокладання; це, відповідно, уможливлює «депровінціалізацію» українського голосу для розповіді про власну історію. «Етнохаотична» музика здійснює спробу проблематизувати питання геополітичного вибору між Заходом і Сходом, підказуючи, що Україна не може ані повністю європеїзуватися, ані повністю зросійщитися: ця країна єдина тільки - і саме - у своїй «дикості».

Відповідно, «дику музику» можна визначити як таку, що стратегічно залучає до перформансу екзотичні тропи з метою створення політичного висловлювання. Свідомо відмовляючись від поняття «націоналізм» через негативні конотації, яких воно набуло як у проукраїнській, так і в проросійській пропаганді, Марія Соневицька говорить про «візії суверенності», які здатна створювати «дика музика». Ця музика запро- 
шує приєднатися до української версії «акустичного громадянства» [acoustic citizenship], яке поширюється далеко за територіальні кордони України, утворюючи відчуття солідарної єдності в усіх, хто її слухає. Дикість бунтує супроти як музичних, так і політичних обмежень, що їй намагаються накинути, підштовхуючи своїм викликом переглянути розуміння «політичного». У боротьбі за самоінтерпретацію «дика музика» підважує конвенційні сенси, реконцептуалізує минуле, переоцінює теперішнє й уявляє майбутнє - перетворює Дикість із маргіналізованої інакшості на джерело сили.

Поняття «акустичного громадянства», запропоноване дослідницею, видається виправданим і особливо плідним у контексті закликів «почути Донбас», які лунали з музичних і політичних сцен на початку російсько-української війни. Побіжно окресленими залишилися питання ціни, яку «інші» сплачують за вихід із маргінесів у центр уваги, а також тонкої межі, що відділяє стратегічне використання екзотизму від «шароварщини».

Додаткове запитання, відповідь на яке доцільно було би пошукати в майбутньому, спираючись на теоретичні підвалини цієї монографії, стосується того, як змінюється з часом сприйняття української музичної автентики у просторі громадської думки - навіть на матеріалі окремо взятого шоу «Голос країни». І чи існує в дискурсі сучасної української музики загалом - з огляду на нещодавній скандал із MARUV на Національному відборі на «Євробачення-2019» та, ширше, на суспільне засудження будь-якої мистецької колаборації з країною-окупантом тенденція до проблематизації ії політичної складової на тлі таких випробувань, як революція та війна. 


\section{About the Contributors}

Ганна Гнедкова - літературознавиця, перекладачка. Магістерка філології Києво-Могилянської академії та компаративістики Віденського університету. Перекладає з німецької та англійської мов для численних українських видавництв: «КМ-Букс», «Знання», «Видавництво Жупанського», «Новий Самокат», «Видавництво», «Віват» та «Видавництво Анетти Антоненко». Пише рецензії та огляди для сайтів «Читомо» та «Yakaboo».

Оксана Дудко - кандидатка історичних наук (2011), докторантка Університету Торонто та наукова співробітниця Центру міської історії у Львові. Сфера наукових зацікавлень: культурна та соціальна історія першої світової війни та Української революції, Українські Січові Стрільці, історія насильства, історія театру. Окрім досліджень, пише тексти для виставок, а також курує музейні та театральні проекти. Вибрані публікації: «Між національною та популярною культурою: театри в окупованому Львові (вересень 1914 року - червень 1915 року)», Україна модерна 23 (2016), 45-76; «Riflemen Art: Visualising "the Ukrainian War"» в Lidia Głuchowska and Vojtěch Lahoda (eds.) Nationalism and Cosmopolitanism in Avant-Garde and Modernism: The Impact of WW I, Prague: Artefactum (у друці). Живе між Торонто і Львовом.

Надія Чушак - освітянка, працює на кафедрі соціології національного університету «Києво-Могилянська академія» та в сфері неформальної освіти. Перекладачка.

Erzébet Barát is an Associate Professor of Linguistics and Gender Studies in the Institute of English and American Studies, University of Szeged, and at the Gender Studies Department, Central European University. She earned her Ph.D. in social linguistics at Lancaster University, the UK, in 2000. She is director of the Gender Studies specialization in the English Studies MA, University of Szeged, and founding editor-in-chief of TNTeF: Interdisciplinary Gender Studies (http://tntefjournal.hu), the only Hungarian peer-reviewed (e-)journal publishing feminist scholarship. Her major fields of research and teaching are critical studies of discourse with a focus on language ideologies, hate speech, and a social theory of meaning; the intersection of feminist and queer theory, with a particular interest in non-exclusionary relational models of identity and sexual citizenship; feminist studies of the media, especially the articulation of the gaze, and ethical representations of the suffering of the distant other.

Aia Beraia, MA in Gender Studies, Tbilisi State University (Georgia). Aia is currently a Ph.D. student at the interdisciplinary program Democracy, Human Rights and Religion - a joint program of Ilia State University (Georgia) 
and the Munster University (Germany). In addition to working as a researcher and lecturer, Aia has been involved in feminist and queer activism in Georgia for about five years. Currently, she is an activist of Tbilisi Pride, the initiative which was founded in 2019.

Rita Béres-Deák has a BA in Cultural Anthropology and got her Ph.D. in Gender Studies at the Central European University. After teaching one term at the Gender Studies Department of CEU, she is currently an independent researcher. She is actively involved in LGBTQ and human rights activism.

Anna Carastathis is a feminist political theorist and co-director of the Feminist Autonomous Centre for Research in Athens. In 2021 - 2023 she is a co-investigator on the TRANSCITY project researching "Space, Gender, and Transitions in Athens," based in the Department of Social Anthropology at Panteion University of Political and Social Sciences. Anna is the author of two books: Intersectionality: Origins, Contestations, Horizons (published by the University of Nebraska Press, 2016) and Reproducing Refugees: Photographì of a Crisis (co-authored with visual sociologist Myrto Tsilimpounidi, published by Rowman \& Littlefield International, 2020).

Ramona Dima holds a Ph.D. in cultural studies from the University of Bucharest with research on contemporary queer cultural products in Romania. She is currently a master student in migration studies at Malmö University. Whenever she takes a break from trying to understand and navigate the Nordic/ Swedish academia, she works together with her life partner Simona Dumitriu on different artistic and independent research projects.

Simona Dumitriu, Ph.D., works as an independent curator and organizer. Between 2018 and 2020 Simona was curator at Skånes konstförening gallery in Malmö. She has been the initiator and part of the collective that organized Platforma space in Bucharest (2011 - 2015), and part of the feminist group Local Goddesses (Bucharest, 2015 - 2017). Between 2009 - 2013 she taught at the National University of the Arts Bucharest. Together with Ramona Dima, they form the artistic and writing duo Simona\&Ramona (aka Claude\&Dersch).

Oksana Husieva is a Ph.D. candidate in the Department of Slavic and Eurasian Languages and Literatures at the University of Kansas. Her research focuses on twentieth-century Russian and Ukrainian literature and culture, women's and gender studies, testimonial narratives, autobiography studies, and Slavic folklore.

Vanya Mark Solovey studied linguistics in Moscow and was active in several feminist and lesbian activist initiatives. He is currently a doctoral student at the Center for Transdisciplinary Gender Studies, Humboldt 
(n) University of Berlin, and author of articles on the contemporary feminist movement in Russia. His interests are feminist movements, intersectional analysis, and post-/decolonial approaches to postsocialism.

Myrto Tsilimpounidi is a social researcher and photographer. Her research focuses on the interface between urbanism, culture, and innovative methodologies. Current projects explore the dual crisis of representation both the political crisis of loss of faith in representative democracy as well as arguments about the partial, time-bound, subjective frame of photographic representations. Another strand of her work engages with a queer feminist critique of the visual world. She is the author of Reproducing Refugees: Photographia of a Crisis (Roman \& Littlefield, forthcoming) and Sociology of Crisis: Visualising Urban Austerity (Routledge, 2017); and the editor of Street Art \& Graffiti: Reading, Writing \& Representing the City (Routledge, 2017) and Remapping Crisis: A Guide to Athens (Zero Books, 2014). Myrto is the codirector of the Feminist Autonomous Centre for Research (FAC Research) in Athens. 
H.

7:3.5.

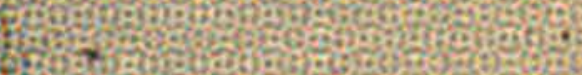
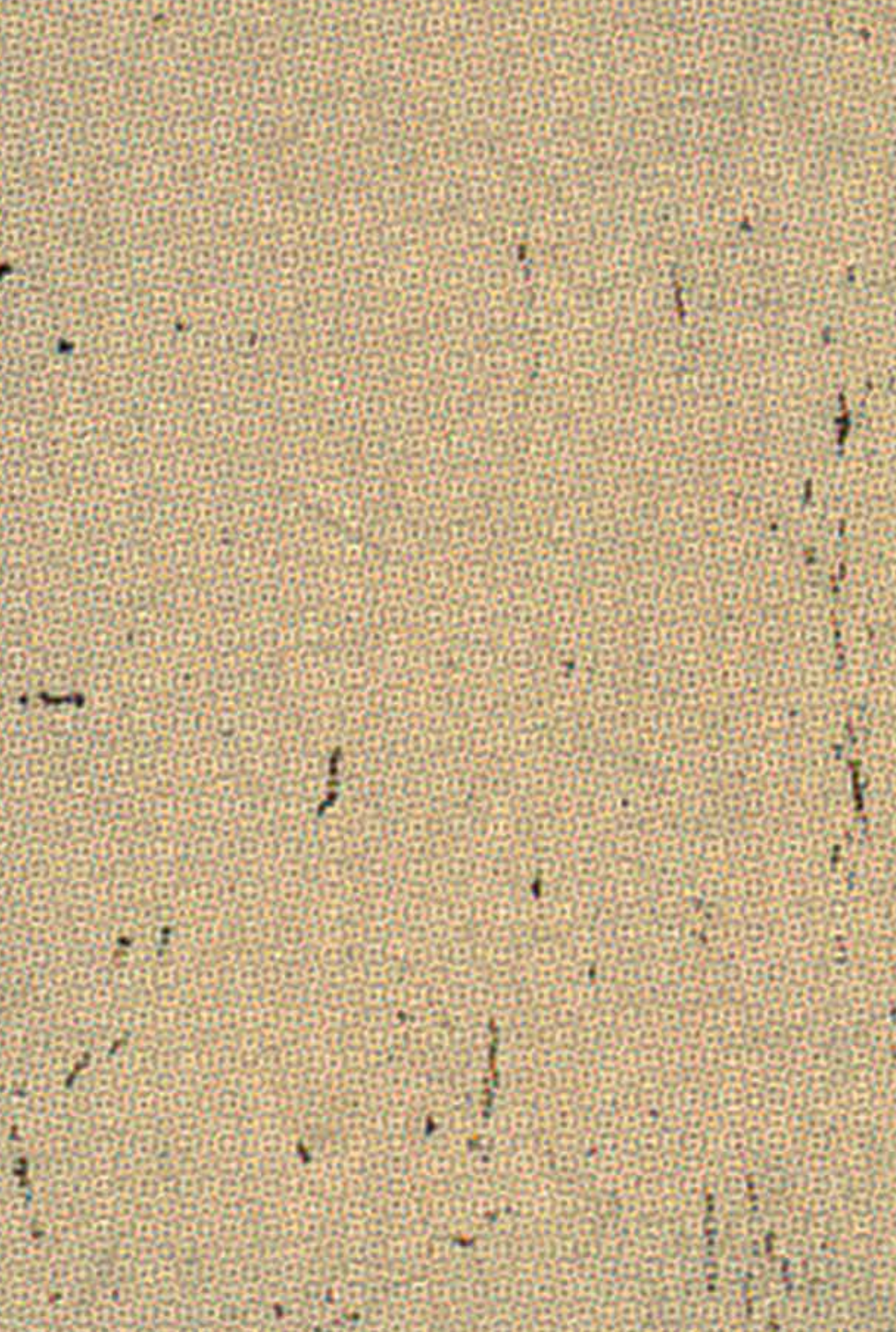